THE

\title{
FAUNA OF THE BATESTLLE SANDSTONE OF NORTHERN ARKANSAS
}

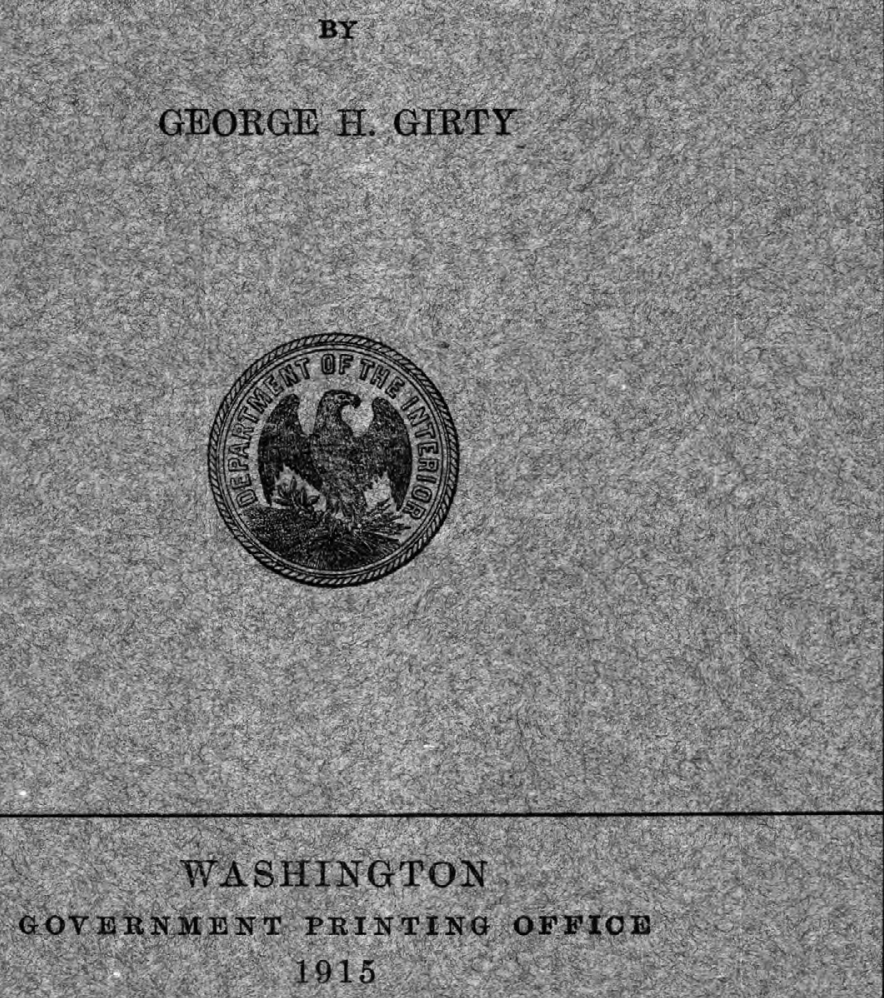


wher 
DEPARTMENT OF THE INTERIOR

UNITED STATES GEOLOGICAL SURVEY

GEORGE OTIS SMITH, DIRECTOR

BULLETIN 593

THE

\title{
FAUNA OF THE BATESVILLE SANDSTONE OF NORTHERN ARKANSAS
}

\author{
BY \\ GEORGE H. GIRTY
}

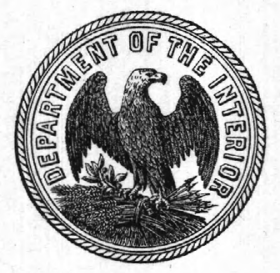

WASHINGTON

GOVERNMENT PRINTING OFFICE

1915 



\section{CONTENTS.}

The Batesville fauna and its relation to other faunas................ Page.

Description of species:

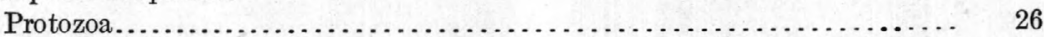

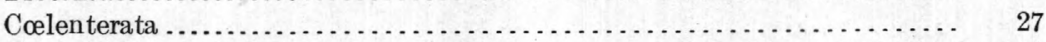

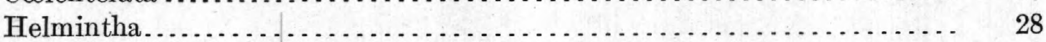

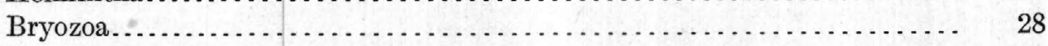

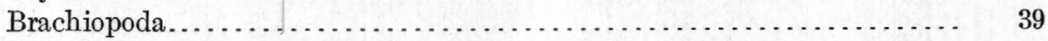

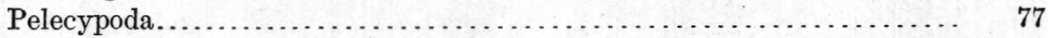

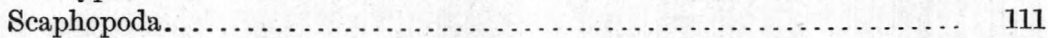

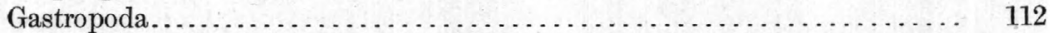

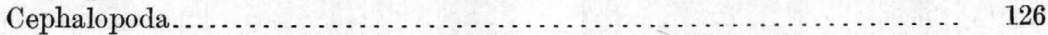

Trilobita...................................................... 133

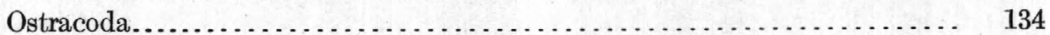

Register of localities........................................ 138

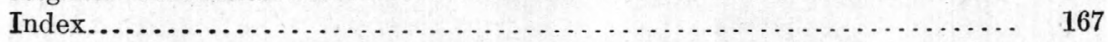

\section{ILLUSTRATIONS.}





\title{
THE FAUNA OF THE BATESVILLE SANDSTONE OF NORTHERN ARKANSAS.
}

\author{
By George H. Girty.
}

\section{THE BATESVILLE FAUNA AND ITS RELATION TO OTHER FAUNAS.}

The beds in northern Arkansas that lie between the Boone limestone (commonly regarded as representing the Burlington arrd Keokuk epochs) and the Pennsylvanian have been divided into sev.. eral formations, named, in ascending order, Moorefield shale, Batesville sandstone, Fayetteville shale, and Pitkin limestone. These formations presumably are equivalent to those that hold a corresponding position in the typical Mississippian section of Iowa, Missouri, and Illinois, but the faunas which they have furnished show noteworthy differences from the typical faunas. It has therefore seemed desirable to investigate these faunas, especially as the facies which they present is found also in the faunas of several of the Southern States, such as Oklahoma, Mississippi, and Alabama. With this object in view, I published in 1911 a report on the fossils of the Moorefield shale. ${ }^{1}$ The fauna next to be considered in a systematic pursuance of such a plan as I have mentioned is that of the Batesville sandstone, but the fauna of the Batesville sandstone, as is well known, has already been described in a treatise by Prof. Stuart Weller. ${ }^{2}$ At first I considered the possibility of pretermitting the Batesville fauna and of substituting Prof. Weller's report for my own in a series of little monographs that are under contemplation. It soon became evident, however, that this would not be satisfactory because, whether by reason of having collections from a number of new localities or by reason of having more extensive collections from old ones, I found that the material at my command considerably increased the number of types known from the Batesville sandstone, among them being a few which were undescribed. In fact, while Prof. Weller's paper discusses only 30 species (aside from a few Bryozoan types not even generically distinguished) the present

1 The fauna of the Moorefield shale of Arkansas: U. S. Geol. Survey Bull. 439, 1911.

2 Weller, Stuart, The Batesville sandstone of Arkansas: New York Acad. Sci. Trans., vol. 16, p. $252,1898$. 
paper discusses 128 species. On this account it seemed to me essential to redescribe the fauna.

In describing the upper Mississippian faunas of northern Arkansas I have found it desirable to treat the sections of the eastern as distinct from those of the western part of the State, this because both the formations and the faunas exhibit some important changes when traced from Independence County on the east to Washington County on the west. It was essential to adopt this course in regard to the fauna of the lowest formation because the Moorefield shale has been described as wedging out in passing westward, so that in Washington County it has completely disappeared, and the Batesville sandstone is mapped as resting directly on the Boone in the Fayetteville quadrangle.

The westernmost point at which the Moorefield shale, which is typically exposed in the Batesville region, has been recognized (or at least the westernmost point represented by fossils in the collections here considered) is at Marshall, in Searcy County, and my report on the Moorefield fauna was confined to collections from these two general regions, Batesville and Marshall. After careful consideration, it seemed best to limit this description of the Batesville fauna also to collections from the same territory. It is doubtless owing largely to the inclusion of these Marshall collections, as well as of collections from new localities in the Batesville quadrangle, that I have been able to add so many species to the list described by Prof. Weller, whose material came from two localities, from Ramsey Ferry, and also from Spring Creek, within a short distance of the town of Batesville.

Some of the fossils described in the present report were collected by Mr. E. O. Ulrich, but many others were afterward collected by me from the same and other localities. I have also availed myself of some small collections made earlier by Prof. Weller for the Federal Survey under the direction of Prof. H. S. Williams, which were discussed by Prof. Weller in his Batesville report, and, through his courtesy and that of the Walker Museum, I have been able to examine the types of some of the species he described from his own collections.

As this is an account of the Batesville sandstone, or rather the Batesville fauna, of only a particular region, it will not be desirable to include in the historical summary of the geology those references which deal with the formation in other regions, especially as, through miscorrelation, certain beds that lie west (as in Washington County) that have been described as Batesville sandstone, really constitute another and later formation. For this reason, though accounts by Simonds and Penrose appeared almost simultaneously in 1891, reference must be made to the description by Penrose, which is based on 
outcrops about Batesville, rather than to that by Simonds. The authentic description of the Batesville sandstone by Penrose ${ }^{1}$ may be quoted in full:

Overlying the Fayetteville shale is a sandstone formation with lenticular beds of gray, black, or brown shale. This formation lies on both sides of the White River, reaching to the area of the Fayetteville shale and the chert hills on the north, and on the south disappearing under the overlying rocks at the foot of the Boston Mountains. It is well developed at the town of Batesville and has been named by the State geologist the Batesville sandstone. It consists of a brown or buff-colored fine-grained sandstone, generally soft, though sometimes hard. It splits easily along the lines of bedding in slabs varying from a few inches to 3 or 4 feet in thickness and is extensively worked for structural purposes at Bartlett's quarry, in Batesville. The shales in the sandstone occur as lenticular deposits, often ending very abruptly, though sometimes traceable for several miles. They and the sandstones appear, in many places, to be mutually replaceable. The thickness of the Batesville sandstone is very changeable, varying from 20 or 30 feet to almost 200 feet. One mile east of the town of Batesville, on the bluffs of Blue Creek, it shows a thickness of 170 feet, and, as it is still at the foot of the bluffs, it is probably thicker.

In this citation, owing to the erroneous identification as Batesville of some sandstones that occur at the top of the Fayetteville shale in the Fayetteville region (instead of some sandy beds that occur at the base of the Fayetteville), the dark shale which was subsequently known as Moorefield, and which at Batesville underlies the Batesville sandstone, was called Fayetteville, and the shale above the Batesville, which really should be correlated with the Fayetteville, was called Marshall.

Subsequent publications add but little to knowledge of the formation that is pertinent to the present discussion, which does not consider the correlation of rocks in Washington County with those in other distant areas. It is perhaps worthy of remark that Williams ${ }^{2}$ states that the typical locality of the Batesville sandstone is at Ramsey Ferry. Adams ${ }^{3}$ first notes that at certain localities west of Batesville the formation contains interstratified limestones and that some of these have an oolitic phase. This conforms to my own observations, as will hereinafter be shown. Indeed, I found that the upper beds took on a calcareous phase only 10 miles west of that town. Penrose, as has been already shown, gives the Batesville in places a thickness of 170 feet, and Purdue states that at Batesville its thickness is somewhat over 100 feet. This thickness is much greater than that noted by me in any section in the Batesville region, but in none of them was the formation completely exposed.

\footnotetext{
${ }^{1}$ Penrose, R. A. F., jr., Arkansas Geol. Survey Ann. Rept. for 1890, vol, 1, p. 139, 1891.

${ }^{2}$ Williams, H. S., Arkansas Geol. Survey Ann. Rept. for 1892, vol, 5, p. 355, 1900.

${ }^{3}$ Adams, G. I., U. S. Geol. Survey Prof. Paper 24, p. 26, 1904.
} 
Prof. Weller ${ }^{1}$ subsequently described the character of the Batesville sandstone in the following terms:

The Batesville sandstone is an easily recognized formation at about the middle of the series, and it has been selected for a more detailed study, with special reference to its exact correlation with the formations of the typical Mississippian section. The formation is well developed in the region of Batesville, in Independence County, from which town it takes its name. It is a light-yellow or buff-colored rock, sometimes shading into a deep brown; finegrained and homogeneous in texture, generally hard and sometimes slightly micaceous. The greater portion of the formation is heavy bedded and hard, though it is more thinly bedded and softer near the base. It is used extensively for building purposes in Batesville, where there are large quarries. In some localities the sandstone is interbedded with lenticular layers of dark shale, which are sometimes of considerable extent.

Fossils are abundant in the lowermost, softer layers of the sandstone, but in the dense, higher beds they are entirely absent. The collections upon which the present study is based are from two localities. The first and most important locality is at Ramsey Ferry, about one-half mile southeast of Batesville. The fossiliferous beds found here are situated on the north bank of White River, just east of a small gully a few rods east of the ford. The greater number of species were secured from this place, where they oceur in the better state of preservation. The second locality is along the White River branch of the St. Louis, Iron Mountain \& Southern Railway, near Spring Creek, about 2 miles west of Batesville. At several points the railroad cuts into the sandstone. For half a mile the track is ballasted with the broken sandstone, and most of the fossils from the locality were secured from these broken masses.

I may say that I did not observe the included beds of black shale mentioned by both these authors nor the extreme thickness mentioned by Penrose.

The following are some of my own observations of the Batesville sandstone, especially at the points where the fossils described in this report were obtained. At Ramsey Ferry, on the north bank of White River, $1 \frac{1}{4}$ miles southeast of Batesville, neither the bottom nor the top of the formation was exposed when my observations were made. Indeed, as Prof. Weller's observations indicate that only the lower beds are fossiliferous, this exposure must comprise only the basal portion. About 30 feet of sandstone was seen. Of my own collection the only material actually in place came from the upper part of the outcrop, where the rock was hard whitish quartz sandstone. Most of my species were obtained from loose pieces, part of which had been quarried about half a mile below this outcrop and brought up for a dam then under construction. The upper beds were soft and powdery and are probably a weathered phase of the sandy limestone observed at Round Mountain, to which I shall refer later on. The several collections made at Ramsey Ferry are included in the table on pages 12-14, under No. 1234A4.

1 Weller, Stuart, The Batesville sandstone of Arkansas: New York Acad. Sci. Trans., vol. 16, p. $252,1898$. 
From this locality the Batesville, by actual outcrop or by large blocks that strew the surface at intervals, can be traced northeastward to Howards Wells (station 7700), where it overlies the black shales from which were obtained the fossils described in my report on the fauna of the Moorefield shale, and southward from that point to Moorefield, where it appears to rise above the Moorefield shale, but the outcrops seen did not furnish a favorable opportunity for measuring its thickness or for obtaining collections, though here and there scanty and poorly preserved fossils were observed.

It did not seem advisable to take time to study the geologic structure of the formations noted along the route, except in so far as it involved the horizon of the paleontologic collections. The formations were the Moorefield shale, the chert below (Boone?), and the sandstone above (Batesville). The stratigraphic relations of the cxposures indicated either faulting or sharp folding, more probably folding.

In the northeastern environs of Batesville is a large quarry, probably Bartlett's quarry, mentioned by Penrose. At this quarry and along the road farther south about 20 feet of whitish and reddish sandstones are exposed. Probably. as much as 100 feet of Moorefield shale here underlie it to water level. On the hill slope between the quarry and the wagon road a collection was made from loose blocks crowded with fossils (station 7699).

About one-half mile northeast of the depot at Batesville, along the railroad track, is a small quarry exposing about 30 feet of rock. The upper 20 feet are largely soft, thin, ferruginous beds separating irregular harder ledges, also thin. The lower part is composed of rather massive white sandstone in three ledges, about 4,3 , and 2 feet thick, respectively. In these rocks fossils are very scarce and no collection was made.

The Batesville is exposed also on the hill east of Spring Creek, a short distance northwest of Batesville. Here again the Moorefield shale is exposed below it. The sandstone is in place on top of the southern point of this hill but owing to its westerly dip descends with the hill slope very nearly to water level in the direction of the town. At this point, as elsewhere, no favorable place was found for measuring the formation, nor does it seem to be as fossiliferous here as it is farther east. From rock in place, loose pieces, and ballast along the railroad near by and probably almost in place, several collections were made (grouped under No. 1248D). This seems to have been the source of one of Prof. Weller's collections also, the other having been obtained at Ramsey Ferry. A small collection (1248B) is recorded as having been obtained beyond Spring Creek.

In the immediate vicinity of Batesville the strata exposed to view are the Batesville sandstone and the formation which lies be- 
neath it. At Round Mountain, 10 miles west of Batesville, it is possible to study the Batesville sandstone in its relation to the beds above. The wagon road, as it crosses the north face of Round Mountain, passes for the most part over the upper surface of the Batesville sandstone, which forms a bench. At the point where my observations were taken the Batesville is overlain by several hundred feet of black shale - the Fayetteville shale-and in the river bluff below 15 feet of sandstone are exposed. About 2 feet of the upper part of the Batesville here is a black sandy limestone. These beds do not occur in the black shale; they are not separated from the underlying sandstone but form a part of it. They are a mixture of calcareous sandstone and sandy limestone, the two grading into the sandstone below, which is a light-yellowish, rather fine quartz sandstone. From the upper calcareous beds I collected a group of fossils (No. 7089). The preservation here is much better than in the sandstone itself, which yields only molds.

So far as my observations go, the Batesville sandstone at Batesville is only 25 or 30 feet thick, the minimum measurement given by Penrose, but at no point where I saw it was the formation completely exposed.

The Batesville sandstone is well exposed in the vicinity of Marshall, forming, in fact, an extensive bench on which the town itself is spread out. The road leading west from the "Square" in Marshall soon passes down over the edge of this little plateau, exposing about 25 feet of sandstone which is rather highly fossiliferous (lots 7090 and 7587). The top is interstratified with red sandy shale, whose character is perhaps due to the solution of calcareous material. Beneath the sandstone is about 20 feet of black shale referred to the Moorefield.

A small ravine about one-half mile northeast of Marshall affords another opportunity to examine the formation. The Moorefield shale, here 35 feet thick, is succeeded by 25 feet of yellowish sandstone in thin beds, 1 foot of whitish calcareous sandstone, 3 feet of olive shale, 2 feet of fine gray fossiliferous limestone, and 5 feet of rusty shales and rusty sandstone. From the thick lower sandstone I collected the fossils of lot 7039a. From the overlying limestone lot 7092 was obtained.

At another locality a short distance beyond, about 1 mile east of Marshall, a collection was made under similar stratigraphic conditions. In a ravine cut by a small stream there occurs, above 20 feet of black Moorefield shale, 15 feet of fine, thin-bedded, somewhat calcareous sandstone, light bluish to yellowish in color, then a concealed interval of 10 feet, then 10 feet of massive calcareous sand- 
stone, above which is exposed 5 or 6 feet of fissile black shale. Along a road close by, from a nodular limestone whose position is above the thin-bedded sandstone but below the calcareous sandstone, I made the collection numbered 7092a. The nodules are brittle, earthy, and very fine textured and probably occur in a bed of shale.

A collection was made from probably the same horizon in a field $1 \frac{1}{2}$ miles southeast of Marshall. The stratigraphic relations are not entirely clear. Loose blocks of sandstone were found apparently almost in place at about the Batesville horizon and close by a poor outcrop of limestone fragments possibly representing a thickness of 5 feet. At this point lot 7091 was collected.

At the southeast end of Granny Mountain, 10 miles west of Marshall, what I take to be the same horizon was again encountered. In a trench near the main road on the McDaniel farm I found exposed about 20 feet of sandstone and dark limestone with black shale, and from a dark siliceous limestone at the bottom I collected iot 7093. The rocks here are chiefly limestone. The sandstone is fine and probably originally calcareous, in places rotten and ferruginous. Along the road, perhaps one-eighth mile south of this locality and at about the same horizon, I collected lot 7093a. The matrix is a siliceous and oolitic limestone. These strata appear to underlie the section of Granny Mountain (which consists of the black shale of the Fayetteville and of the overlying formations) and inferentially are underlain by the main arenaceous portion of the Batesville. At all events they come in essentially at the Batesville horizon, which was recognized in its proper relation to the Boone along the road between this locality and Marshall (7093b).

The following table shows the species which have been found in the Batesville sandstone and (in the last two columns) their distribution in the Batesville and Marshall quadrangles (indicated by the letters $B$ and $\mathbf{M})$. The numbers at the head of the columns are the designations of localities. (See register of localities, p. 138.) 


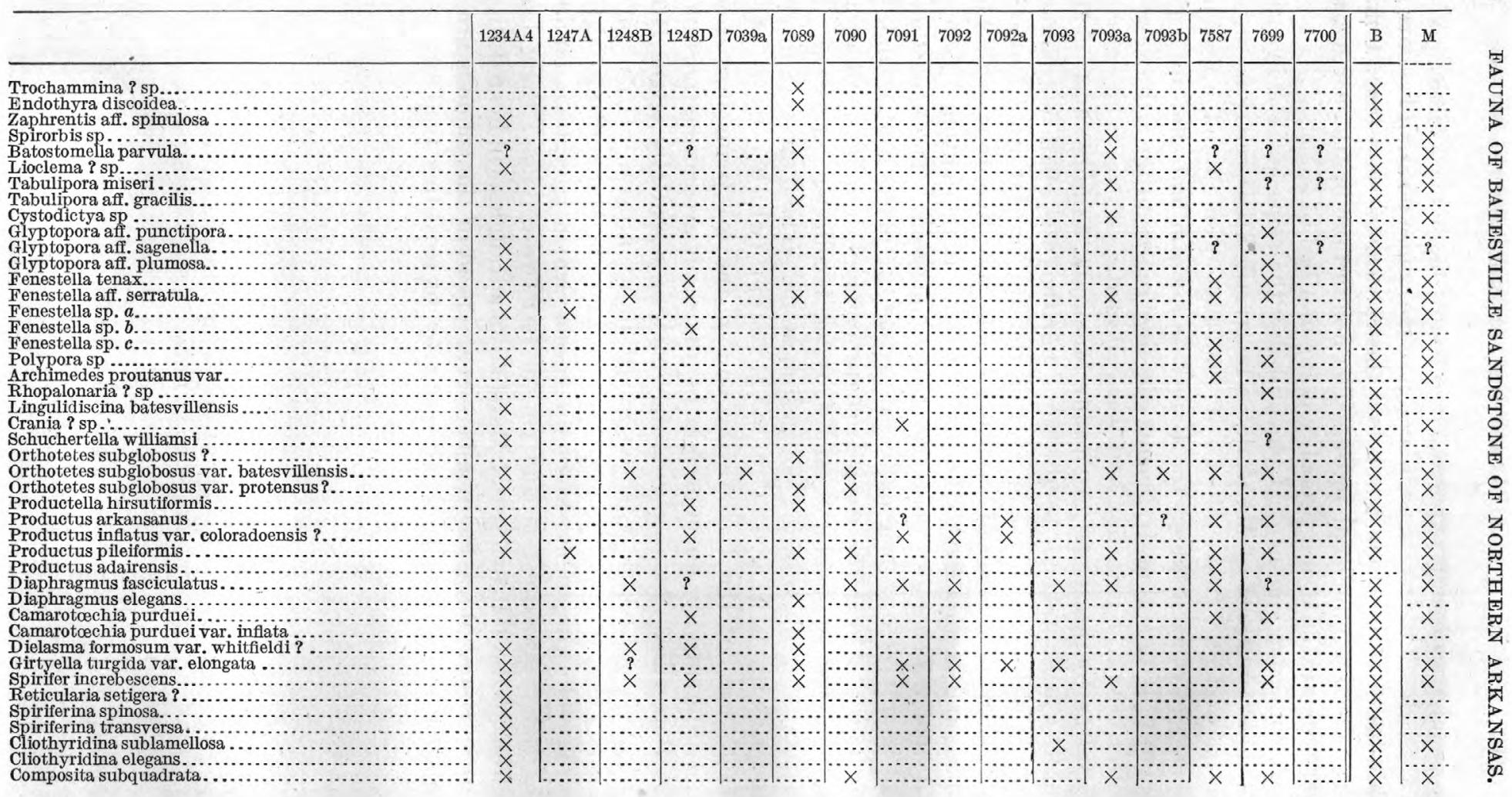


Composita acinus

Eumetria marcyi.

Sphenotus washingtonensis.

Sphenotus vulgaris.

Sphenotus aff. branneri.

Sphenotus cultellus

Sphenotus aff. meslerianus . . . . . . . . . . . . . . . . . . . . . . sphenotussp.

Edmondia equilateralis

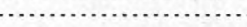

Edmondia crassa var. symmetrica.

Edmondia sp.

Nucula rectangula.

Nucula shumardiana.

Leda nuculiformis?

Yoldia levistriata?

Sulcatipinna arkansana

Leptodesma carboniferum

.

Conocardium cuneatum?

Caneyella hopkinsi

Myalina illinoisensis.

Myalina illinoisensis va...

Myalina monroensis... .

Myalina elongata

Schizodus batesvillensi

Schizodus depressus?

schizodus depressus var. abruptu.

Schizodus depressus var. circulus.

Schizodus brannerianus.

Deltopecten batesvillensis...

Deltopecten batesvillensis var.

Deltopecten batesvillensis var...

Deltopecten sp. $b$

Deltopecten sp.

Myoconche? g.

Lithophagus? batesviliensis

Allerisma maxvillen

Allerisma walkeri

Allerisma walkeri.....

Allerisma neglectum

Cypricardella oblonga...

Levidentalium venustum

Lepetopsis levettei?......

Pleurotomaria aff. perhumerosa

Pleurotomaria sp.
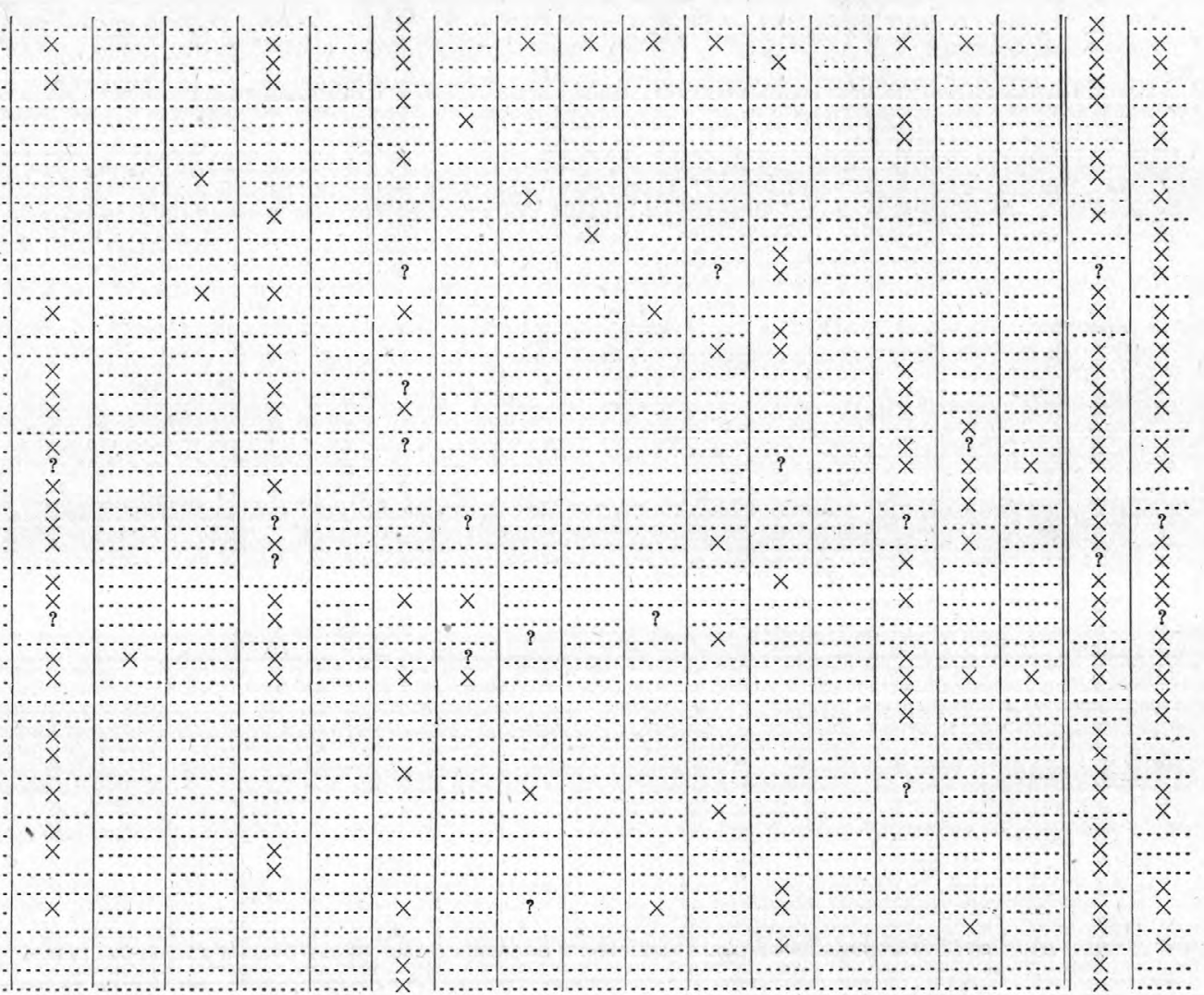


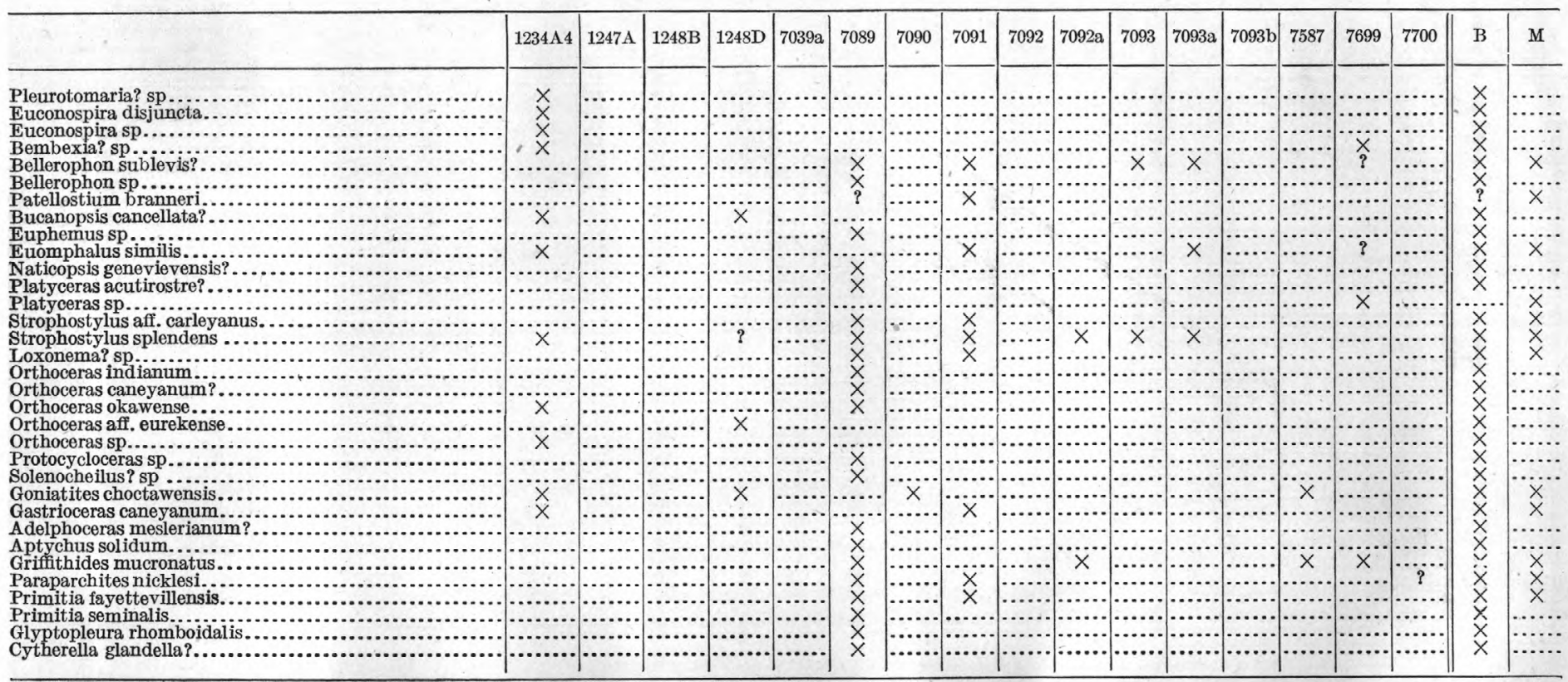


In addition to the invertebrate remains, which form the subject of the present paper and constitute nearly the entire organic development of Batesville time that is at present known, the Batesville sandstone has furnished a small number of vertebrate fossils, apparently the spines and scales of fishes, and also a few types which belong in the domain of paleobotany. The fossil plants were obtained only in the vicinity of Batesville at Ramsey Ferry and at Spring Creek. At Ramsey Ferry certain layers contain an abundance of what appear to be slender branches of a plant form which David White is disposed to refer to the genus Eskdalia. These stems have a width of 7 millimeters or less and are flattened to an elliptical section. They are simple or branched, the simple forms having parallel sides, the branched forms enlarging somewhat prior to bifurcation.

These stems comprise slender sandstone casts like the matrix, surrounded by thin coaly residues representing the partly decayed cortical tissues. They occur in direct association with Productus and other brachiopods. Somewhat similar looking but badly decayed fragments from another collection have no carbonaceous residue, the organic matter being replaced by brown iron oxide.

At Spring Creek the plant remains collected belong to the so-called fucoids, and as usual no carbonaceous material is present to show their woody nature. One type is a species of Taonurus which $\mathrm{Mr}$. White provisionally identifies as $T$. marginatus?. The botanic nature of the other type is more doubtful even than that of the Taonurus. It consists of parallel-sided curved axial casts having a diameter of 11 millimeters or less and compressed (?) to a thickness of about half that, which break out of the rock with only a plane of separation between themselves and the matrix, without any carbonaceous coating and without any markings whatsoever except possibly fine lines transversely directed.

A sandstone as fossiliferous as the Batesville is perhaps rather the exception than the rule, but there is little of intrinsic interest in the fauna itself, the general character of which is shown by the preceding table. The relative abundance of cephalopods is noteworthy but is to be expected at this horizon. The large pelecypod representation is rather natural to a sandstone fauna. The brachiopods are poorly represented in comparison with the usual Carboniferous faunal association, in which they frequently are the predominant and sometimes even the sole feature. In view of the conditions which must have obtained during the deposition of these sediments, it is perhaps noteworthy to find the Bryozoa so well represented. They are, however, rather fragmentary, a circumstance which suggests that they were transported from some more favorable area adjacent. Probably a much greater variety than the 15 species shown by my $49778^{\circ}-$ Bull. $593-15-2$ 
list could be obtained without much difficulty, but an identification of them would be at best unsatisfactory.

An inspection of the table (pp. 12-14) shows that the faunules of the Batesville sandstone, as developed in the Batesville and in the Marshall quadrangles, are very closely related to one another. Near Batesville no less than 109 species have been obtained and near Marshall 69, the difference in number probably being due, in part at least, to more complete collecting at the former locality. Of the Marshall species 50 occur also at Batesville, so that only 19 species found in the Marshall quadrangle are not known to occur in the Batesville quadrangle. A few differences in the characters of the two faunules merit comment. It is perhaps rather singular that the genus Glyptopora is chiefly confined to the Batesville area; so also is Spiriferina. As regards the Producti, immense numbers of $P$. pileiformis are found around Marshall, though the species is relatively rare in the Batesville quadrangle. On the other hand, Diaphragmus is much more abundant in the Batesville area. The brachiopod and pelecypod faunas are well developed in both areas and very similar, but the gastropod, cephalopod, and ostracode types are chiefly represented in the Batesville quadrangle.

It is rather surprising to find a faunal change so marked between the Batesville sandstone and the Moorefield shale immediately below. Up to the present 89 species have been recorded from the Moorefield shale, only 22 of them, so far as known, reappearing in the Batesville, where they constitute only about one-sixth of the whole. The Moorefield fauna is in many ways peculiar, whereas that of the Batesville shows fewer departures from the normal upper Mississippian assemblages and most of the peculiar Moorefield types are wanting to it. Thus the somewhat singular group of productoid species found in the Moorefield fauna fails to pass over into the Batesville sandstone. As a noteworthy exception Productella hirsutiformis, one of the most characteristic Moorefield brachiopods, has been found in small numbers. Two abundant and highly characteristic Moorefield types, Liorhynchus carboniferum and Moorefieldella eurekensis, are, so far as known, entirely lacking in the Batesville sandstone. One of these, however, L. carboniferum, recurs abundantly at Marshall in the overlying Fayetteville shale, suggesting the inference, already probable on more general grounds, that the change in facies of the Batesville fauna is due, partly at least, to environmental conditions. Other differences, perhaps rather less noteworthy, can readily be found by comparing the two faunas as tabulated in this and my other report, both among the brachiopods (such as the absence from the Batesville of Martinia and many other Moorefield Spirifers) the pelecypods, and the other mollusks. 
A resemblance, though accompanied by many differences, exists between the Batesville fauna and that of the overlying Fayetteville shale. The fauna of the Fayetteville shale is as yet unstudied except as it occurs at the very base of the formation in the Fayetteville region. The degree of relationship can not be stated numerically, even as regards the basal Fayetteville fauna, because my work on the latter is not yet completed. One at least of the most characteristic basal Fayetteville forms occurs in the Batesville sandstone, a single specimen of Productus adairensis having been found at Marshall, and some of the pelecypods are represented by identical or closely related species. On the whole, however, if the results of an uncompleted work may be so anticipated, the Batesville fauna seems to show differences from that occurring at the base of the Fayetteville shale rather more marked than would be expected from two faunas in such close geologic sequence. These differences may be in part regional, however, as the Batesville fossils at present under discussion came from the northeastern and the Fayetteville fossils from the northwestern part of the State. This element of geographic differentiation, on the other hand, can hardly enter into the relationship of the Batesville and Moorefield faunas discussed above, since the areas involved are the same in both cases.

I feel called upon in this place to discuss the correlation of the Batesville sandstone with the typical Mississippian section of southeastern Missouri and southern Illinois, though any conclusions reached must be of a very provisional character. Both faunally and lithologically the two sections show marked and important differences.

The Moorefield, Batesville, and Fayetteville interval has from the first been recognized as of upper Mississippian age. The difficulties multiply only when a more exact correlation of the formations is sought. The Arkansas Survey placed these beds, together with the overlying Pitkin limestone and other formations of their Boston group, as equivalent to the "St. Louis" and Chester groups of the Mississippi Valley. Clearly, then, the present formation would correspond to part of the "St. Louis" group, as that term has been long and loosely used. When discussing this fauna in 1898 Prof. Weller $^{1}$ stated his belief that it was definitely established on paleontologic and stratigraphic evidence that the Batesville sandstone was the equivalent of the "Aux Vases" (Cypress) sandstone of southern Illinois and southeastern Missouri. E. O. Ulrich ${ }^{2}$ on the other hand has suggested that the Batesville sandstone is really contemporaneous 
with the Cypress sandstone together with the underlying Ste. Genevieve limestone.

The typical upper Mississippian section and that of northern Arkansas under discussion occur on opposite sides of the Ozark uplift and are separated by a broad and unbroken expanse of preCarboniferous outcropping rocks. Around the western flank of this uplift the upper Mississippian is either missing altogether or represented by such small and scattered patches that its occurrence and stratigraphic relationship are unknown. Around the eastern flank, if continuous at all, the entire Carboniferous section is under cover, so that it is at present impossible, at least with the evidence at hand, to ascertain by means of stratigraphic tracing the relationship of the different members of these two sections. The only means available is their lithologic and paleontologic character and sequence.

The Moorefield, Batesville, and Fayetteville formations as a whole consist of black shale, with scarcely any limestone and but little sandstone save for the median formation which is the subject of discussion. Another exception should possibly be made of the Wedington sandstone of the Fayetteville quadrangle, if that sandstone is properly included as a member of the Fayetteville shale. The typical upper Mississippian section, on the other hand, consists largely of limestone, with but little sandstone and shale and scarcely any black shale. Thus a correlation by lithology of the two sections offers serious difficulties. The only considerable sandstone in the typical upper Mississippian section is the Cypress sandstone, which occurs in the middle of the Chester group, and with this sandstone Prof. Weller, as already mentioned, correlates the Batesville sandstone. There is also a much less important sandstone (the Rosiclare member) dividing the Ste. Genevieve limestone, which underlies the Cypress sandstone.

If the Batesville sandstone should be correlated with the Cypress sandstone, as Prof. Weller believes, the two overlying formations of Arkansas-the Fayetteville shale and the Pitkin limestone-would correspond to the Tribune limestone and Birdsville formation, respectively, of Kentucky, Illinois, and Missouri, the position of the massive limestone being reversed in the two sections. The Moorefield shale of Arkansas would correspond in position to the Ste. Genevieve limestone, though of course it is widely different in lithologic composition.

On the other hand, if we should attempt to correlate the Batesville with the Rosiclare sandstone member of the Ste. Genevieve limestone, the Moorefield and Fayetteville shales would answer in position to the oolitic Fredonia limestone member and the Ohara limestone member of the Ste. Genevieve. Now, nothing could be more unlike the white or light-colored oolitic Fredonia limestone than the black 
shales of the Moorefield. Fewer contrasts can be drawn between the Ohara and the Fayetteville, which does contain some inconsiderable limestone sheets. However, the Moorefield, Batesville, and Fayetteville formations impress me as forming a natural group of rocks distinguished alike from the heavy limestones of the Boone and Pitkin, between which they are contained. In its tripartite nature, as well as in the sandy character of the median formation, this series of rocks certainly suggests the Ste. Genevieve limestone in spite of the disagreement in other respects, as mentioned above. The overlying Pitkin limestone also stands comparison with the Tribune limestone.

In the present state of our knowledge the paleontologic evidence is hardly more satisfactory than the lithologic evidence in correlating the Batesville sandstone. Since almost no fossils are at present known from the Cypress sandstone and since the fauna of the Ste. Genevieve limestone has never been described, although Ulrich lists some of its species, a thorough discussion of this question from a paleontologic point of view is obviously precluded.

The difficulty of correlating the Batesville sandstone does not rest in this fact alone, that the faunas of some of the upper Mississippian horizons are imperfectly known; it is due also to the fact that our knowledge, imperfect as it is, seems to justify the assertion that the corresponding faunas of Arkansas show numerous and important differences. This is perhaps less true of the Batesville sandstone than of the Moorefield, Fayetteville, or Pitkin formations, yet even in the Batesville only about 25 per cent of the species are known in the typical Mississippian, even though we include among them doubtful identifications, and identifications written in the form of Glyptopora aff. plumosa, which may and in some cases very probably do cover species new to science. Furthermore, of the 31 or 32 species thus selected, some range through several horizons, and so are not characteristic of any one of them, while others, though seemingly associated in the Batesville sandstone, are not known to occur together elsewhere, so that their evidence is conflicting. Although but a fourth of the Batesville fauna is known in the typical Mississippian section, almost a half is known only in Arkansas and the adjacent region to the west and south. These facts only express general relations, and perhaps only temporary relations, but they are significant of the difficulties which attend a correlation of the Batesville sandstone at the present time.

As for Prof. Weller's correlation of the Batesville with the Cypress sandstone, the direct paleontologic evidence is not favorable. According to Ulrich, ${ }^{1}$ the fossils of the Cypress sandstone belong

${ }^{1}$ U. S. Geol. Survey Prof. Paper 36, p. 54, 1905. 
chiefly to one species, Pentremites godoni, which, however, is often very abundant. A small form of Zaphrentis spinulosa ranks next in abundance, while Cliothyridina sublamellosa and a species of Talarocrinus are also found. The Cliothyridina is the only one of these types known from the Batesville sandstone. Since, however, so many species of the Ste. Genevieve limestone occur again in the Tribune and Birdsville formations and must therefore have existed during Cypress time, this clearly can not be regarded as an expression of the real relationship between the faunas that flourished during the formation of these two sandstones.

If I provisionally adopt the correlation of the Batesville sandstone with the Cypress sandstone and Ste. Genevieve limestone, as first suggested by Prof. Weller and later amended by Mr. Ulrich, it is because the evidence does not indicate any different relations clearly, but it is also with the feeling that it does not indicate that relation as clearly as either of these authors seem to think.

Mr. Ulrich first correlated the Arkansas section in $1904,{ }^{1}$ but he did not at that time, nor in $1905,{ }^{2}$ nor recently in $1911,{ }^{3}$ offer any substantial evidence for correlating the Batesville sandstone with the Cypress and Ste. Genevieve formations. He does, indeed, state that some of the Batesville species occur in the Ste. Genevieve limestone, but he does not state how many they are nor what.

My own reasons for accepting this correlation until I have examined the Ste. Genevieve section and studied its fauna are as follows:

The entire absence of Pentremites and the all but entire absence of Archimedes, a genus which occurs in the Pitkin limestone in such abundance that it was for a long time known as the "Archimedes limestone," are very suggestive that we have in the Batesville a horizon older than the Birdsville, older even than the Tribune, of which Ulrich states that hand specimens, even of the oolitic limestones, usually contain examples of the characteristic Archimedes and Pentremites. The abundance of Glyptopora also, a genus which was developed chiefly in Keokuk, Warsaw, and St. Louis time, bespeaks a horizon earlier than the Tribune, possibly earlier than the Ste. Genevieve. Somewhat similar relations are indicated by the occurrence in a sandy limestone at the top of the Batesville of great numbers of Endothyra, a genus not known in the Mississippian, I believe, except in the Spergen limestone, but a genus which is easily overlooked. This is not the common Spergen species, however.

In its general make-up the Batesville fauna, with its highly differentiated pelecypod, gastropod, and cephalopod elements and

${ }^{3}$ Geol. Soc. America Bull., vol. 22, pl. 29, opp. p. 608, 1911. 
rather restricted brachiopod element, resembles the Spergen fauna, of which the main features, with many of the same species, persist through the Fredonia member and the Tribune limestone. Relatively few Spergen species, however, can be identified in the Batesville fauna, and there is for the most part a conspicuous absence of those minute forms, mostly of a Spergen facies and of an occurrence suggesting bionomic conditions which expressed themselves lithologically in the formation of oolites, such as are found in the Fredonia member of the Ste. Genevieve and in the Tribune limestone.

In most cases where such identifications have been made the Batesville forms are much larger than their representatives in the Spergen limestone. So far as these Spergen types are represented in the Batesville fauna they also indicate an age older than the Birdsville. There is, however, nothing about this Spergen element (except perhaps its smallness as a factor in the entire fauna) which would mark it as belonging particularly to Tribune, to Ste. Genevieve, or to Spergen time. On the other hand, the strictly Chester element would indicate an age at least as late as Ste. Genevieve, apparently as late as upper Ste. Genevieve.

It is instructive to make a specific comparison of the Batesville fauna with the table given by Mr. Ulrich to show the range of species in the Spergen, St. Louis, Fredonia, Ohara, and Tribune limestones of western Kentucky. Aside from a number of forms mentioned in the text and not here included, the table embraces 75 species. It is necessary to bear in mind of course that not all these species occur in any one of the faunas tabulated, and on the other hand that not one of the faunas is completely represented in the table. With the comparison conditioned in this way, and with much latitude allowed for identifications which indicate similar but probably not identical species, it appears that the Batesville fauna contains 22 species in common with Mr. Ulrich's table, representing only 29 per cent of the tabulated species and only about 17 per cent of the Batesville fauna. None of these 22 species is characteristic of any one of the faunas listed. The following table shows the 22 species to which I refer and their range in the different formations of the upper Mississippian in western Kentucky and southern Illinois. I have employed the names adopted in the present report and although some of them are recorded under different titles in $\mathrm{Mr}$. Ulrich's table, there will be no difficulty on the part of anyone familiar with the Carboniferous faunas in understanding what equivalents are intended. 
Fossils of the Batesville sandstone found also in the Spergen, St. Louis, Fredonia, Ohara, and Tribune or Birdsville limestones of western Kentucky.

\begin{tabular}{|c|c|c|c|c|c|}
\hline Species. & Spergen. & St. Louis. & Fredonia. & Ohara. & $\begin{array}{l}\text { Tribune } \\
\text { or Birds- } \\
\text { ville. }\end{array}$ \\
\hline 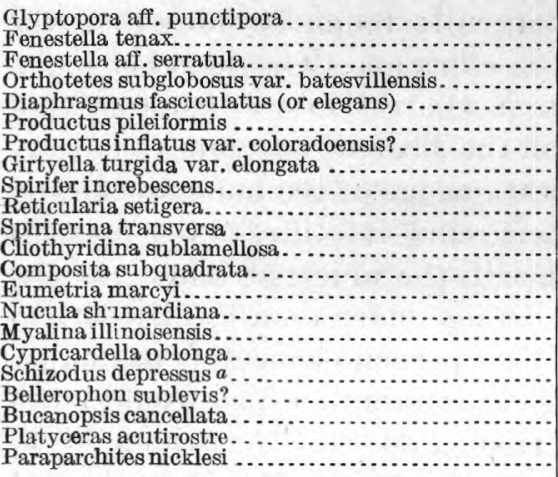 & 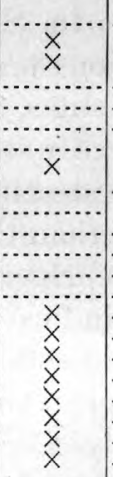 & 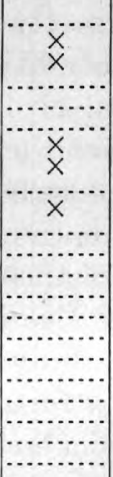 & 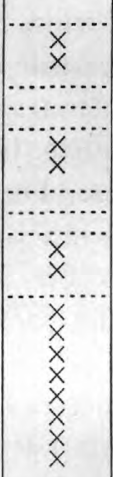 & 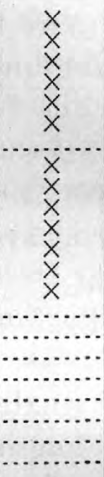 & 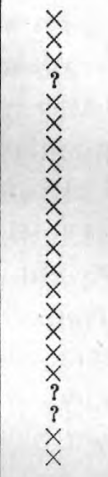 \\
\hline
\end{tabular}

$a \mathrm{Mr}$. Ulrich has Schizodus compressus, but as there is no species by that name I infer that he means depressus.

An analysis of the foregoing table indicates that so far as the bryozoa and brachiopods are concerned the affinities of the Batesville fauna are chiefly with the Ohara and Tribune members of the Ste. Genevieve limestone, though some of the species range down into the Fredonia member of the Ste. Genevieve and a few others down into the St. Louis limestone or even into the Spergen. If the pelecypods and gastropods are considered, however, the resemblance is uniformly with the Spergen, Fredonia, and Tribune or Birdsville, the Ohar:a being essentially a molluscoidean fauna. Only one pelecypod is cited from the Ohara limestone member. That one type, however, a species of Pteronites, is perhaps significant, since forms referred by Prof. Weller to Pteronites, though now believed to belong to Caneyella, are rather characteristic of the Batesville fauna, or at least of the Moorefield, Batesville, and Fayetteville faunas, for they occur in all three. The Tribune or Birdsville column is the only one which contains all the 22 species under consideration, but owing to the absence in the Batesville of many wpecies characteristic of those faunas, the indicated age of the Batesville is probably older than Tribune. But the mollusks indicate Spergen, Fredonia, and Tribune (or Birdsville) just as indifferently as the molluscoidea indicate Ohara and Tribune (or Birdsville). We may, however, assume the continuance of the molluskan species through the Ohara, whereas we may not assume the appearance of the molluscoidean species earlier than the formations shown in the table.

Of the Batesville species not found in the Fredonia member or below (as indicated by Mr. Ulrich's tables) one type which I regard 
as of special importance is the genus Diaphragmus, which abounds in the Batesville sandstone (it is found also in the Moorefield and Fayetteville shales) but which my own observations have not indicated as occurring in the Warsaw, in the St. Louis, or in the Ste. Genevieve limestone except in the Ohara member.

These facts indicate that the Batesville fauna is older than the Birdsville and probably older than the Tribune. On the other hand, they indicate that it is younger than the St. Louis limestone and probably younger than the Fredonia member of the Ste. Genevieve limestone. This last is indicated by the range of the brachiopods and bryozoa shown in the foregoing table and is contradicted to some extent by the other facts connected with the range, as known, of the Endothyra and Glyptopora, as already mentioned. This would strictly limit the Batesville to the Cypress sandstone and the upper member of the Ste. Genevieve (Ohara), though such refinement can not be insisted upon.

As against this, it seems to be true that though the Batesville fauna does, as Ulrich states, contain some species which occur in the Ste. Genevieve limestone, it presents numerous and important differences from the Ste. Genevieve fauna, at least so far as I have knowledge of the latter. It does not, for instance, contain any of the seven or eight species mentioned by Ulrich as strictly characteristic of the Ste. Genevieve. It also seems to contain a much smaller percentage of Spergen types than any of the typical faunas (except of course the Birdsville), less even than the Tribune. It may be noted in this connection that the Spergen horizon, or at least the pure Spergen fauna, is entirely unrepresented in the Arkansas section and the infusion of Spergen elements in any of the faunas is relatively slight.

Since the Batesville fauna shows affinities chiefly with the upper Ste. Genevieve, since it also shows many differences, and since the fauna of the Cypress is all but unknown, it may be that more complete information about the Cypress would lead to a correlation with that alone instead of with the combined Cypress and Ste. Genevieve.

If we could with certainty correlate the beds above and below the Batesville its position in the typical section would of necessity be determined, but unfortunately this is impossible. In the typical upper Mississippian section there is no fauna known which resembles the fauna of the Moorefield shale except very remotely. The most promising feature of the peculiar Moorefield fauna is its goniatites, a group which is usually considered of special value for correlation. Goniatites are rather rare in the rocks of the Mississippi and Ohio valleys, but forms more or less related to those of the Moorefield shale occur at horizons which have uniformly been identified as belonging to the "St. Louis" group. Unfortunately we do 
not know whether the horizon is really that of the St. Louis limestone or above or below it. Perhaps the most conspicuous of these occurrences is that at Crab Orchard, $\mathrm{Ky}$. According to the State report on Lincoln County, only the basal portion of the Mississippian limestone occurs in this county, and it is said to correspond to the St. Louis limestone of adjoining areas. It is probable that from this horizon the goniatites were obtained, although mention is not made of them and although mention is made of the casts of goniatites in the shales of the Waverly group below.

On the other hand, if my observations as to the range of Diaphragmus are correct, the Moorefield would apparently be younger than the St. Louis limestone. E. O. Ulrich in 1904 aligned the Moorefield with the St. Louis, but in 1911 he put it in an unrepresented interval between the St. Louis and the Ste. Genevieve.

This author seems equally inconstant in his views about the Fayetteville shale. In 1904 he was quite confident that the Fayetteville shale correlated in part with the "Kaskaskia limestone." He says:"

Many of these species are new to science, and the majority of these again are not known out of Arkansas. A large number, however, of both old and new species are recognized as forms marking the lower half of the Kaskaskia limestone division ( $i$. e., the middle part) of the Chester group of shales, sandstones, and limestones in Illinois and Kentucky. The writer, therefore, is satisfied that the Fayetteville formation represents that portion of the Chester age. This opinion is confirmed by the overlying Pitkin limestone, which he is equally confident represents an upper part of the Chester group of the Mississippi Valley. So far as observed by the writer, the fauna of the Pitkin agrees better with that of the upper limestone of the proposed Birdsville formation of the Chester than with any of the other divisions.

The only evidence offered in support of this conclusion is as follows:

In arriving at these conclusions chief reliance is placed upon certain undescribed Pelecypoda and species of Bryozoa, like Archimedes compactus Ulrich, A. communis Ulrich, and A. swallovanus Hall, which occur in the Fayetteville fauna, and in Kentucky and Illinois are restricted to the basal part of the Birdsville and to the underlying Tribune limestone.

In 1911, however, he refers the Fayetteville (along with the Pitkin) entirely to the Birdsville horizon, leaving no representative of the Tribune in the Arkansas section. With the Fayetteville shale as Tribune and the Moorefield shale as St. Louis, according to Mr. Ulrich's earlier views, the Batesville is clearly left, barring gaps, as the representative of the Cypress and Ste. Genevieve as he had it and still has it. But on the evidence of their own fossil faunas the correlation of the Moorefield and Fayetteville formations is, I believe, as uncertain as that of the Batesville itself. 
I have already stated that the Moorefield, Batesville, and Fayetteville formations impress me as being a natural group of rocks indicating somewhat closely related conditions of sedimentation and of animal life and set off against the limestone period of the Boone on the one hand and against the limestone period of the Pitkin on the other. If this view is correct it would militate against assigning the correlates of these formations in other sections to different stratigraphic groups and especially against assuming, as Ulrich has recently done, an interval between the Fayetteville and Batesville corresponding to the Tribune limestone of the typical section. On the other hand, the appearance in the Fayetteville of certain species of Archimedes, as noted by Ulrich, does suggest Tribune or Birdsville time. These species, however, are characteristic of the upper portion of the formation, the basal Fayetteville shale being almost as devoid of Archimedes and Pentremites, those characteristic Tribune and Birdsville types, as is the Batesville itself. This point I expect to discuss more at length and with more complete data in connection with the description of the fauna of the Fayetteville shale, which is now in progress.

- The Batesville fauna can hardly be discussed without some regard to the Moorefield fauna, which comes below, and the Fayetteville fauna, which comes above, and which contain species in common that are not yet known in the Batesville. It may be said therefore that the Batesville fauna, especially if taken in connection with the Moorefield and Fayetteville faunas, shows remarkable differences both from the Tribune and Birdsville faunas and from the Ste. Genevieve faunas, as far as they are known to me. On the whole the evidence at hand seems to favor a correlation of the Batesville sandstone with the Cypress sandstone together with the upper part or possibly the whole of the Ste. Genevieve limestone. If this is so, it seems clear that we have in the Moorefield, Batesville, and Fayetteville formations evidence of marked difference in sedimentation from that which conditioned the formation of the Ste. Genevieve, Tribune, and Birdsville formations, and that to these differences correspond others of a faunal character equally strong, such as the development of species in one area not found in the other and also more or less diversity in the time of appearance of species common to both. The facts at hand suggest that the Arkansas section belongs to a different faunal province from that of the typical section, at least so far as the upper Mississippian is concerned, and that it is inexpedient to combine the two in a standard time scale, as Mr. Ulrich has done in his revision of the Paleozoic systems.

July 29, 1912. 


\section{DESCRIPTION OF SPECIES.}

\section{PROTOZOA.}

\section{LITUOLIDA.}

TROCHAMMINA Parker and Jones.

Trochammina? sp.

Plate X, figures 17, 18.

The shells included in this group occur in association with Endothyra discoidea but are much less abundant. They are known only through the medium of thin sections. There they have a generally circular, though somewhat irregular outline, the average diameter being about 0.19 millimeter ( 0.14 to 0.197 or 0.21 millimeter). The different appearances presented probably result from a shell formed by a nearly cylindrical tube without constrictions or partitions coiled about itself irregularly so as to form a compressed or spheroidal ball. A tube coiled in the same plane but irregularly constricted or divided would, however, present the appearance of some of the sections. The inner diameter of a rather large tube is about 0.02 millimeter.

The walls appear to be uniform and dense in structure.

The genus Trochammina has not been heretofore identified in the Carboniferous of North America, but there is no reason to believe that it would not be found here if the more minute organisms were sought for and studied with the same zeal as in Europe. It is not certain, however, that the present form actually belongs to that genus, in which the shell is typically composed of cemented sand grains. The shell structure in the Arkansas specimens is not perhaps very well shown, but they do not show any evidence of such composition. On the other hand, the general structure appears to be almost exactly like that of Trochammina.

Trochammina? sp. is much smaller than most of the English Carboniferous species described by Brady. ${ }^{1}$ There are, however, two with which a comparison in size may be made, $T$. annularis and $T$. robertsoni. The structure, however, is more like that of one of the larger species, $T$. gordialis.

Horizon and locality.-Batesville sandstone, Batesville quadrangle, Round Mountain (station 7089).

1 Brady, H. B., Monograph of Carboniferous and Permian Foraminifera, pp. 71 et seq., Paleontographical Society, 1876. 


\section{ROTALIID $A$.}

ENDOTHYRA Phillips.

Endothyra discoidea n. sp.

Plate $\mathrm{X}$, figures 11-16.

Shell lenticular, very small, usually less than one-third millimeter in diameter. Thickness usually less than one-half the diameter. Nearly complanate, consisting of two or three volutions composed of rather large chambers, of which six or seven occur in the last volution. Walls of the final volution about 0.02 millimeter thick. Different sections, apparently perpendicular to the plane of revolution, measure 0.31 by 0.13 millimeter; 0.3 by 0.14 millimeter; 0.24 by 0.1 millimeter; 0.21 by 0.084 millimeter; 0.27 by 0.11 millimeter. A large section in the plane of revolution has a diameter of 0.38 millimeter.

This species is distinguished from E. baileyi, many specimens of which attain a diameter of 1 millimeter, by its smaller size, more discoidal shape and longer chambers, fewer of which form a volution.

Endothyra discoidea is rather common at Round Mountain, west of Batesville, the only locality where it has been found. It is known only in thin sections made from the black sandy limestone which there occurs at the top of the formation. It has not been seen on rock surfaces.

Horizon and locality.-Batesville sandstone, Batesville quadrangle, Round Mountain (station 7089).

\section{CGELENTERATA.}

\section{ZAPHRENTID $\boldsymbol{A}$.}

\section{ZAPHRENTIS Rafinesque.}

\section{Zaphrentis aff. spinulosa Milne-Edwards and Haime. ${ }^{1}$}

- This form is represented by a single specimen preserved as a mold in sandstone and much crushed. It is therefore impossible to give a complete description of it, but a few characters can be mentioned. The diameter is perhaps 20 millimeters and the length 35 millimeters. The septa appear to number about 28 or 30 , and in the calyce small secondary septa were developed.

Horizon and locality.-Batesville sandstone, Batesville quadrangle, Ramsey Ferry (station 1234A4).

${ }_{1}^{1}$ Milne-Edwards, Henri, and Haime, Jules, Monographie des polypiers fossiles des terrains palæozoïques, p. 334, pl. 5, figs. 7, 7a, 1851. 


\section{HELMINTHA.}

\section{SPIRORBIS Daudin.}

\section{SPIRopBis sp.}

At Granny Mountain, west of Marshall (station 7093a), a fragment of a shell, apparently part of a Myalina, retains an impression of a small spiral organism, doubtless a species of Spirorbis. It is only about 1.5 millimeters in diameter, and its surface characters are not known. The opening of the shell was clearly to the right, and as it must have been attached by the apex its coil was sinistral when placed in the position of a gastropod, with the apex uppermost.

Horizon and locality.-Batesville sandstone, Marshall quadrangle, Granny Mountain (station 7093a).

\section{BRYOZOA.}

\section{BATOSTOMELLIDA.}

\section{BATOSTOMELLA Ulrich.}

\section{Batostomella parvola Girty.}

1910. Batostomella parvula. Girty, New York Acad. Sci. Annals, vol. 20, No. 3, pt. 2, p. 191.

Basal Fayetteville shale: Fayetteville quadrangle, Ark.

1911. Batostomella parvula. Girty, U. S. Geol. Survey Bull. 439, p. 30, pl. 9, fig. 1.

Moorefield shale: Batesville quadrangle, Ark.

This species is represented partly by a few testiferous specimens from the sandy limestones of the upper part of the Batesville sandstone (station 7089) and partly by much more abundant molds in the sandstone beds themselves. It is not, of course, certain that the external molds are correctly united with the testiferous specimens under the species named. The testiferous material is both rare and very fragmentary, and it has not been possible to prepare thin sections adequate to a proper study.

The best slide shows a longitudinal and a tangential section made from different fragments which, however, possibly originated in the same zoarium. The longitudinal section shows a stem about 3 millimeters in diameter. The cells are longitudinal or slightly oblique and are straight or slightly flexuous in the median portion, bending rather abruptly outward when close to the surface, to which they have a perpendicular or slightly oblique direction. The walls in the radial or mature portion are rather abruptly and strongly thickened, but not moniliform. A few diaphragms irregularly arranged are developed in most of the cells just before they bend outward. The diaphragms appear to be nonperforate. 
The tangential section is less satisfactory than the longitudinal. The walls in the mature zone are thinner than in the longitudinal section, but they are sufficiently thickened at their junction to give the zoœcia a subcircular shape. The zoøcia themselves differ considerably in size, and a few of very small dimensions may be regarded as mesopores. Many of the cell angles are occupied by acanthopores of moderate size, and not uncommonly an acanthopore may be observed midway on the side. According to the size of the acanthopores and the thickness of the walls, the acanthopores do or do not indent the cells. The cells are slightly elongated and six or six and one-half occur in 2 millimeters longitudinally.

Of the other slides, one was made from material from the same locality as that just described. It shows not very satisfactory tangential and transverse sections of the same specimen, which agree with the above, save that the walls in the mature region are less thickened than in the longitudinal section.

I have also a poor longitudinal section which shows the mature zone very imperfectly discriminated, with the walls not much thicker than in the immature region and directed very obliquely to the surface.

A small segment of a stem and two of its branches has been obtained from Granny Mountain, in the Marshall quadrangle (station 7093a). No section has been prepared of this specimen, but macroscopically the cells appear rounded and elongated, with rather thick walls. Fairly stout acanthopores occur in the cell angles. On other parts of the surface, however, the walls are very much thinner and the fairly large acanthopores indent the cells.

This exhausts the testiferous material which I have been able to examine. The specimens in the sandstone, as already noted, are rather abundant, but they are preserved as molds. These specimens, of course, show little or nothing of the finer structures, but afford interesting data as to the mode of growth, a feature hardly shown at all by the very fragmentary material from the limestone. The sandstone specimens branch profusely and irregularly. Generally the branch is bifurcate, but a few stems divide into three or more branches. One peculiar specimen shows a somewhat massive basal (?) portion, $17+$ millimeters long, 8 millimeters across, and 5 millimeters high, from which proceed at least nine of the normal slender cylindrical branches. In another specimen frequent branching seems to produce a bushy growth, and some of the branches appear to coalesce. Similar peculiarities of growth are found in the original material of $B$. parvuta. The usual thickness of the branches seems to be about 2 millimeters, but at the point of bifurcation, and especially where the stem divides more numerously, the diameter is very much increased. 
There seems to be no satisfactory evidence for considering this material to represent more than one species, and it also seems probable that the species is $B$. parvula.

Horizon and locality.-Batesville sandstone, Batesville quadrangle, Ramsey Ferry (station 1234A4?), Spring Creek (station 1248D?), Round Mountain (station 7089), Sharps Crossroads (station 7700?), Batesville (station 7699?); Marshall quadrangle, Marshall (station 7587?), Granny Mountain (station 7093a).

\section{LIOCLEMA Ulrich.}

\section{Liochema? sp.}

The striking feature of this form consists in the presence of numerous small, very prominent monticules 2 millimeters or a little less apart. As these specimens are preserved as molds in sandstone, they do not show the character of the cell apertures, and though squeezes made from them have a finely pitted or apparently celluliferous surface, no trustworthy idea of the real structure is obtainable. In one specimen the growth is clearly incrusting, and this is probably the condition of all the others. Some appearances suggest that these growths may have given rise to slender branches, but this is not certain.

The generic position of this form is of course undetermined. The size of the zoocia, which are comparable to those of the form referred to Batostomella parvula, is rather small for Tabulipora (Stenopora).

Horizon and locality.-Batesville sandstone, Batesville quadrangle, Ramsey Ferry (station 1234A4); Marshall quadrangle, Marshall (station 7587).

\section{TABULIPORA Young.}

A recent work by G. W. Lee on British Carboniferous Trepostomata $^{1}$ calls attention to the fact that in typical Stenopora the diaphragms are complete, although in current usage the name is applied to species having perforated diaphragms only, and he proposes to revive Young's genus Tabulipora, which has usually been considered a synonym for Stenopora, to receive those species in which the diaphragms are perforated. This necessitates the removal of all our American Stenoporas to Tabulipora. Apparently there are no forms in the American Carboniferous which should be referred to Stenopora as now understood, unless it should prove that Batostomella was the same genus. Ulrich describes Batostomella as having originally perforated diaphragms, and thin sections seldom if ever show a perforated condition. For this reason Lee's removal of

${ }^{1}$ Lee, G. W., Geol. Survey Great Britain Mem., Paleontology, vol. 1, pt. 3, p. 147, 1912. 
Stenopora to the Amplexoporidæ because of its imperforate diaphragms seems rather inadvisable. If necessary to make some rearrangement of the genera, it would appear preferable to remove not Stenopora but Tabulipora to another family.

\section{Tabulipora miseri Girty.}

1910. Stenopora miseri. Girty, New York Acad. Sci. Annals, vol. 20, No. 3, pt. 2, p. 196.

Basal Fayetteville shale: Fayetteville quadrangle, Ark.

This identification rests chiefly on a very thin, somewhat contorted expansion not much over 0.5 millimeter in thickness and only about 20 millimeters in greatest diameter. The specimen has not been studied by thin section, the following data being derived from an examination of the upper surface, which is rather well preserved.

The zoœcia are thin-walled and angular, or thick-walled and rounded, and they differ considerably in size, but as a rule about six occur in a distance of 2 millimeters. Mesopores are rare. As already indicated there are groups of cells with thick walls and other groups with thin walls. There are also groups of cells larger than the rest, but there seems to be no correspondence between groups of the two categories. The difference in thickness of the walls is doubtless due to annulations, suggestions of which are found on the broken edges of the colony. It is a little uncertain whether normal spinelike acanthopores are present. No traces as a rule can be observed, and the projection of the angles of a few cells above the rest of the surface may probably be accounted for by the breaking away of the walls at the sides. Many cells show centrally perforated diaphragms, but from the extreme thinness of the zoarium there would hardly be more than one or two of these structures to a cell.

The characters observed indicate a relationship to $T$. miseri and possibly the specimen belongs to that species, but the data are insufficient to establish the identification.

Horizon and locality.-Batesville sandstone, Batesville quadrangle, Round Mountain (station 7089), Sharps Crossroads (station 7700?), Batesville (station 7699?) ; Marshall quadrangle, Granny Mountain (station 7093a).

\section{TABulipora aff. graciLIs Girty. ${ }^{1}$}

This species is represented by a small fragment from which it has been possible to make only a longitudinal and a tangential section, neither very satisfactory. The mode of growth is that of a slender cylindrical stem having a diameter of 2 to 2.5 millimeters. The mature zone, in which the cells have a radial direction, is very long:

${ }^{1}$ Girty, G. H., New York Acad. Sci. Annals, vol. 20, No. 3, pt. 2, p. 198, 1910. $49778^{\circ}-$ Bull. $593-15-3$ 
for the size but not well defined. In this region the walls are either continuously and only slightly thickened or expanded toward the surface into one or possibly two abrupt moniliform swellings. Diaphragms are moderately abundant, one to three to a tube and two diameters apart, more or less. The very small tangential section shows that the walls are rather thin, but thickened a good deal at the cell angles, so that the cells are subcircular in section. Mesopores (young cells?) are rather abundant, occurring in groups of two or three among the larger ones. Acanthopores are also rather abundant and rather large, situated in the angles where they do not or in the side walls where they do indent the cells. About six apertures occur in a space of 2 millimeters.

This form appears to be related to $T$. gracilis, but it is too imperfectly known for accurate determination. In spite of the small size of the stem the generic relations seem to be with Tabulipora rather than with Batostomella.

Horizon and locality.-Batesville sandstone, Batesville quadrangle, Round Mountain (station 7089).

\section{CYSTODICTYONIDA.}

CYSTODICTYA Ulrich.

Cystodictya? sp.

This is a mere fragment which appears to be bifoliate and is about 0.5 millimeter thick. Its generic position is uncertain. If a Cystodictya, its large size and irregular shape would indicate that it came from a point near the bifurcation of a frond. It might be a Dichotrypa, which genus does not elsewhere appear in the collection, or a Glyptopora, which is rather abundant.

Horizon and locality.-Batesville sandstone, Marshall quadrangle, Granny Mountain (station 7093a).

\section{GLYPTOPORA Ulrich.}

\section{GLYPTOPORA aff. PUNCTIPORA Ulrich. ${ }^{1}$}

This species is fairly common at locality 7699 , in the town of Batesville, where it occurs as flat or slightly undulating fragments, the largest of which has a diameter of 30 millimeters. These fragments apparently represent, as specimens of $G$. keyserlingi commonly do, pieces of the sides of the deep polygonal cups characteristic of the genus, which in this case must have been of large size. The most conspicuous feature of well-preserved specimens is the elongated maculæ, which are smaller and more closely arranged than in typical keyserlingi. The finer characters of the surface and of the

1. Ulrich, E. O., Illinois Geol, Survey, vol. 8, p. 519, pl. 78, figs. 9, 9a, 1890, 
zoøcia can not of course be made out from these sandstone molds, in which form the specimens are preserved. Though suggesting $G$. keyserling in many respects, the smaller and more closely arranged maculæ indicate that we have here a distinct species, which with better preserved material would show additional characters of discrimination.

$G$. punctipora, which is said to differ from $G$. elegans and $G$. keyserling $i$ chiefly in that the maculæ are smaller and very little impressed, is perhaps nearer, for the maculæ, so far as can be determined from this style of preservation, are about on a level with the rest of the surface. The minute characters that also distinguish typical punctipora can not be observed in my specimens, but their zoœcial apertures are apparently more closely arranged, often less than a diameter instead of a diameter and a half apart.

Horizon and locality.-Batesville sandstone, Batesville quadrangle, Batesville (station 7699).

\section{Glyptopora aff. sagenella Prout. ${ }^{1}$}

This species is not rare at Ramsey Ferry, near Batesville, the specimens being preserved as impressions in rather coarse friable sandstone. They are probably fragmentary, the largest having a diameter of about 35 millimeters. They are distinguished by numerous irregularities of surface, folds or ridges or both, which by uniting form numerous rather small cups, some of them of considerable depth. No specimen shows unequivocal evidence of maculæ. The cuplike formations differ greatly in size and in the completeness of their development, and a graduation into the type here cited as $G$. aff. plumosa is suggested by them. Some specimens much resemble typical $G$. sagenella, but perhaps the majority, owing to the larger size of the cups, might be referred to the variety lata.

Horizon and locality.-Batesville sandstone, Batesville quadrangle, Ramsey Ferry (station 1234A4), Sharps Crossroads (station 7700 ?) ; Marshall quadrangle, Marshall (station 7587?).

\section{Glyptopora aff. plumosa Prout. ${ }^{2}$}

This species is chiefly represented in one of the collections from Ramsey Ferry, where it is rather abundant. The specimens are fragmentary and preserved as molds in rather coarse sandstone. The largest are about 35 millimeters in greatest diameter. The elementary form in this species seems to be a bifoliate (?) frond, perhaps 1 millimeter in diameter. The fragments as a rule are flat over much of their extent but more or less strongly folded, chiefly

${ }^{1}$ Prout, H. A., St. Louis Acad. Sci. Trans., vol. 1, p. 573, 1860. (Coscinium sagenella.)

${ }^{2}$ Idem, p. 572. 
near the margin. The flat surfaces are furthermore modified by long ridges, more or less produced into coordinate fronds. The varied development of these two modifications gives rise to an infinite diversity of shape among the specimens, but in no specimen was a tendency to form prismatic cups observed. The more minute surface characters are of course not shown by the sandstone molds, though it is clear that the fronds were covered with fine zoœcial apertures. Evidences of maculæ are almost completely wanting, and I am inclined to think that those structures must have been sparingly developed if at all. One example does indeed show small elongated maculæ and another small rounded ones, which are, however, more suggestive of monticules, since they appear to be celluliferous. It is not at all certain that the same is not true of the elongated markings.

The incomplete prolongation of the platelike branches and the failure as a rule to unite into prismatic chambers, together with the scanty or even doubtful development of maculæ, seem to constitute important differences from most of the species thus far described. It appears to me that the affinities of this form are rather closest with $G$. plumosa, though probably good material would show it to be an undescribed species. The much less persistent development of maculæ and the much greater development of plications and of branches seem to distinguish this form satisfactorily from that cited as $G$. aff. punctipora.

In this group are also included some specimens from the town of Batesville (station 7699), where they are associated with the form called Glyptopora aff. punctipora. That type consists of flat fragments with conspicuous elongated maculæ, whereas this one comprises plicated and ridged forms without maculæ (?). At the same locality occurs also a third type, in configuration like the former but apparently without maculæ. The disposition of such specimens is uncertain.

Horizon and locality.-Batesville sandstone, Batesville quadrangle, Ramsey Ferry (station 1234A4), Batesville (station 7699),

\section{FENESTELIID AE.}

FENESTELLA Lonsdale.

\section{Fenestella tenax Ulrich.}

1888. Fenestella tenax. Ulrich, Denison Univ. Sci. Lab. Bull., vol, 4, p. 71.

Waverly group: Cuyahoga County, Ohio.

1890. Fenestella tenax. Ulrich, Illinois Geol. Survey, vol, 8, p. 546, pl. 51, figs. 2-2e.

Warsaw beds: Monroe County and Warsaw, Ill.

Chester group: Chester and Kaskaskia, Ill.; Sloans Valley, Ky. 
1895. Fenestella tenax. Keyes, Missouri Geol. Survey, vol. 5, p. 24. (Date of imprint, 1894.)

Kaskaskia limestone: Chester, Ill.

1903. Fenestella cf. tenax. Girty, U. S. Geol. Survey Prof. Paper 16, p. 339.

Hermosa formation: San Juan region, Colo.

1903. Fenestella tenax? Condra, Nebraska Geol. Survey, vol. 2, pt. 1, p. 52, pl. 8 , fig. 4.

Coal Measures: Ashland, South Bend, Falls City, Bennett, and Nehawka, Nebr.

1905. Fenestella tenax. Ulrich, U. S. Geol. Survey Prof. Paper 36, p. 34, pl. 4, fig. $2 d$.

St. Louis limestone: Four miles northwest of Princeton, Ky.

1906. Fenestella tenax. Cumings, Indiana Dept. Geology and Nat. Res. Thirtieth Ann. Rept., for 1905 , p. 1279, pl. 30, fig. 1; pl. 31, figs. 1-1b.

Salem limestone: Bedford, Ind.

Fenestellas are by no means rare in the Batesville sandstone, but their preservation, as would be expected, is highly unfavorable for successful identification. The fronds are, as a rule, broken up into fragments more or less small. The calcareous organism, except in a few small specimens from the limestone, has entirely disappeared, leaving only a mold in the sandstone which, though fine, is far too coarse to retain any of the more delicate features, and is commonly so friable that even the grosser ones are, as a rule, obliterated.

Rather contrary to what might be expected, the Fenestellas of this formation are mostly of the delicate, finely reticulate type, though possibly such species are really stronger than those having stouter branches, which are, however, far apart and less abundantly braced by dissepiments.

One of these types, from the fineness of the reticulation, can probably be referred to the abundant, long-lived, and widely distributed species $F$. tenax. About 14 rows of fenestrules occur in 5 millimeters, thus showing an agreement with typical tenax. The dissepiments are less clearly indicated than the branches and their number can not be given accurately. In their mode of growth some specimens indicate a flat front; others are more flexuous.

Horizon and locality.-Batesville sandstone, Batesville quadrangle, Ramsey Ferry (station 1234A4), Spring Creek (station 1248D), Batesville (station 7699); Marshall quadrangle, Marshall (station 7587).

\section{Fenestella aff. serratula Ulrich. ${ }^{1}$}

A second species can be distinguished among the Batesville Fenestellas, one, moreover, which seems to be more widely distributed than $F$. tenax. It is rather more coarsely reticulate, but in the sandstone molds, which usually represent it, it is sometimes not easily distinguished from $F$. tenax, which, however, seems usually to be 
represented by fragments of a large flattish frond, whereas the representatives of the other species are not uncommonly funnelshaped, and they are moreover generally more or less highly flexuous, owing to the rapid divergence of the branches. Many external molds of such specimens furthermore show a few stout, spikelike, or stolonlike projections.

Measurements are difficult to make-not only because of the preservation but because the specimens are apt to be so folded as not to afford a flat surface of the desirable length. Eleven or twelve rows of fenestrules occur in 5 millimeters transversely to the branches, and the same number of fenestrules, or slightly fewer, occur in the same distance when measurements are made longitudinally.

In some respects this species suggests $F$. serratula, which is described as constantly accompanying $F$. tenax and as differing slightly in the coarser reticulation. F. serratula, however, and most of the Carboniferous Fenestellas (all those described by Ulrich) are said to be fan-shaped or foliar in growth, and thus they clearly have a different shape. F. serratula also has less numerous fenestrules in a given longitudinal distance (17 to 19 in 1 centimeter). This is, then, probably a new species, but the material is too imperfect for description.

Horizon and locality.-Batesville sandstone, Batesville quadrangle, Spring Creek (station 1248D), beyond Spring Creek (station 1248B), Ramsey Ferry (station 1234A4), Round Mountain (station 7089), Batesville (station 7699); Marshall quadrangle, Marshall (stations 7090, 7587), Granny Mountain (station 7093b).

\section{Fenestellia sp. $a$.}

This type, which forms infundibuliform zoaria, is somewhat more coarsely reticulate than the other species of the genus discussed in this paper, and on the other hand it is somewhat finer than Polypora sp., with which it may prove to be congeneric. The character of the zoœcia is shown by a single specimen, and imperfectly in that one, but there appear to be only two rows of cells. Seven branches and also seven fenestrules occur in 5 millimeters.

Horizon and locality.-Batesville sandstone, Batesville quadrangle, Ramsey Ferry (station 1234A4); Marshall quadrangle, Marshall (station 1247A).

Fenestella sp. $b$.

This form has about the same number of branches in a centimeter as the preceding, but it has longer and slenderer -fenestrules, of which only about five occur in 5 millimeters. The single fragment found, which is less than 20 millimeters long, is rather flat, suggesting that the mode of growth is frond-shaped rather than 
infundibuliform. It does not afford means of determining whether the generic reference should be with Fenestella or Polypora.

Horizon and locality.-Batesville sandstone, Batesville quadrangle, Spring Creek (station 1248D).

\section{Fenestella sp. $c$.}

The single fragment representing this type resembles in a general way those referred to $F$. serratula? but differs in being rather more robust, about nine branches and seven fenestrules coming in a linear distance of 5 millimeters. The frond is rather flexuous and is formed of rather rapidly diverging branches. Preserved as a mold in sandstone, it appears to present the reverse side to observation, though it is the side whose curvature is not convex but concave. The branches clearly show two, or possibly more, rows of small spines, represented in the matrix by tiny holes.

The fine construction of this form would indicate that it is a Fenestella rather than a Polypora, and its proportions and other characters would seem to ally it with $F$. multispinosa.

Horizon and locality.-Batesville sandstone, Marshall quadrangle, Marshall (station 7587).

\section{POLYPORA McCOY.}

\section{Polypora sp.}

Zoarium apparently infundibuliform, though most of the specimens are fragmentary, or strongly contorted, or plicated. Fenestrules apparently elliptical, a little longer than wide. About five branches occur in 5 millimeters, though measurement is difficult because of the irregularity of the frond, the small size of the fragments, and the rapid divergence of the branches. Five, or occasionally four, fenestrules occur in 5 millimeters.

The number of rows of zoccia and the more minute characters of the surface are not shown by the specimens, which are preserved as molds in sandstone.

Horizon and locality.-Batesville sandstone, Batesville quadrangle, Ramsey Ferry (station 1234A4), Batesville (station 7699), Marshall quadrangle, Marshall (station 7587).

\section{ARCHIMEDES Lesueur.}

\section{Arcimimedes Prodtands var. Ulrich.}

1890. Archimedes proutanus var. Ulrich, Illinois Geol. Survey, vol. 8, pl. 63, figs. 11-11b.

Chester group: Chester, Ill.

This type is represented by a single imperfect fragment preserved as a mold in sandstone. It is scarcely identifiable but much suggests 
the Chester form which Ulrich figured as $A$. proutanus var. The almost complete absence of the genus Archimedes in the Batesville fauna is a noteworthy feature, this being the only specimen so far known from the region considered in this report.

Horizon and locality.-Batesville sandstone, Marshall quadrangle, Marshall (station 7587).

\section{RHOPALONARIID $A$.}

\section{RHOPALONARIA Ulrich.}

\section{Rhopalonaria? sp.}

Plate XI, figure 1.

In the sandstone beds of the Batesville sandstone the fossils are preserved as molds. In a few collections, notably that obtained at station 7699, in the outskirts of the town of Batesville, some of the cavities thus formed have retained part of the original structures replaced by limonitic or ocherous material. This is especially true of the Bryozoa.

Some of the molds of Composita are traversed by slender rounded filaments, apparently representing borings in the original shell, which has completely disappeared. These filaments are of nearly uniform size, 0.2 millimeter in diameter or less. They seem to begin at the surface of the shell and therefore to be at present connected at one end with the matrix. Some of them continue near the surface, but others penetrate well below and thus are at present entirely free for nearly their whole length. They pass above and below one another, are more or less curved, and many of them bifurcate. Possibly also some of them inosculate, though any distinct reticulate formation is absent.

The origin and nature of these structures are doubtful. They are rather too fine and of too uniform a size to be caused by boring sponges, while their small size and their character in other respects render them unlike the perforations made by gastropods and other boring mollusks. They much suggest the excavations made by the bryozoan Rhopalonaria, but if such is their nature they probably constitute a new genus.

Horizon and locality.-Batesville sandstone, Batesville quadrangle, Batesville (station 7699). 


\title{
BRACHIOPODA.
}

\section{DISCINIDAE.}

\section{IINGULIDISCINA Whitfield.}

\section{Lingulidiscina BatesviLlensis Weller.}

\author{
Plate II, figures 1, 1a.
}

1897. Orbiculoidea batesvillensis. Weller, New York Acad. Sci. Trans., vol. 16, p. 255 , pl. 18, figs. 4, 5. (Date of volume, 1898.)

Batesville sandstone: Batesville, Ark.

1909. Lingulidiscina batesvillensis. Girty, U. S. Geol. Survey Bull. 377, p. 22, pl. 1, figs. 12, 12a.

Caney shale: Atoka and. Tishomingo quadrangles, Okla.

This species is represented in the Survey collections by only one specimen, but I have also been able to examine the two typical specimens kindly loaned to me by Prof. Weller. These are dorsal valves of medium size, one of which appears to be slightly longer than wide and the other slightly wider than long. The largest diameter is about 18 millimeters. The outline is subcircular, somewhat straightened along the posterior side. The shell is inflated but not of great height, the shape being subspherical rather than subconical. The apex is small, distinctly curved backward, and situated about halfway between the center and the posterior border.

The surface was presumably marked by the sharply elevated concentric liræ characteristic of the genus. The sandstone molds that now represent the forms do not show this, however, though they do show, especially toward the margin, fine concentric striæ. The single specimen in the Survey collection is also a dorsal valve. It is slightly longer than wide, and has a length of 15 millimeters. It shows no important differences from the types.

Weller distinguished this species from $L$. newberryi by the size and by the elongated shape, differences which in fact do not exist, and I have been regarding L. batesvillensis as a synonym. However, after comparing Weller's two specimens with the types and other specimens of $L$. newberryi, I am disposed to think that, although very similar to one another, the Arkansas shell can probably be distinguished by its smaller beak, which is depressed and, as it were, bent backward, while that of $L$. newberryi is more erect and prominent.

Horizon and locality.-Batesville sandstone, Batesville quadrangle, Ramsey Ferry (station 1234A4). 


\section{CRANIID $A$.}

CRANIA Retzius.

Crania? sp.

A unique specimen, having an expanded shape and low convexity. The diameter is 5 millimeters. The shell appears to be thin and is marked by numerous fine irregular concentric wrinkles, which tend to be more or less scalloped. It is not certain that the shell is punctate.

The apical portion is broken and may have been produced into a straight or curved attenuate point, so that the shape would be more like that of Platyceras, which genus is also suggested by the sculpture. The shape, so far as it is preserved, indicates a shell unusually spreading for that group of gastropods, and the form is cited under Crania, although very provisionally.

Horizon and locality.-Batesville sandstone, Marshall quadrangle, Marshall (station 7091).

\section{STROPHOMENIDA.}

\section{SCHUCHERTELLA Girty.}

\section{Schuchertella williamsi Weller.}

Plate II, figures 2-3b.

1897. Streptorhynchus williamsi. Weller, New York Acad. Sci. Trans., vol. 16, p. 255, pl. 19, figs. 1-3. (Date of volume, 1898.)

Batesville sandstone: Batesville, Ark.

It is somewhat surprising that in the material on which he based his description of the fauna of the Batesville sandstone of Arkansas, Weller found no septate strophomenoids but only a nonseptate type, which he described under the genus Streptorhynchus, while in the Survey collections the septate type is relatively abundant and only one ventral valve without a septum has come to hand. I may here recall that since the generic characters are resident chiefly in the ventral valve, since no two valves of one specimen have been found in conjunction, and since the dorsal valves seen by me do not present any appreciable differences of internal or external character on which a specific division could be based, a complete separation of these types is impossible.

Through the courtesy of Prof. Weller in loaning me the type specimen of $S$. williamsi, I have been able to examine two ventral valves, the type specimen and another collected by Mr. Ulrich at the same locality. 
The type specimen is imperfect in the apical region but hardly so imperfect as I was led to infer from Weller's figure. The imprint of a very short septum might in this way have been obscured, but the Orthotetes from the same locality have a long septum. It is possible that a septum was originally present and that it was broken off before fossilization, but the more recently acquired specimen lessens the probability of such an occurrence, in itself not very probable.

Although the occurrence of a nonseptate strophomenoid at this horizon and in this area is most unexpected, in spite of Streptorhynchus ulrichi described by Hall and Clarke, the evidence at hand seems to justify no other conclusion as to the real internal character.

As to the generic position of this species, which was originally described as Streptorhynchus williamsi, Weller writes me that he has on reconsideration felt disposed to change the reference to Schuchertella. In this course I am ready to concur. It seems more probable, from such facts as are available in the category of range and distribution of species, that Schuchertella williamsi is a survival of Schuchertella rather than an early occurrence of Streptorhynchus, for all the typical forms of Streptorhynchus known from American rocks (S. ulrichi excepted, and this also should probably be referred to Schuchertella) are of a much more recent geologic period and are more western in their distribution.

Intrinsically the characters of $S$. williamsi are ambiguous. The area is too high and the growth too irregular for typical Schuchertella, and on the other hand there is no evidence whatever of cementation, a character, it is true, not always found in typical Streptorhynchus. The development of the dental callosities would not be out of place in either genus. The shape is transverse, as in Schuchertella, and the hinge line short, as in Streptorhynchus, but to neither of these characters can much importance be attached. The characters of the dorsal valve might be taken as more indicative of Streptorhynchus were it not that we have no way of ascertaining that these valves do not in fact belong to the Orthotetes which occurs in the same beds.

As for the specific characters of $S$. witliamsi, Weller has mentioned those shown by the type specimen. The ventral valve is large and transverse, and it would be rather highly elevated were it not that the axis inclines backward, so that the area is oblique to the edge of the shell by an angle of about $45^{\circ}$. The area is high and flat and the pseudodeltidium much higher than wide. The dental callosities are short and considerably thickened. The growth is rather irregular, and the outline contracts toward the hinge. The sculpture is obscure, but the sandstone impression, in which form the specimen occurs, shows indications of a large flabelliform scar. 
The second ventral valve, that which belongs in the Survey collection, answers to the above description in most respects. It is smaller than the type, more strongly transverse, very much more irregular in growth, and the area is less inclined backward and consequently has a greater proportional elevation. This specimen is not broken like the other. It shows no trace of a septum but has two thickened dental ridges. In addition, this specimen shows the sculpture, which consists of fine rounded, rather crowded, nearly equal radial liræ, of which 13 to 14 occur in 5 millimeters.

I shall not give the character of the dorsal valve, because it is not certain that the dorsals so far examined do not belong to the associated species of Orthotetes. Granting that the dorsals are in the same proportion as the ventrals, we must believe that some if not most of them belong to Orthotetes subglobosus var. batesvillensis, and if any of them belong with Schuchertella williamsi there is at present no way of distinguishing the two species on the character of this valve.

Horizon and locality.-Batesville sandstone, Batesville quadrangle, Ramsey Ferry (station 1234A4), Batesville (station 7699?).

\section{ORTHOTETES Fischer-de-Waldheim.}

\section{OrTHotetes subgLobosus Girty?}

1910. Orthotetes subglobosus. Girty, New York Acad. Sci. Annals, vol. 20, No. 3 , pt. 2, p. 214 .

Fayetteville shale: Fayetteville quadrangle, Ark.

A few specimens from a limestone at the top of the Batesville sandstone near Batesville are distinguished from the other shells in the colleetion by having coarse and strongly alternating liræ, in which respect they agree with typical $O$. subglobosus. They are too fragmentary, however, to show whether there is an equal agreement in other respects.

Horizon and locality.-Batesville sandstone, Batesville quadrangle, Round Mountain (station 7089).

Orthotetes subglobosus var. BAtesvillensis n. var.

Plate I, figures 1-5.

Shell attaining a large size, few specimens, however, exceeding 55 millimeters in width. Width considerably in excess of the length. Outline rounding inward at the hinge, which is much shorter than the width below. Ventral valve moderately high with an area only slightly inclined backward. Growth more or less contorted. The median septum is thin, high, and long, reaching one-third to onehalf the length of the valve. The dental plates are rather short and 
thick; they unite above with the septum, forming with the pseudodeltidium a small triangular chamber.

No dorsal valves have been found in position, but it seems reasonable to assume that most of them belong to this species rather than to the much rarer Schuchertella williamsi. They are, as a rule, rather strongly convex. The cardinal process is nearly perpendicular to the plane of the shell edge, of moderate size, and more or less distinctly bilobate. In the older shells the posterior portion is commonly more or less thickened and a low, rounded ridge or septum is developed. The cardinal process connects anteriorly with two short socket plates, which diverge at an angle of about $130^{\circ}$.

The surface is marked by fine rounded, crowded, nearly equal, radiating liræ, of which 13 to 16 occur in 5 millimeters. These are crossed by the usual fine crenulations.

This variety would appear from the Survey collections to be rather abundant in the Batesville sandstone, and it is worthy of note that Prof. Weller did not obtain it, although he did obtain the much rarer Schuchertella williamsi. However, there is no method known to me of distinguishing dorsal valves of these two species, so that perhaps the present one is in fact represented among his material by dorsal valves. Indeed, there is no assurance that his type specimens, in so far as they are dorsal shells, may not belong to Orthotetes. My specimens are fairly constant in the characters enumerated above. Perhaps the greatest variation is found in the height and irregularity in growth of the ventral valves, some of which are low and fairly regular, while others are more elevated and more contorted.

I have been in some doubt as to whether this form should not be referred directly to Orthotetes subglobosus. From the evidence in hand, however, there seems to be a real and constant difference, the dorsal valve being less gibbous than the types of that species and the liræ more crowded and less conspicuously alternating. I am not satisfied as to the value of these differences, yet feel loath to disregard them when they appear to be fairly constant.

The generic position also is not definitely fixed. It lies between Derbya and Orthotetes, and I have never been entirely satisfied that both these groups should be regarded as valid genera. It will be recalled that Waagen, who proposed the name Derbya, recognized them only as different manifestations of the same generic type. Where characteristically developed, these two types of structure appear distinct enough, but there are many species which are not typical. The present variety is one of these. Here the dental plates are short and the posterior edge of the septum passes obliquely forward from the apex. Thus, the three plates approach each other closely enough to form the characteristic structure for only a short distance. It would evidently be difficult to ascertain whether the 
plates met near the apex to form a $Y$-shaped figure with the septum, or passed on either side of the septum without uniting with it, and in the present case the difficulty is enhanced by the fact that they are more or less completely fused in an apical callosity. Among the specimens before me some seem to give evidence of an incipient camerate structure where they emerge from the callosity, but others seem at least to show indications of the other type, through the septum projecting, for a very short distance it is true, between the edges of the dental lamellæ without uniting with them.

Horizon and locality.-Batesville sandstone, Batesville quadrangle, Ramsey Ferry (station 1234A4), Batesville (station 7699), Spring Creek (station 1248D), beyond Spring Creek (station 1248B); Marshall quadrangle, Marshall (stations 7039a, 7587, 7090), Granny Mountain (stations 7093a, 7093b).

\section{Orthotetes SUbGLobosus var. PRotensus Girty?}

Plate I, figure 6.

1910. Orthotetes subglobosa var. protensa. Girty, New York Acad. Sci. Annals, vol. 20 , No. 3, pt. 2, p. 214.

Fayetteville shale: Fayetteville quadrangle, Ark.

Two ventral valves, one from Marshall and one from Batesville, are distinguished by having very high and very sloping cardinal areas. They differ from one another in that the Marshall specimen is an elongated shell with regular growth and the Batesville specimen a transverse shell with contorted growth. The liration in the Marshall specimen is also somewhat alternating, while in the Batesville specimen it is very nearly equal. The Marshall specimen shows the presence of a median septum and of dental lamellæ, but the anterior extremity is so broken that the mutual relation of the plates can not be determined. In the other specimen the three plates are likewise present and so directed apparently that they would not meet except at the extreme apex, though the apical callosity has so connected them as to inclose a small conical or prismatic chamber. One of the dental plates also divides (or else its impression is confused with a fragment of another shell) in a way which it is impossible quite to make out or understand. Though these two specimens agree with one another and with the variety protensus in the character which distinguishes the latter from typical subglobosus, it is not certain that they really belong with that variety or with one another. They differ sufficiently from the variety batesvillensis to make a tentative separation desirable.

In addition $I$ include here a few dorsal and ventral valves from a limestone in the upper part of the Batesville sandstone near Batesville. The two ventral valves indicate a high area with characteristic 
camerate structures and a median groove down the narrow pseudodeltidium. The dorsals are distinguished from the few fragments referred to 0 . subgtobosus, with which they are associated, by their rather fine subequal liræ, a surface character which in some measure distinguishes the type specimen of the variety protensus from typical subgtobosus. They might almost as well, however, be referred to the variety batesvitlensis.

Horizon and locality.-Batesville sandstone, Batesville quadrangle, Ramsey Ferry (station 1234A4), Round Mountain (station 7089 ) ; Marshall quadrangle, Marshall (station 7090).

\section{PRODUC'TIDE.}

\section{PRODUCTELLA Hall.}

\section{Productella hirsutiformis Walcott.}

\section{Plate II, figure 4.}

1884. Productella hirsutiformis. Walcott, U. S. Geol. Survey Mon. 8, p. 133, pl. 2, fig. 10 .

Upper Devonian: Eureka and White Pine districts, Nev.

1909. Productella hirsutiformis. Girty, U. S. Geol. Survey Bull. 377, p. 24, pl. 2, figs. 4-6.

Caney shale: Ardmore, Atoka, and Tishomingo quadrangles, Okla.

1911. Productella hirsutiformis. Girty, U. S. Geol. Survey Bull. 439, p. 50, pl. 3, figs. 1-4.

Moorefield shale: Batesville quadrangle, Spring Creek; Moorefield, Ark.

This interesting species is represented by a single specimen, which, though imperfectly preserved, can be identified with some certainty. It is probably an external mold of a dorsal valve and shows the low convexity, broad, semicircular shape, distinct cardinal area, and surface nearly smooth or marked only by fine concentric striæ and growth lines, characteristic of the species.

Although the identification is safe there may be some question as to the stratigraphic position. The specimen was not found in place, and instead of being whitish or brownish like the typical Batesville sandstone the matrix is of a grayish tint and apparently has a slight admixture of clay, though it is at the same time a quartz sandstone. The character of the rock is that which the Batesville might have in a transitional or contact zone between the sandstone and the black shale of the Moorefield. It is lithologically quite different from the earthy limestone phase of the Moorefield (the so-called "Spring Creek limestone") which, though black on fresh exposure, weathers to a soft brown sandy rock. This specimen bears the same locality number as others which are lithologically more typical of the Batesville.

Horiaon and locality.-Batesville sandstone, Batesville quadrangle, Round Mountain (station 7089); Spring Creek (station 1248B). 


\title{
PRODUCTUS Sowerby.
}

\section{Productus arkansanus Girty.}

\author{
Plate II, figures 5-7.
}

1910. Productus arkansanus. Girty, New York Acad. Sci. Annals, vol. 20, No. 3, pt. 2, p. 216.

Fayetteville shale: Fayetteville quadrangle, Ark.

Ventral valve of medium size, subtriangular, rather strongly and regularly expanding from beak to front, the triangular shape that results not being obscured by any considerable development of the auricles, which are small. The hinge line is shorter than the width in front. The convexity is moderately strong and there is a broad undefined median sinus.

The dorsal valve is for the most part nearly flat, so that a considerable cavity is left for the soft parts. About the margin, however, it is strongly and rather abruptly bent. The outline is subquadrate, contracting posteriorly. A low, ill-defined mesial fold is a constant feature.

The sculpture consists in principle of elongated spine bases which have a quincunxial arrangement. In some specimens these spine bases are conspicuously independent; in others they are connected into more or less continuous, though nodulose costæ. Much variation is manifested in the coarseness and fineness of this sculpture, which seems to be of similar character in both valves, so that they are equally provided with numerous small, regularly arranged spines. The surface is also crossed by a few irregular wrinkles most conspicuous on the sides and ears.

In a general way this species resembles Diaphragmus fasciculatus, although really distinct both specifically and generically. Imperfect and obscured as many specimens from the sandstone are, it is sometimes impossible to refer individuals satisfactorily to one species or the other.

In point of distribution $P$. arkansanus is not rare in the sandstone beds at Marshall. A single doubtful example has been obtained from the calcareous upper part of the formation at the same locality, and two specimens have also been found at Batesville, though here also the identification is not beyond question.

Horizon and locality.-Batesville sandstone, Batesville quadrangle, Ramsey Ferry (station 1234A4), Batesville (station 7699); Marshall quadrangle, Marshall (stations 7091?, 7092a, and 7587), Granny Mountain (station 7093b). 


\title{
Productus inflatus var. coloradoensis Girty (?)
}

\author{
Plate III, figures 7-8a.
}

?1890. Productus boliviensis (non d’Orbigny). Nikitin, Com. gêol. [Russia]

Mém., vol. 5, No. 5, pp. 57, 158, pl. 1, figs. 4a, 4b, 4c.

Gschelstufe: Near Moscow, Russia.

?1902. Productus inflatus (non McChesney). Tschernyschew, idem, vol, 16, No. 2 , pp. 261,612 , pl. 28 , figs. $1-6$.

Gschelstufe: Ural and Timan Mountains, Russia.

1903. Productus inflatus (non McChesney). Girty, U. S. Geol. Survey Prof.

Paper 16, p. 359, pl. 3, figs. 1-1b, 2, 2a, 3.

Hermosa formation: San Juan region and Ouray, Colo.

Weber limestone: Crested Butte and Leadville districts, Colo.

Pennsylvanian: Glenwood Springs, Colo.

1904. Productus inflatus? (non McChesney). Girty, U. S. Geol. Survey Prof.

Paper 21, p. 52, pl. 11, figs. 5, 6.

Pennsylvanian (Naco limestone) : Bisbee quadrangle, Ariz.

1910. Productus inflatus var. coloradoensis. Girty, New York Acad. Sci.

Annals, vol. 20, No. 3, pt. 2, p. 215.

Basal Fayetteville shale: Fayetteville quadrangle, Ark.

1911. Productus inflatus var. coloradoensis? Girty, U. S. Geol. Survey Bull.

439, p. 42, pl. 4, figs. 3, 3a.

Moorefield shale: Batesville quadrangle, Spring Creek, Ark.

In the sandstone and limestone beds of the Batesville sandstone there appears to occur, though somewhat rarely, a representative of the semireticulatus type of Productus, but, although the presence of this group is rather probable, there are some specimens which, because of characters actually intermediate, and others which, because of a general obscuring of characters, especially of those on which we rely for identifying this species, it is impossible to distinguish satisfactorily from $P$. arkansanus and Diaphragmus fasciculatus.

It is probably safe to affirm that the semireticulatus group of Producti was derived from the Productella type by the elongation of the spine bases until they developed into strong, even, radial costæ. The transverse wrinkles, of course, are found to a greater or less degree in almost all members of the genus and it is their fineness, regularity, and persistence across the dome of the shell which, with the regular and rigid strix, constitute the chief distinction of the semireticulate Producti.

It is thus that actual intergradation apparently is found with $P$. arkansanus. The sculpture of that species, which theoretically consists of quincunxially arranged spines having elongated bases, tends to pass into a regularly costate type by the prolongation of the spine bases so that they form with others in the same row consecutive costæ. The Batesville shells referred to the semireticulatus group differ from $P$. arkansanus in having continuous and regular costæ, a less abundant development of spines, stronger and more regular $49778^{\circ}-$ Bull. $593-15-4$ 
wrinkles, and a more extended hinge line with larger ears. At the same time the shape is less conspicuously triangular. In addition to a tendency to intergrade, the imperfect preservation of many specimens, especially those from the sandstone horizons, renders it impossible to place them satisfactorily in one group or the other.

Of course it should in theory be easy to distinguish these supposed Producti semireticulati from Diaphragmus fasciculatus, for in no case has the characteristic diaphragm been observed in the dorsal valve, but with dissociated ventrals and poorly preserved dorsals this fundamental criterion can not of course be applied. D. fasciculatus is, as a rule, more finely costate, more elongated; it has less ample auricles and less regular transverse wrinkles, but in the use of these characters also the imperfect condition of preservation introduces a great element of doubt into some identifications.

Even the shells which are most characteristic of this species, as here constituted (and they come mainly from the earthy limestone near Marshall), do not have the semireticulatus expression in a thoroughly typical degree. This is shown by a lack of strength and regularity in the wrinkles and in an unusual development of spines, especially on the dorsal valve, where in the most typical semireticulate Producti they are rare if not altogether lacking.

If there is some uncertainty about these forms really belonging to the semireticulate group of Productus, still more uncertainty surrounds their identification with the variety coloradoensis, an identification which has, moreover, been hampered by rather scanty and rather imperfect material.

Horizon and locality.-Batesville sandstone, Batesville quadrangle, Ramsey Ferry (station 1234A4), Spring Creek (station 1248D); Marshall quadrangle, Marshall (stations 7091, 7092, and 7092a).

\section{Productus pileiformis McChesney.}

?1853. Productus cora. Shumard, Marcy's Exploration of the Red River, Ia., p. 202, pl. 1, fig. 1. (As a Senate Ex. Doc.)

Carboniferous: Washington and Crawford counties, Ark.

?1854. Productus cora. Shumard, Marcy's Exploration of the Red River, La., p. 176. (As a House Ex. Doc.)

Carboniferous: Washington and Crawford counties, Ark.

1855. Productus cora. Norwood and Pratten, Acad. Nat. Sci. Philadelphia. Jour., 2 d ser., vol. 3 , p. 6.

Mountain limestone: Chester, Rosiclare, and Warsaw, Ill., near Richmond, Mo.; Carrsville, Ky.

1860. Productus pileiformis. McChesney, Description of new species of fossils from the Paleozoic rocks of the Western States, p. 40 . (Date of imprint, 1859.)

Kaskaskia division: Chester, Ill.

1863. Productus coræformis. Swallow, Acad. Sci. St. Louis Trans., vol. 2, p. 94 Archimedes limestone: Cooper County, Mo. 
1891. Productus pileiformis. Whitfield, New York Acad. Sci. Annals, vol. 5, p. 582 , pl. 13, figs. 13,14 .

Maxville limestone: Ohio.

1895. Productus pileiformis. Whitfield, Ohio Geol. Survey Rept., vol. 7, p. 470, pl. 9, figs. 13, 14. (Date of imprint, 1893.)

Maxville limestone: Ohio.

1896. Productus cora (pars). Smith, Am. Philos. Soc. Proc., vol. 35, p. 238.

Archimedes limestone: Independence County, Ark.

Marshall shale: Independence and Stone counties, Ark.

Fayetteville shale: Independence County, near Moorefield, Ark.

1896. Productus cora (pars). Smith, Leland Stanford Junior Univ. Pub., Contr.

Biology Hopkins Seaside Lab. No. 9, p. 28.

Archimedes limestone: Independence County, Ark.

Marshall shale: Independence and Stone counties, Ark.

Fayetteville shale: Independence County, Ark.

1909. Productus pileiformis. Girty, U. S. Geol. Survey Bull. 377, p. 26, pl. 2, fig. 7.

Caney shale: McAlester quadrangle, Okla.

- 1911. Productus pileiformis. Girty, U. S. Geol. Survey Bull. 439, p. 44, pl. 4, figs. 1-2a.

Moorefield shale: Batesville quadrangle, Marshall quadrangle, Ark.

Productus pileiformis is exceedingly abundant at Marshall and it is exceedingly rare at Batesville. The Survey collections from Batesville contain only three or four specimens, and Weller does not cite the species at all.

This is a rather large form, and the ventral valve is highly convex, somewhat narrower than the Pennsylvanian $P$. cora, and without any trace of a sinus, which in that species is usually suggested by at least a flattening of the mesial portion of the valve. The ears are large, depressed, and explanate.

The dorsal valve is shaped much like the ventral, but it is less convex posteriorly and has a much less prominent and incurved beak.

The sculpture consists of the usual fine and more or less irregular and tortuous liræ. Large, strong wrinkles are developed on the ears, becoming finer and fainter as they cross the vault of the shell, even if they do not die out altogether. They are rather more conspicuous and persistent on the dorsal valve than on the ventral. Spines are, as a rule, rather abundant and large. They are distributed somewhat evenly over the surface without, however, showing any regular or persistent arrangement. Over the umbonal region they appear to be absent. They would there naturally be small and are perhaps broken or worn away. A few specimens show several thickly set rows along the hinge line, but in most of them this feature has not been observed, although it may be present. For the size of the liræ the spines are relatively large, interrupting them or causing them to be diverted from a direct course. They do not have elongated bases nor seem, as a rule, to form conspicuous nodes. On the interior of the ventral 
valve they are commonly marked by an internal rib which extends forward some distance from the base and produces on molds of the interior a series of narrow grooves or striæ. This manifestation is, however, confined to the median portion, no spines being developed on the posterior portion, as already noted, while on the anterior portion the spines are marked on the inside of the shell, if at all, by a thickening of the test about their bases. In the dorsal valve spines are apparently absent altogether, the corresponding feature consisting of little dimples which appear as nodes on the external mold, the form in which dorsal valves usually occur.

At station 7089 is found a small or dwarfed variety of this species.

Horizon and locality.-Batesville sandstone, Batesville quadrangle, Ramsey Ferry (station 1234A4), Batesville (station 7699), Round Mountain (station 7089); Marshall quadrangle, Marshall (stations 1247A, 7090, and 7587), Granny Mountain (station 7093a).

\section{Productus adairensis Drake.}

Plate III, figure 6.

1898. Productus (Marginifera) adairensis. Drake, Am. Philos. Soc. Proc., vol. 36, p. 402, pl. 9, figs. 1-3. (Reprinted in Leland Stanford Junior University Pub., Contr. Biology Hopkins Seaside Lab. No. 14, same date, page, etc.)

Boone limestone (Burlington-Keokuk): Three miles southeast of Westville; seven miles east of Adair.

Boston group (St. Louis-Chester) : Five miles east of Adair.

This species is extremely rare in the Batesville sandstone, only one specimen having come to hand, but it is in good condition and the identification is accurate. The specimen, which represents an external and an internal mold of a dorsal valve, shows a small shell, moderately concave, with a distinct mesial fold and somewhat flattened and extended ears. The external mold does not retain any impression of costæ, appearing to be entirely smooth.

Productus adairensis is a typical fossil of the basal Fayetteville fauna, which occurs immediately above what is called the Batesville sandstone in the Fayetteville quadrangle, and the specimen in this collection came from the Batesville sandstone at Marshall.

Horizon and locality.-Batesville sandstone, Marshall quadrangle, Marshall (station 7587).

\section{DIAPHRAGMUS Girty.}

Dr. J. W. Beede has recently commented upon the structural type which I am calling Diaphragmus with the opinion that it is not adequately distinguished from Marginifera. Dr. Beede can hardly have a true understanding of the types of structure which I seek to desig- 
nate by the terms Diaphragmus and Marginifera, or else he places very different values on these structures in taxonomy. Dr. Beede's reasons for the opinion so at variance with my own deserve to be quoted in full. ${ }^{1}$ He says :

Since this discussion was written a copy of Girty's paper, in which he describes the new subgenus Diaphragmus, has come to notice. The character upon which this subgenus is based is exhibited in specimens from the Chester group and in a fragmentary specimen figured later from the Moorefield shales. The specimens from older rocks at Cape le Trou and Oyster basin have this feature well developed. Indeed, there is some suspicion of its presence in what may be Strophalosias from the latter locality. This character seems to have originated as early as the lowest Kinderhook or later Devonic in such shells as Productus dissimilis Hall, and reached its fullest development in Marginifera muricata, M. splendens, and $M$. voabashensis. The presence of the "plate" or "diaphragm" is to be regarded as the inception of shell deposition in the peripheral region of the brachial valve together with its geniculation and later became more and more pronounced, resulting in sharp murication of the Pennsylvanic species. Since somewhat similar characters occur in other shells of the Strophomenacea the structure is of doubtful systematic significance at best, and the splitting up of the subgenus Marginifera on the basis of the extent of the deposit seems hardly warranted.

This quotation from Dr. Beede consists $(a)$ of a statement of fact as to eertain structures in Productus, Diaphragmus, and Marginifera, coupled with an explanation of the biologic relationship of the structures, and $(b)$ of a conclusion as to the generic affinities of these types as determined by these facts and this theory, coupled with a generalization as to the relationship between structural development and generic discrimination.

I understand Dr. Beede to say in the first category that the structure of Diaphragmus and Marginifera is the same, that it occurs sporadically in some of the Producti (Productus dissimilis Hall), and reached its fullest development in Marginifera muricata, $M$. splendens, and $M$. wabashensis.

In my opinion the structure which may be called the marginal callosity is found only in Marginifera and that which may be called the diaphragm only in Diaphragmus. In this place, as elsewhere unless otherwise stated, when I speak of Marginifera I refer to the type of structure exemplified by our American species, especially by Marginifera splendens, the genotype. The Indian species described by Waagen may be different generically and more closely allied to Diaphragmus. To this point reference will be made later. The dorsal valve in typical Marginifera then is bordered by a heavy callosity formed by layers of shell piled one on top of another like the leaves of a book. A growth analogous to this occurs here and there in many and widely different types of brachiopods, chiefly in

${ }^{1}$ Beede, J. W., New York State Mus. Bull. No. 149, p. 165, 1911. 
very old or in pathologic specimens, where the mantle, having apparently reached its maximum size, proceeded to make testaceous deposits, chiefly along the margins of the valve, in such a way as to increase their convexity but not increase their spread. There is only a partial analogy in such development, however, for the callosity in Marginifera is a persistent feature and is found only in one valve, whereas in such types as Composita and Spirifer it is found only occasionally and is equally developed in both valves.

In Marginifera, then, to return to our metaphor, the leaves of the book face outward and the back faces inward, toward the cavity of the shell, projecting somewhat so as to form a low ridge. One cover of the book (the outer) is of course continuous with the major and much thinner portion of the dorsal valve, while the inner cover lies flat against the inner surface of the ventral valve at its edge. This internal ridge is practically marginal throughout its course, but just as it dies down toward the hinge the ends are conspicuously curved inward. Simultaneously with the dying down of this ridge the shell deposits on the outside, which look like piled up lamellæ and of which the ridge is an internal expression, die out likewise. On its outer surface, especially at the sides, the ridge is finely and rather strongly crenulated, the little teeth doubtless fitting into little sockets in the other valve. Now, the ridge is low and the actual differences involved are so small as to be inconsiderable, but it is evident as a matter of geometry that if the ridge were inclined slightly inward, away from the other valve, it would not form a partition, whereas if it leaned slightly outward, or toward the other valve, it would help divide the inside of the shell from the outside, not divide the inside of the shell into chambers. However, the position of the ridge is practically, if not absolutely, marginal, so that no essential difference would be made by these considerations, and if the crenulated exterior of the ridge indicates a contact surface with the other valve, as is strongly suggested, it is clear that the ridge must be absolutely terminal so far as the interior of the dorsal valve is concerned, except possibly at its ends.

Strongly in contrast with the structure just described, the diaphragm in Diaphragmus is situated at the geniculation of the dorsal valve, or about midway between the back and the front of the shell. It is a long thin partition flung completely across the inner cavity of the shell, which it divides into two chambers. It is purely an internal structure, like a median septum, and not an expression on the interior of some correlated external feature.

If asked to account for the presence of the marginal ridge of Marginifera my surmise would be that it might be connected with the very unequal convexity of the two valves. In Marginifera splendens, for instance, the dorsal valve is only very gently concave, 
passing almost directly from the hinge to the front, a distance which is traversed by the ventral valve in a much higher arc. The superficies of the dorsal valve in some specimens could hardly have been much more than half that of the ventral valve and if we may assume a general tendency toward equality in the dorsal and ventral portions of the mantle, both as to size and secretion, the callosity of the one valve may be in a measure a compensation for the greater size of the other. However that may be, it seems to me that the effect of the structure, whatever its origin, must have been not at all in the nature of a partition but partly as a buttress and partly as an aid in retaining the valves securely in place, a function for which there would be real need in view of the obsolete condition of the hinge teeth. In Diaphragmus, on the other hand, the significant structure clearly served as a partition, and from its position and fragile structure it could have been of little use in strengthening the shell and none in locking it.

For these reasons it seems to me that the structures in Marginifera and Diaphragmus, far from differing only in degree, are intrinsically quite distinct, that they served different functions and probably had different origins, and a very casual observation should show that even if they were homologous structures they did not reach their fullest development in typical Marginifera but are far more highly developed in typical Diaphragmus - at least if such an expression can be used when Diaphragmus has no external callosity whatever and when the submarginal ridge of Marginifera does not function as a partition. It is significant in this connection to note that Diaphragmus preceded Marginifera in time of development.

The structure which I have assigned to Marginifera is confirmed by numerous observations and by very perfect material, such as specimens weathered from shale, in which it is certain that little or no breakage has been suffered. Waagen, however, asserts that the characteristic structure of Marginifera forms a partition by which "the visceral part of the shell is perfectly chambered off from the remainder of the shell," and that no evidence of this structure is to be seen on the exterior, which is exactly that of Productus. This is only partly true and then only true in a sense of typical Marginifera, for though the marginal ridge is seen only on the inside of the shell, the lamellæ of which it is composed are equally obvious on the outside in well-preserved specimens. Furthermore, the ridge does not chamber off the visceral region from anything but the outside of the shell. Though he took our American species as the type of the genus, Waagen's own observations were made on specimens from India collected, I would judge, from a limestone, and I am inclined to believe that the correctness of his observations was somewhat impaired as to detail by imperfect material. If he does, in- 
deed, accurately describe the character of the Indian forms, I should be inclined to doubt the advisability of including them under Marginifera.

With Dr. Beede's statement of fact I am unable to agree, for the reasons which have just been set forth, and the explanation of the evolution of the structure which he offers appears to me equally unsatisfactory. The heart of the matter seems to be contained in the sentence: "The presence of the 'plate' or 'diaphragm' is to be regarded as the inception of shell deposition in the peripheral region of the brachial valve together with its geniculation and later became more and more pronounced, resulting in sharp murication of the Pennsylvanic species," and I confess that I do not understand what the author means. Surely shell deposition in the dorsal valve of this or any other type can not be thought to have had its inception in the peripheral region. Then this inception of shell deposition seems to be locally connected in the mind of the author with the peripheral region and at the same time with the geniculation. But it hardly needs to be pointed out that the peripheral region is the outer edge of the shell and the geniculation, roughly speaking, about halfway back. Again, the author coins a new word for the occasion. "Murication" is not to be found in the dictionaries, but fortunately its meaning can scarcely be doubted. It must be derived from the Latin muricatus, from which we have the English muricated, and its meaning, of course, must be the presence or development of sharp points or spines. I am puzzled to trace any connection between the internal plate of Diaphragmus or the marginal callosity of Marginifera and the development of spines from which, exempli gratia, Marginifera muricata gets its name.

In the second category I understand Dr. Beede to say that structures similar to the ones on which Diaphragmus and Marginifera are based (which I do not agree to be the same) are found in other shells of the Strophomenacea and that for this reason they are of doubtful systematic importance at best. One would expect that almost any structure of any genus of the Strophomenacea would be found in some other member of the same superfamily, yet that of itself hardly vitiates the systematic importance of such a structure. I suppose that exactly the same reasoning would apply to other superfamilies and that the punctate shell structure and median septum of Spiriferina, which are found in other shells of the Spiriferacea, vitiate the genus Spiriferina.

I judge that what Dr. Beede really had in mind was this: Since the types in question (Productella, Productus, Diaphragmus, and Marginifera) are essentially alike in other particulars, a structural character in one of them loses its systematic value if it is found 
sporadically in another. I am not sure that I would be willing to grant this as a general proposition.

Hall and Clarke, I may add, state that Waagen expresses the opinion that the American species (of Productus as implied in the context) belong for the greater part to Marginifera and they add: ${ }^{1}$

It is extremely doubtful if the evidence will sustain this assumption, though there are certain species of the Coal Measures, Productus splendens Norwood and Pratten, $P$. longispinus Sowerby, $P$. lasallensis Worthen, which show the characters of Marginifera in some stage of development.

In the species. Productus dissimitis Hall, from the middle Devonian of Rockford, Iowa, and the upper Devonian of New York, similar internal characters are quite strongly developed, especially in the pedicle valve, and in both valves the margins of the ridges are more or less distinctly crenulated. While the species has the cardinal area, teeth, and sockets in an exceedingly obscure condition, the cardinal process is like that of Productella, strongly bifurcated to its base, and its external surface presents characters rarely met with either in Productus or Productella but not uncommon in Strophalosia-a spiniferous pedicle valve and a brachial valve without spines but covered with concentric lamellose ridges.

Hall and Clarke apparently refer in this place to a sentence on page 715 of Waagen's monograph, ${ }^{2}$ which, it seems to me, they failed to understand. It reads as follows:

Thus all the coal-measure species of America, which probably are for the greater part Marginifera, have been united by Mr. Davidson with Productus longispinus Sowerby, and yet I must consider Marginifera splendens, Productus wabashensis, and Productus capacii each as a different and well-distinguishable species.

Waagen is here discussing not the species which should be referred to Marginifera but the specific relations of different Marginiferæ to one another and especially to his Indian species. Thus, he says that there is a group of American species from the "Coal Measures" which are probably for the greater part Marginifera, and which Davidson united with Productus longispinus, but which he considered individually distinguishable and distinct also from his Indian forms.

To recapitulate my own views, I do not regard the structures of Diaphragmus and Marginifera as the same, and so far as they have points of similitude it is not Marginifera but Diaphragmus in which they are more highly developed. If reliance may be placed on Hall and Clarke's figures, I should be loath to admit that the structure of Productella dissimilis is really the same as that of Marginifera, or, if it is the same, that it is developed in such a degree (there is nothing to correspond to the callosity of Marginifera except some structures near the hinge, which might be likened to the ends of the

1 Hall and Clarke, New York Geol. Survey, Paleontology, vol. 8, pt. 1, p. 332, 1892. This statement is probably the basis for Dr. Beede's reference to the occurrence of similar characters in other shells of the Strophomenacea.

${ }^{2}$ Waagen, W., India Geol. Survey Mem., Palæontologia Indica, ser. 13, vol. 1, p. 715, 1887. 
submarginal ridges) that there can be any serious question of its belonging to Marginifera. Productella dissimilis clearly does not exemplify the Diaphragmus structure. If, however, the structures of Marginifera or Diaphragmus do indeed occur sporadically or partly developed in the early Mississippian or late Devonian, a fact as to which I am somewhat uncertain, this would hardly be a valid argument against giving the characters full value when their development is strong and constant, especially in a group which furnishes so few differentiating characters as the productoids.

Indeed, the more consideration I give to Diaphragmus the more satisfied am I that it deserves recognition both for its own sake, for its stratigraphic significance, and for convenience in designating a peculiar if small group of productoids from the less discriminate host of more closely related species. In my judgment it rests on more valid characters than Productella or Marginifera. I have never seen a specimen from the Mississippian that by any stretch of sound judgment could be referred to Marginifera, and I have never seen any specimens of Diaphragmus in the Pennsylvanian. Diaphragmus seems, in fact, to be peculiar to and characteristic of the upper Mississippian horizons, and to have had a very wide distribution in that zone. Both from this fact (if indeed Dr. Beede's Productus tenuicostatiformis is a Diaphragmus, as his statements indicate) and from the general make-up of the fauna, so far as that can be grasped from printed observations only, I am inclined to believe that the fauna of the Magdalen Islands is not lower Mississippian, as Dr. Beede seems to conclude, but upper Mississippian.

\section{Diaphragmus fasciculatus McChesney.}

\section{Plate III, figures 1-4.}

1860. Productus fasciculatus. McChesney, Description of new species of fossils from the Paleozoic rocks of the Western States, p. 38.

Kaskaskia limestone: Fountain Bluff, Kaskaskia, and Chester, IIl.; Leavenworth, Ind.

1911. Diaphragmus elegans. Girty, U. S. Geol. Survey Bull. 439, p. 51, pl. 4, figs. 4 , 5.

Moorefield shale: Batesville quadrangle, Spring Creek, Ark.

This species is abundant both at Batesville and at Marshall. Indeed, it is the only productoid cited by Weller in his description of the Batesville sandstone and its fauna. At Marshall it occurs chiefly in the limestones intercalated in the upper part of the formation. In the sandstone it is rare.

Although abundant, specimens are usually in a poor state of preservation, being for the most part crushed and often preserved as molds in the rather coarse sandstone. In addition to being compressed, some specimens give evidence of having been injured and 
repaired during the life of the animal. As a result of these causes many specimens can not be satisfactorily distinguished from related and associated species.

In size the fossils referred to $D$. fasciculatus are medium or rather small. When immature the shape is broader than long, but mature specimens are elongated. The outline is more or less quadrate, contracted at the hinge.

The ventral valve is highly arched, with the posterior part incurved and the anterior extended; the expansion is more or less rapid. A shallow undefined mesial sinus is a rather constant feature and one which is apt to be exaggerated on internal molds, owing to the thickening of the shell down the umbonal region.

The dorsal valve is flattened over the posterior region, and in some specimens is sharply geniculate where this area joins the lateral slopes.

The surface is marked by fine, strong, rigid, occasionally irregular liræ. The visceral area is often crossed by fine irregular concentric wrinkles, obscure in some specimens and rarely conspicuous in any. There are also strong regular striæ of growth. Spines are rather numerous but small. As a rule they do not make nodes or swellings on the costre and consequently are apt to be overlooked except on external molds. On some internal molds they are indicated by narrow, discontinuous striæ which indent the tops of the costæ for some distance. The spines are distributed somewhat sparsely over most of the surface but are thick and bushy at the sides of the ventral valve. They are probably absent altogether from the dorsal valve. Some specimens develop longitudinal folds, chiefly observable toward the front of old specimens. Sometimes this is the result of irregular loose plication of the shell, sometimes of a tendency of the ribs to divide into two or three smaller ones, forming fascicles.

Many specimens of the dorsal valve show the characteristic internal partition of Diaphragmus marked by fine radial striæ instead of by distinct ribs.

This form is apparently the same that occurs in the Moorefield shale (so-called "Spring Creek limestone" phase) and, though noting certain differences from typical $D$. elegans, I thought it unwise to attempt to distinguish them. After having examined a much larger series of specimens, I now regard it as a distinct though closely related and not always easily separated species. It is a larger shell, more spreading, and has a fairly constant and distinct sinus. There can hardly be a doubt that this is the form which McChesney described as Productus fasciculatus, although as indicated by my specimens the fasciculation is only an occasional character and is not a practicable one for distinguishing this species from D. elegans. 
McChesney's description I quote in full for the convenience of the reader: ${ }^{1}$

Shell rather below medium size, elongated; length of the hinge line threefourths the greatest width of the shell, and auriculate. Ventral valve strongly arcuate, flattened on the top, or marked by a broad shallow sinus; sides nearly perpendicular, which, together with the flattened top, gives it a somewhat angular appearance; auricles recurved, pointed, with the sides of the shell just in front of them somewhat contracted; beak small, pointed, slightly projecting beyond the hinge line. Dorsal valve profoundly concave, slightly flattened over the visceral area, and prolonged in front and at the sides with the ventral valve, and recurved at the cardinal extremities or auricles.

Surface of the ventral valve marked by medium-sized rounded radiating ribs, which are increased by bifurcation, and toward the front of the shell several of them unite in fascicles, which are not developed except in adult individuals and are not seen when the prolonged portion of the valve is broken away. The surface is also marked by very fine concentric striæ and a few faint wrinkles of growth on the upper part of the shell, and traces of spine bases very sparingly scattered over the surface, except on the sides immediately over the ears, where there is a cluster of 8 or 10. The cavity of the dorsal valve is also marked by radiating ribs, finer than those of the ventral valve, and frequently bifurcating, giving them a somewhat contorted appearance. The concentric wrinkles of this valve are more distinct than those of the other valve near the cardinal lines, sometimes of equal strength with the radiating ribs, and bending over upon the reflected portion of the valve which forms the auricles.

Specimens of this species are usually found with the prolonged portion of the valves broken away, entirely changing the appearance of the shell from that presented by perfect individuals.

The animal appears to throw a partition across from the dorsal to the ventral valve, which appears, when the prolongment is broken away, to be the continuation of the flattened portion of the valve over the visceral portion, and nearly conforming to its concavity, though destitute of its distinct ribs, the visceral portion being distinctly limited by an imbricated ridge.

This species has usually been referred to $P$. flexistria of McCoy, from which it differs in being much less inflated over the ears and toward the beak, and in the strix uniting into fascicles toward the front. It is more nearly related to $P$. elegans ${ }^{2}$ than to the last-mentioned species but is a much broader shell, is frequently marked by a distinct mesial sinus, more extended on the hinge line, much less marked by tubercles, and having the fasciculate striæ on the front of the ventral valve.

Geological position and localities.-In the Kaskaskia division of the Carboniferous limestone series, at Fountain Bluff, Kaskaskia, and Chester, Ill., and Leavenworth, Ind.

Horizon and locality.-Batesville sandstone, Batesville quadrangle, Ramsey Ferry (station 1234A4), Spring Creek (station 1248D?), beyond Spring Creek (station 1248B), Batesville (station 7699?); Marshall quadrangle, Marshall (stations 7090, 7091, 7092, 7587), Granny Mountain (stations 7093, 7093a).

${ }_{1}$ McChesney, J. H., Descriptions of new species of fossils from the Paleozoic rocks of the Western States, p. 38, 1861.

2 Norwood, J. G., and Pratten, Henry, Acad. Nat. Sci. Philadelphia Jour., 2d ser., vol. 3, August, 1854 . 


\section{Diaphragmus elegans Norwood and Pratten.}

Plate III, figures 5, 5a.

1854. Productus elegans. Norwood and Pratten, Acad. Nat. Sci. Philadelphia Jour., 2d ser., vol. 3, p. 13, pl. 1, figs. 7a-c. (Not P. elegans McCoy.)

Mountain limestone: Chester and Kaskaskia, Ill., near Hat Island, Mo. 1860. Productus Cestriensis. Worthen, Acad. Sci. St. Louis Trans., vol. 1, p. 570.

Chester limestone: Chester, IIl.

1877. Productus elegans. Hall and Whitfield, U. S. Geol. Expl. 40th Par. Rept., vol. 4 , p. 268 , pl. 5 , figs. 3,4 .

Lower Carboniferous limestone: North of Snowstorm Hill, Dry Canyon, Oquirrh Mountains, Utah.

1891. Productus elegans. Whitfield, New York Acad. Sci. Annals, vol. 5, p. 581, pl. 13, figs. $15,16$.

Maxville limestone: Ohio.

1895. Productus cestriensis. Keyes, Missouri Geol. Survey, vol. 5, p. 44. (Date of imprint, 1894.)

Kaskaskia limestone, St. Mary, Mo.

1895. Productus elegans. Whitfield, Ohio Geol. Survey Rept., vol. 7, p. 469, pl. 9, figs. 15, 16.

Maxville limestone: Ohio.

1897. Productus cestriensis. Weller, New York Acad. Sci. Trans., vol. 16, p. 256, pl. 19, figs. 7-9. (Date of volume, 1898.)

Batesville sandstone: Batesville, Ark.

1897. Productus fasciculatus (pars). Schuchert, U. S. Geol. Survey Bull. 87, p. 323.

A few specimens are distinguished by their small size, narrow shape, rounded dorsum not depressed into a sinus, and relatively coarse liration. In these particulars they agree rather with $D$. elegans than with the associated $D$. fasciculatus. The small ventral valve shown by my figure is characteristic of this group of specimens and represents a mutation which it may perhaps be desirable to distinguish from typical $D$. elegans in some subordinate category.

Horizon and locality.-Batesville sandstone, Batesville quadrangle, Round Mountain (station 7089).

\section{RHYNCHONELLID $A$.}

\section{CAMAROTGCHIA Hall and Clarke.}

Camarotechia purduei Girty.

Plate IV, figure 5 .

1910. Camarotœchia purduei. Girty, New York Acad. Sci. Annals, vol. 20, No. 3, pt. 2, p. 219.

Basal Fayetteville shale: Fayetteville quadrangle, Ark.

1911. Camarotoechia purduei. Girty, U. S. Geol. Survey Bull. 439, p. 60, pl. 5, figs. 5, 5a.

Moore shale: Batesville quadrangle, Ark.

In the sandstone beds of the Batesville sandstone, at Batesville, a rather large rhynchonelloid of the Camarotoechia type is fairly com- 
mon. The length and width are very nearly equal. But few specimens attain a diameter of 15 millimeters. The plications are strong, angular, and rather coarse and they extend backward nearly or quite to the beaks. There are normally four plications, rarely three or five, in the fold, and three in the sinus, with five or sometimes four lateral ones on either side of the dorsal valve.

Internally the ventral valve bears the usual strong dental plates and the dorsal a median septum, which supports at the apex a flat hinge plate or small spondylium, the exact character and relations of which are not clearly indicated by the material examined.

There can scarcely be a doubt that this is the same species which I described from the underlying Moorefield shale as Camarotochia purduei, or that it is the same species which Weller tentatively identified as Rhynchonella mutata, his specimens being obtained from the same locality and horizon as my own. The one which he figures is considerably smaller than the largest in my collection. I do not, however, believe that this is true Pugnax mutata of Hall.

In its generic relations this appears to be a representative of Camarotochia rather than of any of the new groups proposed by Weller.

Horizon and locality.-Batesville sandstone, Batesville quadrangle, Spring Creek (station 1248D), Batesville (station 7699); Marshall quadrangle, Marshall (station 7587).

\section{Camarotechia purduei var. inflata n. var.}

Plate IV, figures 1-4a.

At Round Mountain, west of Batesville, a small Camarotœrhia occurs in the upper calcareous portion of the Batesville sandstone in great abundance. But few specimens attain a length of 9 millimeters. The usual variations in proportion and shape are found among these specimens, some being about as broad as they are long, others more slender, and the outline may be oval or subcircular, or more or less pentagonal or quadrate. As a rule the convexity is high. The dorsal valve normally has four plications on the fold, but specimens having three are rather numerous. The lateral plications generally number three large and one small, or more rarely four large and one small, though on some specimens even six lateral plications can bs counted. The last two or three, however, are obscure and are represented rather by denticles along the margin than by plication on the surface. The plications tend to be low and rounded, although in some specimens they are stronger and more angular. The lateral plications are likely to be larger than the mesial ones. The fold is commonly not elevated above the arch of the shell except close to the front, and its limits are usually best determined in the anterior 
view, which shows a conspicuous elevation along the line of union of the valves.

On the inside the ventral valve bears the usual pair of dental plates, and a median septum is present in the dorsal valve, but the other structures have not been determined.

In the number and arrangement of the plications this form is closely related to $C$. purduei. It is considerably smaller, considerably more convex, and has wider and more rounded costæ. It appears to be a distinct variety, although a few examples having a more compressed shape and sharper ribs might pass for small individuals of the other species.

Horizon and locality.-Batesville sandstone, Batesville quadrangle, Round Mountain (station 7089).

\section{TEREBRATULID $\boldsymbol{A}$.}

\section{DIELASMIA King.}

\section{Dielasma formosum var. whitfieldi Girty?}

Plate V, figures 1-1b.

1910. Dielasma formosum var. whitfieldi. Girty, New York Acad. Sci. Annals, vol. 20, No. 3, pt. 2, p. 220.

Basal Fayetteville shale: Fayetteville quadrangle, Ark.

Clearly there is at least one other species of terebratuloid in the Batesville sandstone in addition to Girtyella turgida var. elongata, from which it is distinguished by being larger, more elongate, more regularly oval, and by lacking the characteristic plications toward the front of the shell, even when of larger size than mature individuals of that species.

When specimens having these characters have been selected, they prove to have all come from the Batesville region, and some of them show the Dielasma structure and consequently belong to a genus distinct from the other. Some of the specimens occur in sandstone and are in a very poor state of preservation. Others that come from the calcareous horizons near the top of the formation are more satisfactory. They show three septal plates in the dorsal valve and one of them seems to possess the characteristic platform, thus showing the typical Dielasma structure. The largest of these specimens agrees very closely in shape with $D$. formosum var. whitfieldi, although in size it is considerably smaller. Some of the sandstone specimens are much larger than those from the limestone and also larger than typical $D$. formosum var. whitfieldi.

It is not certain that the sandstone specimens belong even to the genus Dielasma, but probably they do and are conspecific with those from the limestone. 
Small specimens of this form are readily separated from $D$. turgida var. elongata by the determination of internal structures. On external characters the separation is not so easy. The greater proportional length, more regularly oval outline, and absence of plications are the most reliable criteria, but it must be borne in mind that some specimens of the Girtyella have the plications less distinct than others and that in all immature shells this character is partially developed. In some specimens, therefore, especially young specimens, it is necessary to resort to generic characters for separation.

Horizon and locality.-Batesville sandstone, Batesville quadrangle. Ramsey Ferry (station 1234A4), Spring Creek (station 1248D), Round Mountain (station 7089).

\section{GIRTYELLA Weller.}

\section{Girtyella turgida var. elongata Weller.}

Plate V., figures 2-3a.

1897. Dielasma turgida var. elongata. Weller, New York Acad. Sci. Trans., vol. 16, p. 260, pl. 19, fig. 6. (Date of volume, 1898.)

Batesville sandstone: Batesville, Ark.

1910. Harttina brevilobata var. marginatis. Girty, New York Acad. Sci. Annals, vol. 20, No. 3, pt. 2, p. 219.

Basal Fayetteville shale: Fayetteville quadrangle, Ark.

1911. Harttina brevilobata var. marginalis. Girty, U. S. Geol. Survey Bull. 439, p. 66 , pl. 2, fig. 13 .

Moorefield shale: Batesville quadrangle, Ark.

Small terebratuloids are moderately abundant in the sandstone beds of the Batesville sandstone at Batesville, and they are very abundant in the calcareous beds which occur in the upper part of the formation at Marshall. There is no reason to believe that the species is not the same in both occurrences, although of course the limestone furnishes much the better specimens. These show the shape to be elongate and subpentagonal, the ventral beak rather large, projecting, and incurved, and the convexity moderate. The ventral valve has a sinus which is moderately deep and narrow and which extends about halfway back from the front of the valve.

The dorsal valve is without a fold entirely corresponding to the sinus, though it is often slightly elevated along the middle, the elevation being exaggerated near the front by two little sulci. This configuration causes the front to appear truncated, and this with a tendency in the lateral outlines to be somewhat straightened above and below produces a more or less pentagonal outline. Slight variations from this arrangement result in a more regularly oval outline or more rarely one which is subtriangular.

The average specimen has the length perhaps one and one-fourth times the width, but there are varieties in which the length is only 
slightly greater than the width, and others which are still narrower than the average. Specimens also differ in the strength of the plications and in the degree of convexity. As a rule the convex individuals appear to be the most strongly plicated. Young specimens of course have the plications weaker than old ones, and they have at the same time a relatively broader shape and lower convexity.

On the inside the ventral valve has the two strong dental plates common to most Paleozoic terebratuloids, while the dorsal valve bears only a median septum, the auxiliary plates and platform of Dielasma being wanting. There is, however, a shelf-like plate across the posterior extremity of this valve supported by the end of the septum. The lines of junction of this platform with the sides of the shell produce on internal molds what appear to be small plates strongly diverging and slightly curved, situated close to the margin at the posterior extremity. Elongate adductor scars, fairly deep but illdefined, can often be observed on either side of the dorsal septum. Some specimens at least have a linear thickening down the middle of the ventral valve forming a sort of low obseure septum.

These well-preserved limestone specimens are clearly the species which I described as Harttina brevilobata var. marginalis, while the sandstone specimens are probably the form which Weller described as Dielasma turgidum var. elongatum. But few of the specimens from either the sandstone at Batesville or the limestone at Marshall are as narrow as the variety elongatum, and those which have that shape owe it in part to compression. Though the loop has not been ascertained to be short, it seems highly probable that these specimens belong to the group for which Weller has recently proposed the generic name Girtyella, to which his Dielasma turgidum var. elongatum probably belongs. It would thus appear that my variety marginalis is probably a synonym of his previously described elongatum. It would also be better to consider this a variety of turgida, which is likewise a member of the genus Girtyella.

Horizon and locality.-Batesville sandstone, Batesville quadrangle, Ramsey Ferry (station 1234A4), beyond Spring Creek (station 1248B?), Round Mountain (station 7089), Batesville (station 7699); Marshall quadrangle, Marshall (station 7091, 7092, 7092a), Granny Mountain (station 7093).

\title{
SPIRIFERID $A$.
}

\section{SPIRIFER Sowerby.}

\section{SPIRIFER INCREBESCENS Hall.}

\author{
Plate IV, figures 7,8 .
}

1858. Spirifer increbescens. Hall, Iowa Geol. Survey Ann. Rept., vol.. 1, pt. 2, p. 706 , pl. 27 , figs. $6 \mathrm{a}-\mathrm{i}$.

Kaskaskia limestone: Kaskaskia and Chester, Ill.

$49778^{\circ}-$ Bull. $593-15-5$ 
1858. Spirifer keokuk var. Hall, Iowa Geol. Survey Ann. Rept., vol. 1, pt. 2, p. 676 , pl. 24 , figs. $4 \mathrm{a}$ ?, $4 \mathrm{~b}, 4 \mathrm{c}, 4 \mathrm{~d}$ ?.

St. Louis limestone: Mouth of Lizard Creek, Webster County, Iowa.

1883. Spirifera increbescens. Hall, New York State Geologist Rept. for 1882, pl. (30) 55, figs. $27-30$, pl. (31) 56, figs. 1-3.

Chester limestone: Illinois.

1888. Spirifer increbescens. Herrick, Denison Univ. Sci. Lab. Bull,, vol. 4, pl. 11, figs. 14, 23.

Chester limestone: Ohio; also from limestone fragments in Pennsylvanian conglomerate, Licking County, Ohio.

1893. Spirifer increbescens. Hall and Clarke, New York Geol. Survey, Paleontology, vol. 8, pt. 2, pp. 27, 39. (Advance distribution in fascicles.)

1894. Spirifer increbescens. Hall and Clarke, New York State Geologist Thirteenth Ann. Rept., for 1893, vol. 2, pl. 27, figs. 8-11.

Chester limestone: Chester, Ill.

1894. Spirifer increbescens. Hall and Clarke, Introduction to the study of the Brachiopoda, pt. 2, pl. 27, figs. 8-11.

Chester limestone: Chester, IIl.

1895. Spirifera increbescens. Keyes, Missouri Geol. Survey, vol. 5, p. 82. (Date of imprint, 1894.)

Kaskaskia limestone: St. Mary, Mo.

1895. Spirifer increbescens. Hall and Clarke, New York Geol. Survey, Paleontology, vol. 8 , pt. 2 , pp. 27,39 , pl. 30 , figs. $27-30$, pl. 31 , figs. $1-3$.

Chester limestone: Chester, IIl.

1897. Spirifer Keokul. Weller, New York Acad. Sci. Trans., vol. 16, p. 257, pl. 19, figs. 10-12. (Date of volume, 1898.)

Batesville sandstone: Batesville, Ark.

1911. Spirifer increbescens. Girty, U. S. Geol. Survey Bull. 439, p. 68.

Moorefield shale: Batesville quadrangle, Spring Creek, Ark.

The specimens included here show a rather small shell, which attains a width of perhaps 25 millimeters but usually measures 18 millimeters or less. It is transverse and usually widest just in front of the hinge, the cardinal angles being somewhat rounded. They may also be quadrate or pointed but are never extended. The convexity, height of the area, and other dimensions are moderate and normal for this group. The fold contains 4 and the sinus 3 costæ, and there are 8 or 9 , sometimes 10 , lateral costæ, which are often larger than the mesial ones. The mesial rib in the sinus and the mesial furrow on the fold are, as a rule, conspicuously larger than their fellows.

The sculpture is not well shown. In a few limestone specimens and even in a few sandstone molds the surface shows fine superimposed liræ traversing the plications, and there were doubtless fine concentric liræ, which produced with them more or less of a cancellation.

This is clearly the same form which occurs in the basal Fayetteville shale and which in that fauna I identified as $S$. increbescens. It is also the same form that Weller identified from the same formation and locality as Spirifer keokuk, with an oblique reference to 
increbescens. S. keokuk and S. increbescens are very closely allied, but it seems to me that the present form is more like increbescens.

Horizon and locality.-Batesville sandstone, Batesville quadrangle, Ramsey Ferry (station 1234A4), Spring Creek (station 1248D), beyond Spring Creek (station 1248B), Round Mountain (station 7089), Batesville (station 7699); Marshall quadrangle, Marshall (station 7091, 7092), Granny Mountain (station 7093 ?).

\section{RETICULARIA McCoy.}

\section{Reticularia setigera Hall?}

Plate IV, figure 6.

1858. Spirifer setigerus. Hall Iowa Geol. Survey Ann. Rept., vol. 1, pt. 2, p. 705, pl. 27 , figs. $4 \mathrm{a}, 4 \mathrm{~b}$.

Kaskaskia limestone: Kaskaskia and Chester, Ill.

1877. Spirifera setigera. Hall and Whitfield, U. S. Geol. Expl. 40th Par. Rept., vol. 4, p. 270, pl. 5, figs. 17, 18.

Lower Carboniferous limestone: North of Snowstorm Hill, Dry Canyon, Oquirrh Mountains, Utah.

1883. Spirifera setigera. Hall, New York State Geologist Rept. for 1882, pl. (36) 61, figs. 26, 27.

Chester limestone: Chester, Ill.

1883. Reticularia setigera. Waagen, India Geol. Survey Mem, Palæontologia Indica, ser. 13 , vol. 1, p. 542.

1893. Spirifer setigerus. Hall and Clarke, New York Geol. Survey, Paleontology, vol. 8, pt. 2, pp. 21, 37. (Advance distribution in fascicles.)

1895. Spirifer setigerus. Hall and Clarke, idem, pp. 31, 37, pl. 36, figs. 26, 27. (Date of imprint, 1894.)

Chester limestone: Chester, Ill.

1895. Spirifer setigera. Keyes, Missouri Geol. Survey, vol, 5, p. 83. (Date of imprint, 1894.)

Kaskaskia limestone: St. Mary, Mo.

1906. Reticularia setigerus. Beede, Indiana Dept. Geol, and Nat. Res. Thirtieth Ann. Rept., for 1905, p. 1318, pl. 21, figs. 1, 1a.

Salem limestone: Lanesville and Bedford, Ind.

1911. Reticularia setigera. Girty, U. S. Geol. Survey Bull. 439, p. 69, pl. 8, figs. 6, 6a.

Moorefield shale: Batesville quadrangle, Spring Creek, Ark.

The Survey collection contains a single specimen of what is undoubtedly a species of Reticularia, related to pseudolineata and setigera. It is an internal mold of a dorsal valve and it has been distorted by oblique compression, which has probably heightened the elevation and distinctness of the mesial fold. The length of the specimen is 24 millimeters and the original width was probably not far from 34 millimeters, the shape being approximately that of a transverse, broadly rounded ellipse. There was present a median septum. The character of the sculpture can only be inferred from the evident generic relationship. 
In default of all knowledge of the detailed character of the sculpture and even of the exact proportions of the shape, there must enter a large element of doubt into the identification of this specimen. It is provisionally placed with $R$. setigera, but if my restoration is correct the width is rather excessive for that species and the specimen may be a pseudolineata.

Weller does not record any representative of this genus in his work on the fauna of the Batesville sandstone.

Horizon and locality.-Batesville sandstone, Batesville quadrangle Ramsey Ferry (station 1234A4).

\section{SPIRIFERINA D'Orbigny.}

\section{SPIRIFERINA SPINOSA Hall.}

Plate IV, figure 9.

1855. Spirifer spinosus. Norwood and Pratten, Acad. Nat. Sci. Philadelphia Jour., $2 \mathrm{~d}$ ser., vol. 3 , p. 71 , pl. 9 , figs. 1a-d.

Top of Mountain limestone: Chester, IIl.; Pope County, III.; and in Missouri opposite Hat Island.

1856. Spiriferina spinosa. Hall, Albany Inst. Trans., vol. 4, p. 8.

Warsaw limestone: Bloomington, Ind.; Alton, Ill.

1858. Spirifer spinosus. Hall, Iowa Geol. Survey Ann. Rept., vol. 1, pt. 2, p. 706, pl. 27 , figs. 5a-c.

Kaskaskia limestone: Kaskaskia and Chester, Ill.; Crittenden County, Ky.

1883. Spiriferina spinosa. Hall, New York State Geologist Rept. for 1882, pl. (35) 60, figs. 26-29.

Chester limestone: Chester, Ill.

1884. Spiriferina cristata (pars). Walcott, U. S. Geol. Survey Mon. 8, p. 218, pl. 18, fig. 12 (not fig. 13).

Chester limestone: Chester, Ill.

1891. Spiriferina spinosa. Herrick, Geol. Soc. America Bull., vol. 2, p. 46, pl. 1, fig. 19.

Upper Waverly group: Scioto County, Ohio.

1893. Spiriferina spinosa. Hall and Clarke. New York Geol. Survey, Paleontology, vol. 8, pt. 2, pp. 52-54. (Advance distribution in fascicles.)

1894. Spiriferina spinosa. Hall and Clarke, New York State Geologist Thirteenth Ann. Rept., for 1893, pl. 31, figs. 4-7.

Chester limestone: Chester, $\mathrm{Ill}$.

1894. Spiriferina spinosa. Hall and Clarke, Introduction to the study of the Brachiopoda, pt. 2, pl. 31, figs. 4-7.

Chester limestone: Chester, IIl.

1895. Spiriferina spinosa. Keyes, Missouri Geol. Survey, vol. 5, p. 85.

Kaskaskia limestone: St. Mary, Missouri. (Date of imprint, 1894.)

1895. Spiriferina spinosa. Hall and Clarke, New York Geol. Survey, Paleontology, vol. 8, pt. 2, pp. 52-54, pl. 35, figs. 26-29.

Chester limestone: Chester, Ill.

1896. Spiriferina cristata (pars). Smith, Am. Philos. Soc. Proc., vol. 35, p. 242. Lower Carboniferous (Boone chert, Upper Burlington or Lower Keokuk) : St. Joe, Searcy County, Ark. 
1897. Spiriferina cristata (pars). Smith, Leland Stanford Junior Univ. Pub. Contr. Biology Hopkins Seaside Lab. No. 9, p. 32.

Lower Carboniferous (Boone chert, Upper Burlington or Lower Keokuk) : St. Joe, Searcy County, Ark.

There are two well-marked types of Spiriferina in our upper Mississippian rocks. The spinosa type is characterized by having relatively few strong plications of nearly equal size, the fold and sinus not being much larger or more prominent than the others nor marked by a faint median plication, and the surface being covered by small spines or tubercles. The transversa type has more numerous plications, a fold and sinus conspicuously larger and more prominent than the lateral ribs and marked with a small mesial plication, and the surface is covered with closely and regularly arranged concentric lamellæ.

The genus Spiriferina is rare among the fossils of the Batesville sandstone, and the specimens thus far examined are in a poor condition for identification. Nevertheless, it has been determined that both types of shell are found among them and possibly a third type as well. The most satisfactory specimens of the spinosa type consist of an external mold of a dorsal valve and an internal mold of a ventral valve from station $1234 \mathrm{~A} 4$, which show the external and internal characters of the species as satisfactorily as the rather coarse sandy matrix would permit. The dorsal valve has five and the ventral valve four large plications on each side of the fold and sinus.

In the synonymy of this species I have included only part of the citations of Walcott and of Smith, eliminating from Walcott's citation his identification of Eureka district specimens and from Smith's citation his identification of Pennsylvanian fossils. It is not certain that S. spinosa does not occur in the Eureka district, and it is certain that $S$. spinosa, or a species very closely related to it, does occur in the Pennsylvanian. On the other hand, both authors regard $S$. spinosa as being the same species as $S$. kentuckyensis and the same as $S$. cristata. Now there is no doubt whatever that $S$. spinosa and $S$. kentuckyensis are quite distinct from each other, and it seems reasonably certain that they are also distinct from S. cristata. Furthermore, the authors do not furnish satisfactory evidence for determining whether part or all of their S. cristata may not be S. kentuckyensis, though it seems probable that part at least belongs with $S$. spinosa. On the other hand, it seems unlikely to me that $S$. spinosa really occurs in the Boone, as cited by Smith, but I have strong doubt whether the strata at St. Joe, which he calls "Boone cherts," are as old as "upper Burlington or lower Keokuk." 
I have also removed entirely Herrick's ${ }^{1}$ citation of Waverly fossils from Scioto County, Ohio. A species of Spiriferina occurs in abundance at Sciotoville, at a lower horizon than that at which I judge Herrick's "S. spinosa" to have been found. I believe that this type ranges a good deal higher than the horizon of the famous beds at Sciotoville, and at least no difference is shown between Herrick's figure and these specimens. The specimens clearly do not belong to S. spinosa, however, but to the species which Herrick himself described as S. depressa. To that species his citation has provisionally been removed.

Horizon and locality.-Batesville sandstone, Batesville quadrangle, Ramsey Ferry (station 1234A4).

\section{SPIRIFERINA TRANSVERSA Hall.}

Plate IV, figure 10.

1860. Spirifer transversa. McChesney, Descriptions of new species of fossils from the Paleozoic rocks of the Western States, p. 42. (Date of imprint, 1859.)

Kaskaskia division: Buzzards Roost, Ala.

1865. Spirifer transversa. McChesney, Illustrations of new species of fossils from the Paleozoic rocks of the Western States, pl. 6, figs. 3a-c.

1868. Spirifer transversa. McChesney, Chicago Acad. Sci. Trans., vol. 1, p. 34, pl. 6, figs. 3a-c.

Chester division: Buzzards Roost, Ala.

1874. Spiriferina transversa. Derby, Cornell Univ. (Science) Bull., vol. 1, No.

2, p. 21 , pl. 2 , pls. $4-6,13$; pl. 3, figs. $12-14$, 17 ; pl. 5, figs. 4 .

Coal Measures: Bomjardim and Itaituba, Brazil.

1883. Spirifera transversa. Hall, New York State Geologist Rept. for 1882, pl. (35) 60, figs. 19-25.

Keokuk limestone: Southern Indiana.

Chester limestone: Buzzards Roost, Ala.

Carboniferous: Brazil, South America.

1893. Spiriferina transversa. Hall and Clarke, New York Geol. Survey, Paleontology, vol. 8, pt. 2, pp. 46, 64. (Advance distribution in fascicles.)

1894. Spiriferina transversa. Hall and Clarke, New York State Geologist Thirteenth Ann. Rept., for 1893, pl. 31, figs. 1, 3.

Chester limestone: Buzzard's Roost, Ala.

Carboniferous limestone: Itaituba, Brazil.

1894. Spiriferina transversa. Hall and Clarke, Introduction to the study of the Brachiopoda, pt. 2, pl. 31, figs. 1, 3.

Chester limestone: Buzzards Roost, Ala.

Carboniferous limestone: Itaituba, Brazil.

1895. Spiriferina transversa. Hall and Clarke, New York Geol. Survey, Paleontology, vol. 8 , pt. 2 , pp. 46,64 , pl. 35, figs. $19,20,23-25$.

Chester limestone: Buzzards Roost, Ala.

Carboniferous limestone: Itaituba, Brazil.

This form is represented by several external and internal molds. The fold and sinus are much larger and more prominent than the 
lateral costæ and bear a small median plication. The lateral costæ number about eight. The external molds show the surface to be marked by regular fine concentric lamellæ.

Horizon and locality.-Batesville sandstone, Batesville quadrangle, Ramsey Ferry (station 1234A).

\section{ATHYRID E.}

\section{CLIOTHYRIDINA Buckman.}

\section{· Cliothyridina sublameliosa Hall.}

Plate IV, figures 11-13.

1858. Athyris sublamellosa. Hall, Iowa Geol. Survey Ann. Rept., vol. 1, pt. 2, p. 702, pl. 27 , figs. 1a-c.

Kaskaskia limestone: Chester, Ill.; Crittenden County, Ky.

1863. Spirigera Americana. Swallow, Acad. Sci. St. Louis Trans., vol. 2, p. 89.

(Date of imprint, 1868.)

Ste. Genevieve limestone: Chester, Ill.; St. Mary, Mo.

?1877. Athyris planosulcata? Hall and Whitfield, U. S. Geol. Expl. 40th Par. Rept., vol. 4, p. 257, pl. 4, figs. 10-11.

Lower Carboniferous limestone (Waverly?) : Cottonwood Divide, 800 feet east of Reed \& Benson's mine, Wasatch Range, Utah.

1893. Cliothyris sublamellosa. Hall and Clarke, New York Geol. Survey, Paleontology, vol. 8, pt. 2, fasc. 1, p. 91 .

1895. Athyris sublamellosa. Keyes, Missouri Geol. Survey, vol. 5, p. 92. (Date of imprint, 1894.)

Kaskaskia limestone: St. Mary, Mo.

1894. Cliothyris Roysii. Hall and Clarke, Introduction to the study of the Brachiopoda, pt. 2, pl. 35, figs. 9, 10.

Keokuk group: Keokuk, Iowa.

Chester limestone: Jackson County, Ky.

1895. Cliothyris Roysii. Hall and Clarke, New York Geol. Survey, Paleontology, vol. 8 , pt. 2 , pl. 46 , figs. 23,24 .

Keokuk group: Keokuk, Iowa.

Chester limestone: Jackson County, Ky.

1895. Cliothyris sublamellosa. Hall and Clarke, idem, p. 91.

In dealing with internal molds it is necessary to exercise care in discriminating the athyroids and terebratuloids, especially ventral valves. It is often even more difficult to distinguish between the different types of athyroids, in the present case between Cliothyridina and Composita. Fortunately a few exfoliated examples from the calcareous upper beds of the Batesville sandstone betray the typical surface structure of Cliothyridina, obscure concentric striæ indicating the superficial lamellæ and obscure radiating striæ the fimbriæ of spines. Even without these specimens, however, those from the sandstone would, by their configuration, have indicated rather satisfactorily a species of Cliothyridina closely related to $C$. sublamellosa. This is shown in their rather small size, high convexity, more trans- 
verse shape, and slightly developed fold and sinus. The largest specimen referred to this species has a width of 17 millimeters and a length of 14 millimeters. It is a dorsal valve.

Weller did not record any species of Cliothyridina in the fauna of the Batesville sandstone.

The Cliothyridinæ are difficult to classify. For many reasons, of which this is one, the synonymy of some of our American species is very complicated. C. sublamellosa belongs in this class, its synonymy being involved with $C$. roissyi, $C$. planisulcata, and other species. With the data now at hand, however, it is possible to make at least a start in assembling the different citations in their true relationship. In the first place citations of Cliothyridina roissyi (often misspelled royssi) by American authors appear to have been based on interpretations by Davidson and De Koninck. If the interpretation of this species be confined rather strictly to the type of shell figured by l'Eveillé it is doubtful whether $C$. roissyi or any species closely related to it is as yet known from American rocks. Cliothyridina? prouti is the most semblable.

In his valuable bibliography and synonymy of American Carboniferous invertebrates Prof. Weller includes $C$. sublamellosa and several other American species in the synonymy of $C$. roissyi. I propose to take these citations up serially and indicate their probable generic and specific positions.

Typical C. roissyi, as already noted, is probably not American.

Terebratula roissyi of Marcou is almost certainly a Composita, probably $C$. subtitita.

Athyris sublamellosa Hall I propose to retain in Cliothyridina under the specific name given by the author.

Terebratula planisulcata of Marcou again is almost certainly a Composita, more or less closely related to $C$. subtilita.

Athyris parvirostris Meek and Worthen (1860), a name which was abandoned in 1866 when the form was placed under Athyris planisulcata?, is of doubtful generic affinities. I have suspected that it would prove to be a Camarophorella. At any rate its generic position is uncertain, and until more definite information is had it would probably be best to retain it as Athyris? parvirostris.

Spirigera pectinifera of Swallow is almost certainly the same as Cliothyridina incrassata, of which I shall have more to say. The only character in which Swallow regarded his species as differing from Athyris incrassata of Hall was the pectinated lamellæ, and Hall's species is now known to possess that character and to belong to the genus Cliothyridina.

Spirigera americana Swallow, ${ }^{1}$ there can hardly be much doubt, was founded on specimens of the present species, Cliothyridina sublamellosa.

Athyris sublamellosa of Derby can probably be placed under the closely related species $C$. orbicularis, where Geinitz's Athyris planisulcata also belongs, together with White's Spirigera planisulcata (1877).

${ }^{1}$ Hall and Clarke place $C$. americana in the synonymy of $C$. hirsuta, with which Swallow himself compares it, but from the size, locality, and faunal association it is more probably the same as 0 . sublamellosa. Keyes, also, is of this opinion. 
The relationship of Athyris planisulcata? of Hall and Whitfield is very doubtful. Their two figures may represent different species and one of these may be a Composita, to which group the smaller may also belong. In default of better knowledge as to their true relationship, this citation is temporarily retained.

Athyris roissyi of Meek (1877) is a form of doubtful generic and specific affinities, and in $1899 \mathrm{I}$ introduced for it the new name mira, and for the present it may stand as Athyris? mira.

Athyris sublamellosa of Keyes is probably correctly referred, and the citation may stand under Hall's species.

Cliothyris roissyi was cited by Hall and Clarke in 1894 and 1895 from both the "Keokuk group" and the "Chester limestone." On the score of probabilities I would be disposed to place the Keokuk species with $C$. incrassata as a young individual and the Chester species with $C$. sublamellosa, but provisionally they may be retained in this synonymy. The description is so worded that one might almost think the two figures were made from the same specimen.

An interpretation similar to that suggested above is adopted with regard to Weller's own citation of $C$. roissyi from the Fern Glen limestone member of the Kinderhook formation. $C$. incrassata also appears in that fauna, and it seems to me that the shells called $C$. roissyi might be young individuals of the same species. At all events he offers evidence to show that they are not $C$. sublamellosa, and it is clear that they can not be true roissyi.

Having proceeded so far with the assembling of these citations, especially the citations of $C$. roissyi, most of which apparently belong with $C$. incrassata, it is permissible to draw a few conclusions regarding the synonymy of the latter species.

I have seen no reason to change the reference of the different shells which have been identified as $C$. incrassata, but there are a number of other citations, some of which have already been mentioned, which probably go with them. I am satisfied that McChesney's Athyris obmaxima belongs in this synonymy. That species was originally described from the Keokuk limestone at Nauvoo, Warsaw, and Keokuk, whereas $C$. incrassata was described from the Burlington limestone at Burlington and other places, but Spirigera pectinifera from the geode beds at Keokuk is almost certainly a synonym of $C$. incrassata, and Hall and Clarke cite $C$. incrassata from the Warsaw limestone at Warsaw. Furthermore, I have specimens from the Keokuk limestone at Nauvoo, some of which clearly are the same as $C$. incrassata, and others the same as $C$. obmaxima, and yet they vary but little from one another and there can hardly be a doubt that they belong to a single species. With the original citation may be transferred the subsequent identifications of $C$. obmaxima. In the same place also probably belong the large shell figured by Walcott from the Eureka district as $C$. roissyi and the similar one which I recorded under the same name from the Yellowstone National Park. Furthermore, I am now convinced that the compressed and exfoliated shell from the same dis- 
trict which I identified as Athyris lamellosa is a Cliothyridina and probably the same species.

Horizon and locality.-Batesville sandstone, Batesville quadrangle, Ramsey Ferry (station 1234A4); Marshall quadrangle, Granny Mountain (station 7093).

\section{Cliothyridina elegans Girty.}

Plate IV, figure 14.

1910. Cliothyridina elegans. Girty, New York Acad. Sci. Annals, vol. 20, No. 3, pt. 2, p. 223.

Basal Fayetteville shale: Fayetteville quadrangle, Ark.

This species is represented by a single specimen, an internal mold of a ventral valve. The shape is subelliptical and transverse, with fairly distinct shoulders toward the hinge line, below which the margin is somewhat straightened in an oblique direction. The convexity is low, the beak is small, and a mesial sinus is absent. The surface markings are of course not shown, but very obscure concentric striæ are found upon the mold.

The transverse shape, small beak, concentric markings, and undeveloped fold and sinus indicate that this form is not a Composita but a Cliothyridina. It has quite different characters from $C . s u b$ lamellosa and agrees in all determinable points with $C$. elegans.

Horizon and locality.-Batesville sandstone, Batesville quadrangle, Ramsey Ferry (station 1234A4).

\section{COIMPOSITA Brown.}

\section{Composita subquadrata Hall.}

Plate IV, figures 15-16a.

1858. Athyris subquadrata. Hall, Iowa Geol. Survey. Ann. Rept., vol. 1, pt. 2, p. 703 , pl. 27 , figs. $2 a-d ;$ p. 708 , fig. 118 .

Kaskaskia limestone: Chester, Ill.; Crittenden County, Ky.

1877. Athyris subquadrata? Hall and Whitfield, U. S. Geol. Expl. 40th Par. Rept., vol. 4, p. 271, pl. 5, figs. 19, 20.

Wasatch limestone: Snowstorm Hill, near Dry Canyon, Oquirrh Mountains, Utah.

1891. Athyris subquadrata. Whitfield, New York Acad. Sci. Annals, vol. 5, p. 585, pl. 14, figs. 1-3.

Maxwell limestone: Newtonville and Maxville, Ohio.

1893. Seminula subquadrata. Hall and Clarke, New York Geol. Survey, Paleontology, vol. 8, pt. 2, p. 95. (Advance distribution in fascicles.)

Kaskaskia limestone: Chester, Ill.; Crittenden County, Ky.

St. Louis limestone: Spergen Hill, Ind.; Pella, Iowa.

1894. Seminula subquadrata. Hall and Clarke, Introduction to the study of the Brachiopoda, pt. 2, pl. 35, figs. 13, 15.

Chester limestone: Crittenden County, Ky.

St. Louis limestone: Pella, Iowa. 
1894. Seminula subquadrata. Hall and Clarke, New York State Geologist Thirteenth Ann. Rept., for 1893, pl. 35, figs. 13, 15.

Chester limestone: Crittenden County, Ky.

St. Louis limestone: Pella, Iowa.

1895. Athyris subquadrata. Keyes, Missouri Geol. Survey, vol. 5, p. 92. (Date of imprint, 1914.)

Kaskaskia limestone: St. Mary, Mo.

1895. Seminula subquadrata. Hall and Clarke, New York Geol. Survey, Paleontology, vol. 8 , pt. 2 , p. 95 , pl. 47 , figs. $7-9$, 15, 16 ; pl. 84 , figs. $30,31$.

Kaskaskia limestone: Chester, Ill.; Crittenden County, Ky.

St. Louis limestone: Pella, Iowa; Spergen Hill, Ind.

1895. Athyris subquadrata. Whitfield, Ohio Geol. Survey Rept., vol. 7, p. 472, pl. 10, figs. 1-3. (Date of imprint, 1893.)

Maxville limestone: Newtonville and Maxville, Ohio.

1897. Athyris subquadrata. Weller, New York Acad. Sci. Trans., vol. 16, p. 258, pl. 19, fig. 16. (Date of volume, 1898.)

Batesville sandstone: Batesville, Ark.

1903. Seminula subquadrata? Girty, U. S. Geol. Survey Prof. Paper 16, p. 296, pl. 1 , fig. 5 .

Leadville limestone: Leadville district, Colo.

Millsap limestone: Castle Rock quadrangle, Colo.

There is scarcely any Carboniferous genus which is so abundant in individuals, so free in variation, and at the same time so difficult to subdivide into species as the genus Composita. This is partly due to the fact that the variation, though considerable, is yet restricted to shape and that the most remote extremes appear to be connected by all intermediate gradations. It may well be questioned, therefore, whether such types as $C$. trinuclea, $C$. subquadrata, and $C$. subtilita are so much biologic species as stratigraphic species; whether, for instance, $C$. trinuclea and $e^{\gamma}$. subquadrata might not on biologic characters be recognized among the Pennsylvanian forms included under $C$. subtitita.

Compositas are rather rare in the Batesville sandstone, although at one locality, in Batesville itself, they are abundant. One of my figures represents a large, somewhat compressed specimen from Marshall. Allowing for this distortion, I would describe this shell as having a rather spreading shape, with strongly developed fold and sinus. Specimens of $C$. subquadrata from Chester and also Hall's original illustration show a similar species but one which is less strongly plicated, that is, which has the fold less distinctly defined by furrows. In their volume on the brachiopods, however, Hall and Clarke figure a very similar specimen and call it $C$. subquadrata. The strength of the plication suggests $C$. trinuclea, a form in which the development of that feature produces a three-lobed appearance, but typical trinuclea is invariably rather small, perhaps rather more transverse, and as represented by Hall in the volume above mentioned it shows a median groove on the fold, a feature certainly 
not persistent in the species. On the other hand, if this specimen were placed in a series of Pennsylvanian Compositas one would probably fail to distinguish it from $C$. subtilita.

From the same locality (Marshall) I have also a few specimens representing a slightly different form, one in which the fold and sinus are less strongly defined and which is therefore a little closer to typical $C$. subquadrata.

The specimen figured by Weller as $C$. subquadrata was borrowed from the Survey collections and is here refigured for comparison. It apparently is only a small example of the type shown in more fully developed condition in the other illustrations. Other Batesville specimens are similar to it and, as a rule, differ from the Marshall specimen in being somewhat smaller and less strongly plicated.

The large and strongly plicated shell first described may be the form that $\mathrm{I}$ am identifying as $C$. madisonensis in the fauna of the basal Fayetteville shale, while the other specimens may be the form there referred to $C$. subquadrata.

Horizon and locality.-Batesville sandstone, Batesville quadrangle, Ramsey Ferry (station 1234A4), Batesville (station 7699); Marshall quadrangle, Marshall (stations 7090, 7587); Granny Mountain (station 7093a).

\section{Composita acinds Girty.}

Plate IV, figures $\mathbf{1 7 - 1 7 d . ~}$

1910. Composita acinus. Girty, New York Acad. Sci. Annals, vol. 20, No. 3, pt. 2, p. 222.

Basal Fayetteville shale: Fayetteville quadrangle, Ark.

Athyroids are rather rare in the Batesville sandstone and are represented chiefly by the Cliothyridinas. In the limestone at the top of the formation at Round Mountain, near Batesville, a small Composita is, however, rather abundant. It is apparently the form from the Fayetteville shale to which I gave the name Composita acinus. Most specimens are rather narrow and elongate and their comparatively high convexity indicates that they are, in spite of their size, mature. The largest specimen, that selected for illustration, is only 7.5 millimeters long. The ventral valve has a relatively narrow, deep sinus chiefly developed near the front margin. The dorsal valve is without a corresponding elevation and is in fact sometimes slightly depressed along the middle into a small dorsal sinus, a circumstance which produces a slight reentrant angle in the front outline.

Horizon and locality.-Batesville sandstone, Batesville quadrangle, Round Mountain (station 7089). 


\section{EUMETRIA Hall.}

\section{EUMETRIA MARCYI Shumard.}

Plate IV, figures 18-19b.

1852. Terebratula serpentina? (non De Koninck). Owen, Geol. Survey Wisconsin, Iowa, and Minnesota Rept., pl. 3A, fig. 13. (See specimens in U. S. Nat. Mus. Cat. Invertebrate Fossils, 17955.)

Carboniferous: Skunk River, Iowa.

1853. Terebratula marcyi. Shumard, Marcy's Exploration of the Red River,

La., p. 203 , pl. 1, figs. 4a, 4b. (As a Senate Ex. Doc.)

Carboniferous: Washington and Crawford counties, Ark.

1854. Terebratula marcyi. Shumard, Marcy's Exploration of the Red River,

La., p. 177, pl. 1, figs. 4a, 4b. (As a House Ex. Doc.)

Carboniferous: Washington and Crawford counties, Ark.

1858. Retzia Verneuilana. Hall, Albany Inst. Trans., vol, 4, p. 9.

St. Louis limestone: Bloomington and Spergen Hill, Ind.

1858. Retzia verneuilana. Hall, Iowa Geol. Survey Ann. Rept., vol. 1, pt. 2 , p. 657 , pl. 23, figs. 1a-d.

Warsaw limestone: Spergen Hill and Bloomington, Ind.

1858. Retzia vera. Hall, Iowa Geol. Survey Ann. Rept., vol. 1, pt. 2, p. 704, pl. 27, fig. 3a.

Kaskaskia limestone: Chester, Ill.

1858. Retzia vera var. costata. Hall, Iowa Geol. Survey Ann. Rept., vol. 1, vt. 2 , p. 704 , pl. 27 , figs. $3 b, 3 c$.

Kaskaskia limestone: Chester, Ill.

1863. Eumetria vera. Hall, New York State Cab. Nat. Hist. Sixteenth Rept., p. 55 ; figs. 1 and 3 , and p. 59 .

1863. Eumetria verneuili. Hall, idem, p. 55, fig. 2.

1882. Eumetria Verneuilana. Whitfield, Am. Mus. Nat. Hist. Bull., vol. 1, p. 50, pl. 6, figs. 28-30.

St. Louis group: Spergen Hill, Paynters Hill, and Bloomington, Ind.; Alton, Ill.

1883. Eumetria verneuiliana. Hall, Indiana Dept. Geology and Nat. Hist. Twelfth Ann. Rept., for 1883, p. 335, pl. 29, figs. 28-30.

St. Louis group: Spergen Hill, Lanesville, and Bloomington, Ind.

1884. Retzia radialis (pars). Walcott (non Phillips), U. S. Geol. Survey Mon. 8, p. 220 , pl. 7 , figs. $5-5$ d, 5 e (?).

Upper Devonian: Eureka district, Nev.

Lower Carboniferous: Eureka district, Nev.; Little Belt Mountains, near Clendenin, Mont.

1889. Retzia Marcyi. Miller, North American geology and paleontology, p. 366. Kaskaskia group.

1893. Eumetria vera. Hall and Clarke, New York Geol. Survey, Paleontology, vol. 8 , pt. 2, p. 117. (Advance distribution in fascicles.)

1893. Eumetria Verneuiliana. Hall and Clarke, idem, p. 117, figs. 104, 105. (Advance distribution in fascicles.)

1894. Eumetria Verneuiliana. Hall and Clarke, New York State Geologist Thirteenth Ann. Rept., for 1893, pt. 2, pl. 37, figs. 1-4, 6, 10 . (Also published separately as Introduction to the study of the Brachiopoda: Handbook for students.)

St. Louis group: Spergen Hill, Ind. 
1894. Eumetria vera var. costata. Hall and Clarke, New York State Geologist Thirteenth Ann. Rept., pt. 2, pl. 37, figs. 5, 11.

Chester limestone: Chester, Ill.; Crittenden County, Ky.

1894. Eumetria vera. Hall and Clarke, idem, pl. 37, figs. 8, 12.

Chester limestone: Crittenden County, Ky.

1895. Retzia vera. Keyes, Missouri Geol. Survey, vol, 5, p. 95. (Date of imprint, 1894.)

Kaskaskia limestone: St. Mary, Mo.

1895. Retzia verneuiliana. Keyes, idem, p. 95.

St. Louis limestone: St. Louis, Mo.

1895. Eumetria vera var. costata. Hall and Clarke, New York Geol. Survey, Paleontology, vol. 8, pt. 2, pl. 51, figs. 27-33.

Chester limestone: Crittenden County, Ky.; Chester, Ill.

1895. Eumetria vera. Hall and Clarke, idem, p. 117, pl. 51, figs. 36, 37.

Chester group: Crittenden County, Ky.

1895. Eumetria Vernewiliana. Hall and Clarke, idem, p. 117, figs. 164, 105; pl. 51, figs. 13-26, 34, 35; pl. 83, figs. $26,27$.

St. Louis group: Spergen Hill, Ind.; Greene County, Mo.

1897. Eumetria verneuilana. Weller, New York Acad. Sci. Trans., vol. 16, p. 259. (Date of volume, 1898.)

Batesville sandstone: Batesville, Ark.

1899. Eumetria verneuiliana. Girty, U. S. Geol. Survey Mon. 32, pt. 2, p. 560, pl. 68 , figs. $12 \mathrm{a}-12 \mathrm{~b}$.

Madison limestone: Yellowstone National Park.

1903. Eumetria marcyi? Girty, U. S. Geol. Survey Prof. Paper 16, p. 303.

Ouray limestone: San Juan region, Colo.

1904. Eumetria marcyi. Girty, U. S. Geol. Survey Prof. Paper 21, p. 49, pl. 10, figs. 15-17.

Mississippian (Escabrosa limestone) : Bisbee quadrangle, Ariz.

1906. Eumetria marceyi. Beede, Jndiana Dept. Geology and Nat. Res. Thirtieth Ann. Rept., for 1905, p. 1319, pl. 22, figs. 28-30.

Salem limestone: Lanesville, Spergen Hill, Bedford, Bloomington, Paynters Hill, Harrodsburg, Stinesville, and Romona, Ind.

1911. Eumetria marcyi. Girty, U. S. Geol. Survey Bull, 439, p. 77, pl. 8, fig. 10. Moorefield shale: Batesville quadrangle, Spring Creek, Ark.

This species is extremely abundant in the limestones of the upper part of the Batesville at Marshall and it is equally rare there in the sandstones of the same formation. It is very abundant also in the limestone west of Batesville and fairly common in the sandstone too. It was also recorded by Weller, who identified it as Eumetria verneuitiana.

Some specimens attain a considerable size, as much as 20 millimeters in length. They differ in shape, some being slender and elongate, cthers broader and subcircular. Probably in the size of the costæ a fair degree of constancy is maintained, although some specimens look more coarsely ribbed than others. This apparent difference is usually due to the fact that the costæ increase regularly in size from back to front, so that small specimens are actually more finely striated than large ones. A broad shallow undefined sinus is present in some of the ventral valves. 
This is undoubtedly the species which Shumard described as Terebratula marcyi. He states that the number of costæ ranges from 34 to 38. In a specimen the size of his type, having a length of 13 millimeters, there are 39 ribs. The number must vary, however, not only in proportion to size but in proportion to width, the narrower ones naturally having fewer costæ. This is also pretty clearly the form that Hall described as Eumetria vera. Small specimens comparable to the dwarf species which Hall described as Eumetria verneuiliana are slightly, though appreciably more finely ribbed and it is a little doubtful whether that species should be included in the synonymy. It is doubtful, however, whether such differences are constant and important enough to justify retaining verneuitiana and costata even as varieties.

Horizon and locality.-Batesville sandstone, Batesville quadrangle, Spring Creek (station 1248D), Ramsey Ferry (station 1234A4), Batesville (station 7699), Round Mountain (station 7089); Marshall quadrangle, Marshall (stations 7091, 7092, 7092a), Granny Mountain (station 7093).

\section{PELECYPODA.}

\section{SOLENOPSID $A$ E.}

\section{SPHENOTUS Hall.}

\section{Sphenotus washingtonensis Girty.}

Plate VIII, figure 4.

1910. Sphenotus washingtonense. 'Girty, New York Acad. Sci. Annals, vol. 20, No. 3, pt. 2, p. 224.

Basal Fayetteville shale. Fayetteville quadrangle, Ark.

Shell rather large, very transverse, width 38 millimeters and height 16 millimeters. Cardinal line very slightly arcuate, somewhat more than one-half the entire width. Lower border gently concave in the middle and gently convex at the ends, bending upward more decidedly in front than behind. Anterior extremity regularly rounded, somewhat retracted beneath the small, nearly terminal umbo. Posterior extremity doubly truncate, the lower truncation being slightly oblique and the upper one strongly so. The most prominent portion of the posterior outline is close to the base, the junction of the posterior and inferior margins being subangular. The upper portion of the posterior outline is somewhat longer than the lower, straight, and oblique, forming an obtuse angle with the lower portion and a very obtuse angle with the cardinal margin. Convexity moderate, umbonal ridge rather distinct, the shell falling away on either side of it in two more or less planate surfaces. In front of the umbonal ridge is a very broad, shallow constriction, 
which causes the inferior outline to be somewhat emarginate. An indistinct ridge, not visible on the present specimen, can be postulated on the postumbonal slope from the abrupt deflection of the posterior outline.

Though some minor differences can be discerned which, if constant, might make it desirable to regard the present form as varietally distinct, the agreement with $S$. washingtonensis is in the main so close as to indicate that they are probably indeed the same species.

This form is also extremely similar to the Chemung species $S$. contractus but is not closely related to any other American forms of the same age. S. ceolus and Herrick's figure of S. valvutus are perbaps more similar than any others.

Horizon and locality.-Batesville sandstone, Batesville quadrangle, Spring Creek (station 1248D), Round Mountain (station 7089); Marshall quadrangle, Granny Mountain (station 7093a).

\section{Sphenotus vulgaris n. $\mathrm{sp}$.}

Plate VIII, figures $5-7$.

Shell rather small, transverse, the type specimen measuring 20 millimeters in width and 9 millimeters in height. Hinge line straight, about three-fifths of the entire width. Ventral margin parallel to the dorsal, gently convex, more strongly curved at the ends. Anterior outline concave above, strongly convex below. Beak about one-fifth of the width back from the margin. Posterior extremity obliquely truncated. Beak rather small and strongly incurved. Convexity moderate. Umbonal ridge fairly distinct. A broad, shallow constriction crosses the shell from beak to ventral border which it meets well anterior to the middle. Surface marked by a few relatively coarse concentric striæ.

This species resembles Sphenotus? dubia and may prove to be the same, but I have deemed it advisable to keep them distinct provisionally because of the much lower convexity of $S$. vulgaris and the more obliquely truncated posterior outline. It even has an obscure costa on the postumbonal slope. S. vulgaris also closely resembles the Kinderhook species $S$. cylindrica. The largest specimen referred here has a width of 35 millimeters.

Horizon and locality.-Batesville sandstone, Batesville quadrangle, Ramsey Ferry (station 1234A4), Spring Creek (station $1248 \mathrm{D}$ ?).

\section{SpHenotus aff. BRANneri Girty. ${ }^{1}$}

This type is represented by a single specimen, chiefly interesting because it shows the sculpture. Though quite fragmentary, it ap-

1 Girty, G. H., New York Acad. Sci. Annals, vol. 20, No. 3, pt. 2, p. 224, 1910. 
parently has the general outline of $S$. branneri, to which the character of the sculpture clearly allies it. It may, however, be a young example of a form described below as $S$. constrictus.

The shell is very thin. The anterior portion of the valve is missing, but the median portion is marked by fine, sharp concentric liræ, which appear to be intermittent; the segments, set slightly oblique and inosculating, are elevated at the ends into small papillæ that tend to produce very delicate radiating liræ, which are strongly oblique. In fact the detailed sculpture of this part of the shell is very difficult to discern and describe. The fine concentric liræ are distinctly seen, but it is impossible to trace them continuously. The papillæ are also conspicuous and the delicate rows of lines which they form. No distinct umbonal ridge is present, but the postcardinal portion is marked by three or four radiating costæ. The spaces between the costæ are filled by numerous closely arranged, fine, sharply elevated, concentric liræ, which are straight or even gently concave and abruptly change direction at the costa, which are distinct rather on this account than because of their elevation.

Horizon and locality.-Batesville -sandstone, Batesville quadrangle, Round Mountain (station 7089).

\section{Sphenotus cultellus n. sp.}

Plate VIII, figure 3.

Shell rather large, strongly transverse. Width of the type specimen 49 millimeters, height 20 millimeters. Hinge line rather more than half the greatest width. Basal margin moderately convex and parallel to the cardinal line, curving up strongly at both ends. The posterior extremity is obliquely truncated, the outline merging gradually with that of the cardinal border and making an acute angle with the up-curved ventral border. The posterior angle thus formed lies about on the median line. The beak is situated 11 millimeters back from the anterior-extremity, which is somewhat pointed. The outline in front of the beak is concave. The shell is moderately convex, somewhat compressed at the ends. There is no distinct umbonal ridge.

The surface is marked by rather fine, not very. strong, concentric strix, which appear to be confined to the anterior half of the shell.

This species especially recalls Sphenotus naiadiformis and $S$. obliquus of the Waverly group of Ohio. S. naiadiformis has never been figured from authentic specimens, but Herrick ${ }^{1}$ has given figures of three Waverly specimens which he identifies with that species. Herrick's figures show three rather different types of shell, only one

${ }^{1}$ Herrick, C. L., Denison Univ. Sci. Lab. Bull., vol. 3 , pl. 4, fig. 2 ; pl. 9, fig. 3 ; pl. 10 , fig. 2,1888 .

$49778^{\circ}-$ Bull. $593-15-6$ 
of which does $S$. cultellus greatly resemble. This is the one represented in Plate IV, figure 2. The resemblance to S. obliquus is much less strong, one of the more striking differences being the more nearly terminal beaks of obliquus.

Horizon and locality.-Batesville sandstone, Marshall quadrangle, Marshall (stations 7090, 7587).

\section{SPHENOTUS CONSTRICTUS n. sp.}

Plate VIII, figure 2.

Shell rather large, very transverse. Width, 41 millimeters; height about 15 millimeters. Upper and lower margins nearly straight or gently arcuate, slightly contracting toward the front end. Posterior outline rather regularly rounded. Anterior extremity somewhat pointed above and excavated in front of the umbo, which is situated about one-fifth of the greatest width back from the front. The convexity is moderately strong, but there is a broad shallow constriction, which meets the lower border a little in front of the middle. The posterior portions are somewhat compressed.

The postumbonal slope is crossed by four or five slender radiating costæ, the most anterior of which occurs on the umbonal ridge. There are also rather fine concentric striæ made by fascicles of growth lines, which are less conspicuous on the posterior costate portion of the shell.

This species is related to several found in the Carboniferous rocks of America, especially S. nobitis and S. salteri. It is a more slender form than nobilis, while $S$. salteri apparently lacks the constriction.

The generic position of $S$. constrictus is uncertain and it may belong to Sanguinolites.

Horizon and locality.-Batesville sandstone, Marshall quadrangle, Marshall (station 7587).

\section{Sphenotus aff. meslerianus Girty. ${ }^{1}$}

\section{Plate VIII, figure 8.}

A single specimen represents this species. It is somewhat imperfect and is preserved as a mold of the interior. The shape, which is more readily shown by the figure, is characterized by the strongly curved ventral border contracting behind with the straight hinge line, by the truncated posterior extremity, and by the moderately produced anterior extremity, somewhat pointed, and excavated below the beak. The convexity is moderately low and the umbonal ridge is not distinct. Fragments of the shell show that it was rather

${ }^{1}$ Girty, G. H., New York Acad. Sci. Annals, vol. 20, No. 3, pt. 2, p. 225, 1910. 
thick, and marked toward the margin by fine concentric striæ with coarser ones at intervals.

This form is quite similar to one from the Moorefield shale which I provisionally referred to S.? mesterianus. ${ }^{1}$ It also of course resembles typical $S$. mesterianus but is much less convex and has the anterior extremity less strongly produced.

Among more remote species this form especially resembles Sphenotus bicostatus, S. signatus, and S. telamon. S. bicostatus is perhaps the most similar of these. The present form is less obliquely truncated and it may not have the costæ on the postumbonal slope. The same feature may distinguish it from $S$. signatus and $S$. telamon, which are very much alike and which are rather more transverse than the Batesville shell.

Horizon and locality.-Batesville sandstone, Batesville quadrangle, Round Mountain (station 7089).

\title{
GRAMMYSIID $A$.
}

EDIMIONDIA De Koninck.

\section{Edmondia equilateralis Girty.}

\author{
Plate VIII, figures 9, 9a.
}

1910. Edmondia equilateralis. Girty, New York Acad. Sci. Annals, vol. 20, No. 3, pt. 2 , p. 226.

Basal Fayetteville shale: Fayetteville quadrangle, Ark.

This species is represented by a single imperfect specimen, but the characters preserved are sufficient to establish a fairly satisfactory identification. The size is small and the shape rather strongly transverse, broadly and regularly elliptical. The small and strongly incurved beak is close to the anterior end. The convexity is rather high, the surface marked by fine, sharp, rather regular, closely arranged, concentric strix, some of which at intervals are stronger than the rest.

Thus the agreement is seen to be very close with $E$. equilateratis. The only points of variance are that the beak is perhaps not quite so nearly terminal and the shape not quite so transverse. These differences are, however, inconsiderable.

Horizon and locality.-Batesville sandstone, Batesville quadrangle, beyond Spring Creek (station 1248B). 
Edmondia crassa Girty.

Plate VIII, figure 11.

1911. Edmondia crassa (pars). Girty, U. S. Geol. Survey Bull. 439, p. 82, pl. 12, fig. 8 (not fig. 9 ).

Moorefield shale: Batesville quadrangle, Ark.

A single specimen rather smaller than the type has the transverse shape and subcentral beak of typical $E$. crassa. It is almost too imperfect to make the identification secure, but none of the characters shown is incompatible.

Horizon and locality.-Batesville sandstone, Batesville quadrangle, Spring Creek (station 1248D).

EDMONDIA CRASSA var. SYMMETRICA n. var.

Plate VIII, figure 10.

1911. Edmondia crassa (pars). Girty, U. S. Geol. Survey Bull. 439, p. 82, pl. 12, fig. 9.

Moorefield shale: Batesville quadrangle, Ark.

Two shells differing rather strikingly in proportion were originally and I now think mistakenly included under E. crassa in my report on the fauna of the Moorefield shale. One of these was conspicuously transverse and was designated as the type. The other, which was smaller and more circular in shape, it is now proposed to distinguish as a new variety. The width is only about one and one-fourth times the greatest height and the ends are regularly and broadly rounded. The ventral border is slightly flattened in the middle.

The Batesville sandstone collections contain a specimen considerably smaller than that from the Moorefield shale but resembling it greatly in shape. The beak is possibly a little more nearly terminal, but on the whole it would hardly be justifiable to distinguish it as a different species.

This form especially resembles certain species from the Kinderhook. Nothing yet described from the same geologic age resembles it so closely. The Kinderhook species referred to are $E$. nuptialis, $E$. strigillata, and possibly $E$. quadrata. E. depressa from the Waverly and $E$. varsoviensis from the upper Keokuk may also be compared.

Horizon and locality.-Batesville sandstone, Marshall quadrangle, Marshall (station 7092). 


\title{
NUCULIDAE.
}

NUCULA Lamarck.

\section{Nucula rectangula McChesney.}

\author{
Plate VIII, figures 12, 12a.
}

1860. Nucula rectangula. McChesney, Descriptions of new species of fossils from the Paleozoic rocks of the Western States, p. 74. (Date of imprint, 1859.)

Hamilton group: Near Batesville, Ark.

1865. Nucula rectangula. McChesney, Illustrations of new species of fossils from the Paleozoic rocks of the Western States, pl. 7, figures 5a-c.

1868. Nucula? rectangula. McChesney, Chicago Acad. Sci. Trans., vol. 1, p. 40, pl. 7, figures 5a-c. (Date of imprint, 1867-1869.)

Dark-colored Hamilton shales: Batesville, Ark.

1911. Nucula rectangula. Girty, U. S. Geol. Survey Bull. 439, p. 82, pl. 12, figs. 13-17.

Moorefield shale: Batesville quadrangle, Spring Creek; Marshall quadrangle, Marshall, Ark.

'The most perfect of the four specimens referred to this species is the internal mold represented by my figure. In this specimen the cardinal and posterior outlines are nearly straight and perpendicular to one another. The inferior outline is gently convex, strongly contracting with the hinge line anteriorly. The anterior outline is rounded. The posterior end is subangular below. The umbones are almost terminal, rather large, and strongly incurved.

The surface characters are not shown, but on one of the other specimens, which is badly broken, the external surface appears to be almost smooth.

The specimen described above very closely resembles $N$. rectangula, but the resemblance is, perhaps, closer to a specimen which I referred to that species from the Moorefield shale than to the original figures of McChesney. Considerable difference can be observed among the latter, sufficient to suggest a doubt whether he may not have confused more than one species under this title. At all events, it seems highly probable that the present species is common to the Moorefield shale and Batesville sandstone, even if it is not correctly placed with $N$. rectangula.

Horizon and locality.-Batesville sandstone, Batesville quadrangle, Round Mountain (station 7089?); Marshall quadrangle, Granny Mountain (stations 7093? 7093a). 


\section{Nucula shumardiana Hall.}

Plate VIII, figure 13.

1856. Nucula Shumardana. Hall, Albany Inst. Trans., vol, 4, p. 16.

Warsaw limestone: Spergen Hill and Bloomington, Ind.

1882. Nucula Shumardana. Whitfield, Am. Mus. Nat. Hist. Bull, vol, 1, p. 57, pl. 7, figs. 2-6.

Warsaw limestone: Spergen Hill and Bloomington, Ind.

1883. Nucula shumardana. Hall, Indiana Dept. Geology and Nat. Hist. Twelfth Ann. Rept., for 1882, p. 343, pl. 30, figs. 2-6.

[Warsaw limestone]: Spergen Hill, Lanesville, and Bloomington, Ind. 1906. Nucula shumardana. Beede, Indiana Dept. Geology and Nat. Res.

Thirtieth Ann. Rept., for 1905, p. 1333, pl. 23, figs. 2-6.

Salem limestone: Lanesville, Spergen Hill, Harrodsburg, Bloomington, Ellettsville, Romona, and Stinesville, Ind.

This identification chiefly concerns a single specimen preserved as a mold in sandstone which appears to be a Nucula very closely related to if not identical with the species named above. It is small and of low convexity. The cardinal and posterior outlines are nearly straight and make with one another an angle considerably less than a right angle. The remainder of the outline seems to be closed in by an are strongly and regularly curved. Thus the umbones are terminal and the outline both above and at the back passes obliquely downward and forward.

The surface seems to be marked by strong, regular, widely spaced, concentric striæ which give it a banded or undulated appearance.

Hoxizon and locality.-Batesville sandstone, Batesville quadrangle, beyond Spring Creek (station 1248B), Spring Creek (station 1248D).

\section{LEDID $A$.}

LEDA Schumacher.

\section{LEDA PANDORIFORMIs Stevens?}

Plate VIII, figures $15,16$.

1858. Leda pandoraformis. Stevens, Am. Jour. Sci., 2 d ser., vol. 25, p. 262. Carboniferous: Battle Creek, Mich.

1862. Leda bellistriata. Winchell, Acad. Nat. Sci. Philadelphia Proc., vol. 14, p. 419. (Date of imprint, 1863.)

Marshall group: Moscow, Mich.

1865. Leda bellistriata. Winchell, idem, vol, 17, p. 128.

Marshall group: Hillsdale, Mich.

1869. Leda bellistriata. Winchell, Safford's Geology of Tennessee, p. 444.

Immediately above Black shale, Hickman and Maury counties, Tenn.

1870. Leda bellistriata? Winchell, Am. Philos. Soc. Proc., vol. 11, p. 256. (Date of imprint, 1871.)

Waverly group: Tennessee.

1884. Leda Ohioensis. Hall, New York State Geologist Rept. for 1881, pl. 7, fig. 3.

Waverly sandstone: Waverly, Ohio. 
1885. Leda pandoriformis. Hall, New York Geol. Survey, Paleontology, vol. 5, pt. 1, Lamellibranchiata, pt. 2, p. 332 , pl. 47, figs. $49,50$.

Waverly sandstone: Newark, Ohio; Battle Creek, Mich.

As in the case of Leda nuculiformis the fossils from the Batesville sandstone are identified not with the original species from Michigan but with a form from Ohio so identified by Hall. As in the other case so in this it seems rather probable that Hall's identification may be in error. Stevens's description is of a very general character, and the only statement really supporting such an inference is that Stevens calls the beaks nearly central, whereas Hall says that they are at about the anterior third of the shell.

The specimens under consideration are eight in number and all are internal molds except one, which is so broken that its specific identity with the rest is very uncertain. The other specimens also are not only molds but are more or less fragmentary as well, so that their condition is most unsatisfactory. Six of the eight specimens were obtained from a dark sandy limestone occurring at the top of the Batesville sandstone at Round Mountain, west of Batesville (station 7089). These are rather strongly suggestive of the Hamilton species $L$. diversa, or of the Kinderhook species $L$. diversoides, or of the species described from nearly the same locality and horizon, $L$. vaseyana. They are much larger than typical vaseyana, the largest specimen when perfect probably being 18 millimeters in width, and they appear to have the posterior extension rather more attenuate. On the other hand, the umbo appears to be just a little more anterior than represented in Hall's figures of $L$. pandoriformis.

Of the specimens from the two other localities, that from Marshall (station 7092a) is small and too imperfect for satisfactory reference, though it appears to be the same general type of shell as that of the larger collection from Round Mountain. The specimen from Batesville is in a sandstone matrix, and the outlines are perhaps not quite as distinct as might be wished. It is a rather large individual, having a width of 17.5 millimeters, and it appears to be less transverse than the specimen from Round Mountain - to be, in fact, somewhat intermediate between that form and the one here provisionally referred to L. nuculiformis. This specimen also resembles some of the less slender and transverse types figured by Hall as L. diversa.

A satisfactory disposition of the Batesville Ledas is scarcely possible without more numerous and more perfect specimens. Two and possibly three species are clearly present, and it seems rather probable that they will prove to be the same as those found in the underlying Moorefield shale.

Horizon and locality.-Batesville sandstone, Batesville quadrangle, Ramsey Ferry (station 1234A4), Round Mountain (station 7089); Marshall quadrangle, Marshall (station 7092a). 


\section{LEDA NUCULIFORMIS Stevens?}

Plate VIII, figure 14.

1858. Leda nuculaformis. Stevens, Am. Jour. Sci., 2 d ser., vol. 25, p. 262. Carboniferous: Battle Creek, Mich.

1888. Nuculana nuculaformis? Herrick, Denison Univ. Sci. Lab. Bull., vol. 4, p. 45 , pl. 4 , fig. 23 .

Waverly group: Newark, Ohio.

1889. Nuculana nucullaformis? Herrick, Am. Geologist, vol. 3, pl. 2, fig. 23. Waverly group: Newark, Ohio.

1895. Nuculana nuculaformis? Herrick, Ohio Geol. Survey Rept., vol. 7, pl. 16,

fig. 23. (Date of imprint, 1893.)

Burlington: Newark, Ohio.

This identification is made not with the authentic nuculiformis but with the Waverly form, so called by Herrick, regarding which he was himself in doubt and which is almost certainly a different species from the original one of Stevens. The latter is at least a much larger species, twice the size of the Ohio form.

The Batesville shells referred to here are two in number, and the general resemblance to Herrick's figure is striking. One specimen is an internal mold; the other, though retaining the shell, appears to be perfectly smooth, in which respect it differs from the example figured by Herrick and, in fact, from other members of the genus. It may safely be inferred, therefore, that the characteristic striated sculpture has been lost through attrition, an explanation to which the occurrence in an oolitic matrix lends some support.

The distinguishing features of this form are the rather low convexity and the generally rotund or orbicular shape, which results from the exceptionally small development of the posterior or pointed end. The specimen figured has a width of 13 millimeters and a height of 8 millimeters, and the beak, 6 millimeters back from the anterior margin, is nearly central.

Several other species have a similar configuration, especially Leda curta and Leda nasuta, both recorded from the "St. Louis" group. These two species are rather closely related and may prove to be the same. They differ from the form under consideration in being much smaller, less transverse, and in having the umbo less distinctly anterior.

Although some differences exist which may in part be due to the fact that one of the specimens is an internal mold and the other not, it seems rather probable that this is the same form which in the Moorefield shale fauna I identified as $L$. nasuta?

Horizon and locality.-Batesville sandstone, Marshall quadrangle, Granny Mountain (station 7093a). 
YOLDIA Möller.

\section{Yoldia LeVISTRIata Meek and Worthen?}

1860. Leda (Yoldia?) levistriata, Meek and Worthen, Acad. Nat. Sci. Philadelphia Proc., vol. 12, p. 457.

Upper part St. Louis limestone: Waterloo, Monroe County, Ill.

1866. Yoldia? levistriata. Meek and Worthen, Illinois Geol. Survey, vol. 2, p. 282 , pl. 20 , figs. $7 \mathrm{a}, 7 \mathrm{~b}$.

St. Louis group: Waterloo, Monroe County, Ill.

This type is unsatisfactorily represented by four imperfect specimens. It is not certain, indeed, that more than one species is not included among them, for the two specimens from station 7093 are much smaller and slightly more convex than that from station 7093a. They have been referred to Yoldia rather than to Leda because of their low convexity, indistinct umbonal ridge, and slightly depressed umbones.

They resemble $Y$. levistriata, the only Mississippian species referred to Yoldia, ${ }^{1}$ in shape, except that the beak appears to be very slightly more anterior and the posterior side slightly more elongate and attenuate. The surface characters are not shown by my specimens.

Horizon and locality.-Batesville sandstone, Batesville quadrangle, Spring Creek (station 1248D) ; Marshall quadrangle, Granny Mountain (stations 7093, 7093a).

PINNID $A$ E.

SULCATIPINNA Hyatt.

SUlCatTipinna aRKansana Weller.

Plate VII, figure 1.

1897. Pinna arkansana. Weller, New York Acad. Sci. Trans., vol. 16, p. 260, pl. 20, figs. 1, 2. (Date of volume, 1898.)

Batesville sandstone: Batesville, Ark.

My collections from Batesville contain only a few imperfect fragments whose identity with this species is only probable, but among the Marshall material there is an unusually good specimen which is really more perfect than those on which the species was founded. This is a rather long, narrow cuneate shell with nearly straight and slightly diverging upper and lower borders and a posterior outline strongly oblique from above downward and forward, thus making an acute angle with the cardinal border and gradually merging with the ventral outline.

The surface is marked by rather fine and irregular costæ and by fine obscure undulations due to irregular growth.

${ }^{1}$ Worthen's Sanguinolites multistriatus is also probably a Yoldia (Illinois State Mus. Nat. Hist. Bull., No. 2, p. 14, 1884). 
This form is closely allied to S. maxvillensis, as pointed out by Weller, who says that it may be distinguished by the well-defined longitudinal depression just below the hinge line and by the much fainter radiating and concentric plications. The last difference is found also in the Marshall specimen, which is, however, considerably more strongly costate than Weller's figures. The former difference may be due to the fact that the Arkansas specimens are internal molds, whereas that from the Maxville limestone is probably testiferous. The character in question, if I understand the allusion, has to do with a structure along the cardinal margin which is apparently a ligamental groove and which I think must really be present in Whitfield's species. If not, $S$. maxvillensis can hardly be regarded as belonging to the same genus as $S$. arkansana. S. arkansana also resembles $S$. inexpectans Walcott, which I suspect may have come from nearly the same geologic horizon. It is more faintly costate and apparently has a differently shaped posterior extremity, Walcott's figures representing $S$. inexpectans as being almost squarely truncate.

Horizon and locality.-Batesville sandstone, Batesville quadrangle, Ramsey Ferry (station 1234A4); Marshall quadrangle, Marshall (station 7587).

\section{PTERINEID $A$.}

\section{LEPTODESMA Hall.}

LEPTODESMA CARBONIFERUM n. $\mathrm{np}$.

Plate VII, figures 4-6.

Shell rather small, triangular. Hinge line slightly shorter than the width below. Anterior cardinal angle rather broadly rounded. Anterior outline generally straight with a gentle sinus in the upper part, both above and below which the outline is convex. Inferior outline broadly rounded. Posterior outline less strongly oblique to the hinge than the anterior, convex below, straighter above but curving slightly outward below the cardinal angle. Beak strongly anterior but not terminal by reason of the rather large anterior lobe. Convexity in some specimens rather high but depressed posteriorly over the wing and anteriorly over the lobe.

Right valve similar to the left but with lower convexity and less prominent beak.

Surface smooth or having only incremental lines.

This species is distinguished from $L$. spergenense var. robustum in that it is a more spreading shell, is less oblique, and has a lass distinct sinus outlining the posterior wing.

It resembles more or less strongly several Waverly species of Leptodesma, such as Leptodesma (Liopteria) halli, which has a 
smaller anterior lobe, and $L$. ortoni, which has a broader wing and less oblique posterior outline. $L$. torreyi is very similar in shape but, like most Waverly species, is marked by concentric lamellæ, while $L$. carboniferum is nearly if not quite smooth. This marking is so constant a feature of Leptodesma as to be almost a generic character, which fact, together with the not strongly aviculoid outline, suggests that the present form may be a Myalina of the swatlowi group, a point which, however, as yet scarcely requires serious consideration.

Horizon and locality.-Batesville sandstone, Batesville quadrangle, Ramsey Ferry (station 1234A4), Round Mountain (station 7089?), Spring Creek (station 1248D); Marshall quadrangle, Marshall (station 7587).

LEPTODESMA SPERGENENSE var. ROBUSTUM $n$. var.

Plate VII, figures 2-3.

Shell of medium size, very oblique, very transverse. Hinge line nearly as long as the greatest width. Anterior extremity rounded and strongly lobate. Posterior-superior angle produced and alate. The convexity is moderately high, rather abruptly descending to the posterior wing, which is marked off from the body of the shell as though by a groove. The anterior lobe is defined by an oblique constriction, which produced a sinus in the outline. A very strong sinus in the posterior outline defines the wing.

The surface appears to be smooth.

The right valve resembles the left but has a lower convexity and a less prominent umbo.

This form is similar to Pteronites spergenensis but is nearly three times as large and differs perhaps in more vital particulars. It is not very ventricose and subangular along the umbonal ridge, nor does it now retain evidence of having been marked by strong concentric lamellæ. In both particulars, however, the present specimens, which are internal molds, may be misleading.

In view of these differences, real or apparent, and the different faunal association in which they occur, I doubt the propriety of identifying the Batesville specimens with Whitfield's species, though the present course of distinguishing them as a variety is in a measure provisional.

As to generic position, neither the Batesville form nor typical Pteronites spergenensis can rightly be referred to Pteronites. This is shown by the conspicuously different shape and the far from terminal umbones, while in the variety robustum, at least, the shell is inequivalve, in' contrast with Pteronites, which is said to have the valves equal. These types closely simulate Leptodesma in habit but may not prove to belong to that genus when their characters are fully known. They pretty surely do not belong under Pteronites. 
In the calcareous upper phase of the Batesville sandstone west of Batesville this form occurs in my collections as immature or dwarfed individuals, smaller even than typical $L$. spergenensis and much smaller than the specimens from the sandstone. They have the sinus in the outline below the posterior wing less strongly developed and probably represent an immature condition. Some of the very small ones have no appreciable sinus at all and can hardly be distinguished from Myalina.

Fragmentary specimens, and naturally most of those examined are more or less fragmentary, are sometimes difficult to distinguish from some of the Myalinas, especially from $M$. illinoisensis, from which they differ in the more conspicuously and more abruptly flattened posterior wing, more projecting and well-defined anterior lobe, and by the spinelike extension of the cardinal line when that is not broken away. The large anterior lobe and less terminal umbo is a character in which Weller's figure of Myalina arkansana differs from most of the specimens here referred to that species. Should it prove that $M$. arkansana was based in part on an imperfect specimen of this Leptodesma, it would probably be best to restrict the species to the Myalina, even though by so doing it is eliminated from the literature, because the type specimens that belong to Leptodesma must naturally be less perfect than those that are used as the types of $L$. spergenense var. robustum.

Horizon and locality.-Batesville sandstone, Batesville quadrangle, Spring Creek (station 1248D), Ramsey Ferry (station 1234A4), Round Mountain (station 7089); Marshall quadrangle, Marshall (station 7587).

\title{
CONOCARDIIDA.
}

\section{CONOCARDIUMI Bronn.}

\section{Conocardium cuneatum Hall?}

\author{
Plate VII, figures 7, 7a.
}

1856. Conocardium cuneatum. Hall, Albany Inst. Trans., vol. 4, p. 14.

Warsaw limestone: Bloomington and spergen Hill, Ind.

1882. Conocardium cuneatum. Whitfield, Am. Mus. Nat. Hist. Bull., vol. 1, p. 60 , pl. 7 , figs. $24-26$.

Warsaw limestone: Spergen Hill and Bloomington, Ind.

1883. Conocardium cuneatum. Hall, Indiana Dept. Geology and Nat. Hist. Twelfth Ann. Rept., for 1882, p. 345, pl. 30, figs. 24-26.

[Warsaw limestone]: Spergen Hill, Lanesville, and Bloomington, Ind.

1906. Conocardium cuneatum. Beede, Indiana Dept. Geology and Nat. Res. Thirtieth Ann. Rept., for 1905, p. 1327, pl. 23, figs. 24-26.

Salem limestone: Spergen Hill, Bloomington, Harrodsburg, and Stinesville, Ind.

This form, which is represented by a single specimen preserved as a mold in sandstone, especially resembles three species found in the 
Spergen fauna, $C$. carinatum, $C$. meekanum, and $C$. cuneatum. From Hall's descriptions and figures it is difficult to distinguish these three species, even in material from the typical area, but even in the imperfect condition in which the Batesville specimen occurs it is seen to differ from all of them in having the costæ very broad and the striæ very narrow, just the reverse of the relations in the Spergen forms. In another particular also it differs from all the specimens figured by Hall, for the anterior portion is so depressed that it is scarcely visible when the side of the valve is looked at squarely. This peculiarity, though in part inherent, may have been exaggerated by compression. The umbonal ridge is defined by a slight groove on the flattened anterior surface. The funnel is inconspicuous. A narrow portion of the shell along the anterior side is somewhat strongly inflated; but from this portion the shell tapers gradually to the pointed posterior extremity. The costr on the inflated portion are somewhat finer than those on the long posterior wing, where they are coarse and rounded and defined by almost linear striæ. They are crossed by regular, closely arranged, concentric lamellæ. The flattened anterior end is finely and regularly costate.

Horizon and locality.-Batesville sandstone, Batesville quadrangle, Batesville (station 7699).

\section{PTERIID $A$.}

\section{CANEYELLA Girty.}

\section{Caneyelta hopkinsi Weller.}

\section{Plate VII, figures 8-11.}

1897. Pteronites hopkinsi. Weller, New York Acad. Sci. Trans., vol. 16, p. 261, pl. 20, fig. 10. (Date of volume, 1898.)

Batesville sandstone: Batesville, Ark.

1897. Pteronites lavis. Weller, idem, p. 262, pl. 20 , figs. $11,12$.

Batesville sandstone: Batesville, Ark.

Shape more or less semicircular but with the greatest development on the posterior half of the shell. Anterior outline more oblique and less strongly curved than the posterior. The latter is usually straight above, sloping obliquely forward from the postcardinal angle, which does not project as an obscure spine. In some specimens a gentle sinus is developed near the posterior superior angle. Anterior outline slightly emarginate near its junction with the hinge. Hinge line forming the greatest length of the shell. Beaks nearly terminal but having in front of them a small lobe varying in size but usually perceptible.

Convexity moderately high, chiefly localized in the anterior half of the shell, the slope to the front margin being strong. The large wings are flattened and compressed. The umbones are fairly promi- 
nent, small, and strongly incurved. Owing to the emargination below the beaks, partly caused by an upturning of the shell, a considerable opening is left between the two valves at this point.

The sculpture consists of moderately strong, fine regular concentric wrinkles crossed by radiating costæ, varying in strength and somewhat in fineness, which are apt to be more or less flexuous. The costr are chiefly confined to the median portion of the shell and are best developed toward the margin of large specimens. In many specimens, especially those of small size, no costæ can be detected at all and even where visible they vary greatly in number and strength, some specimens having a few very faint ones and others a larger number of much greater strength, with intermediate gradations. Young examples, even of the costate variety, were apparently smooth.

Prof. Weller divided this series of shells into two species, one of which he called Pteronites hopkinsi and the other P. levis, with only this difference- that $P$. levis was smaller than $P$. hopkinsi and without the plicated surface. In view of the facts that the plicated shells were apparently smooth when young, that there is every indication that the costate and apparently smooth shells are connected by intermediate stages, and that preserved as they now are it would be hazardous to state definitely that even the apparently smooth forms were originally without traces of costæ, it seems to me inadvisable to distinguish two species here, and indeed I doubt whether it would be profitable to recognize the smooth shells as a valid variety.

In its generic relations this form appears to belong to the group of fossils for which I proposed the name Caneyella.

Horizon and locality.-Batesville sandstone, Batesville quadrangle, Ramsey Ferry (station 1234A4), Round Mountain (station 7089), Batesville (station 7699?) ; Marshall quadrangle, Marshall (station $7587)$.

\section{MYALINIDAE.}

\section{MYALINA De Koninck.}

Prof. Weller recorded only one species of Myalina from the Batesville sandstone, a new species, to which he gave the name $M$. arkansana. In this paper I have recognized four species, and in addition there are two or three forms too imperfectly known for identification. There can hardly be a doubt that these four species are based on real differences, but there may be a divergence of opinion as to whether the differences are sufficiently important and sufficiently constant for specific discrimination. It appears to be true that the species intergrade to some extent, but it is probable that the difficulty in separating and identifying them is due in large measure to the imperfections in the material rather than to the possession of intermediate characters. The same difficulty is experienced in distin- 
guishing between several rather remotely related genera as they are presented for study in these collections.

The Batesville fauna contains an unusually large number of genera and species having a myaliniform, an aviculiform, or a modioliform shape. These types I have classified generically under the groups Myalina, Leptodesma, Caneyella, and Lithophagus, but it must be understood that in no case has the separation and identification been made on strictly generic characters. This is, however, true of most work dealing with Carboniferous pelecypods. Although the discriminating characters on which reliance is placed are probably adequate, it is often difficult in this material to ascertain whether these characters are really present or not. Many of the Batesville fossils, from the nature of the matrix, are imperfect, indefinite. in outline and sculpture, and distorted by pressure, so that the collections present for study a rather unusual number of specimens which are too good to throw away and yet so poor in one way or another or are so small and presumably immature that it is impossible to assign them not only specifically but even generically. Thus it can readily be perceived that imperfect specimens might resemble Myatina arkansana, Caneyella hopkinsi (youthful and small shells), Leptodesma spergenense var. robustum, and Lithophagus batesvillensis, and yet that it might be impossible to identify them certainly as between two or even three of these types.

\section{Mralina welleriana $n . s p$.}

Plate VI, figures 1, 2.

Shell rather large, triangular, and transverse. Greatest width about one and one-half times the greatest height. Hinge line slightly shorter than the greatest width. Anterior outline gently sigmoidal, making a distinct, rather elongated lobe before rounding inward to the nearly terminal umbo. This margin is directed to the hinge at an angle of about $45^{\circ}$. The posterior outline is rectilinear above, more arcuate below, and curved rather abruptly around the posteriorinferior angle. It makes an obtuse angle with the hinge line, but only slightly obtuse. Convexity high. Umbonal ridge prominent, situated close to the anterior-inferior border, to which it descends abruptly along the posterior two-thirds, but more gradually along the anterior third because of the anterior lobe. It is narrow anteriorly, bending strongly downward to the small incurved beak, dying down posteriorly and spreading out on the posterior-superior side.

Surface apparently marked with only obscure incremental lines and not verv strong varices of growth. 
Among species in the same fauna this is especially comparable to $M$. arkansana. It is, however, a much larger form and is distinguished by the larger posterior wing caused by the less oblique direction of the posterior outline.

$M$. welleriana is manifestly related to the Pennsylvanian species $M$. swallowi and M. wyomingensis. From the latter it differs in being more oblique and transverse. $M$. swallowi varies considerably as identified by different authors. The form now being discussed might almost be regarded as belonging to the same species as one of these identifications of $M$. swallowi. From others it differs in having a more spreading posterior wing and a more distinct posterior superior angle.

Horizon and locality.-Batesville sandstone, Batesville quadrangle, Ramsey Ferry (station 1234A4?), Batesville (station 7699), Sharps Crossroads (station 7700); Marshall quadrangle, Marshall (station 7587), Granny Mountain (station 7093a?).

\section{Mralina ILLinoisensis Worthen.}

Plate VI, figures 4, 5 .

1884. Modiola illinoiensis. Worthen, Illinois State Mus. Nat. Hist. Bull. 2, p. 16.

St. Louis group (oolite) : Monroe County, Ill.

1890. Modiola illinoiensis. Worthen, Illinois Geol. Survey, vol. 8, p. 125, pl. 20, figs. 2, 2a.

St. Louis group (oolite) : Monroe County, Ill.

1897. Myalina arkansana. Weller, New York Acad. Sci. Trans., vol. 16, p. 262, pl. 19, figs. 16, 17. (Date of volume, 1898.)

Batesville sandstone: Batesville, Ark.

1903. Myalina arkansasana? Girty, U. S. Geol. Survey Prof. Paper 16, p. 307.

Ouray limestone: San Juan region, Colo.

Leadville limestone: Leadville district, Colo.

Millsap limestone: Canyon; Pikes Peak quadrangle; and Castle Rock quadrangle, Colo.

Shell rather small, modioliform, very oblique, very transverse. Posterior-superior angle distinct, strongly obtuse. Convexity rather high. Valves compressed toward the hinge and anteriorly, where there is developed a rather large anterior lobe, defined by a constriction which passes obliquely in front of and close to the umbonal ridge and makes a sinus in the anterior outline about one-third its length down from the beaks. Beaks small, strongly incurved, nearly terminal.

Surface nearly smooth but marked over the anterior lobe by fairly strong, fine regular strix, probably due to fasciculation of fine incremental lines which spread out and become obscure as they pass baçkward over the surface. One specimen shows rather obscure sub- 
lamellose growth lines and incremental striæ, becoming stronger and more regular on the anterior lobe and toward the hinge.

Internal structures but little known. A few left valves show what appears to be a delicate linear tooth parallel to the projecting edge of the hinge line and close to it, a feature shown also by one of the type specimens (fig. 16) of Weller's plate. The little groove which results may be a socket for the slender posterior tooth in the right valve or a receptacle for a ligament.

As these fossils come from the same locality and horizon as Weller's Myatina arkansana and agree with it in almost every respect, there can hardly be a doubt that they are properly identified with his species. Few, if any, however, have the anterior lobe projecting so far beyond the umbo as in the larger of his figures. Though this lobe appeared thus to project in a few specimens, a more careful examination showed that the real position of the beak had not been accurately determined. In fact, the average specimen agrees very closely with Worthen's Modiola illinoisensis and I can not but conclude that the Modiola illinoisensis of one author is the Myalina arkansana of the other, and indeed the two descriptions agree verbally in a surprising manner. Weller's figures show a type having a more projecting anterior lobe than Worthen's, but even if his drawing does not slightly exaggerate this feature, it represents it as developed to a distinctly greater degree than is found in my specimens, which are more in accord with Modiola itlinoisensis. After examining the type specimens of $M$. arkansana, a privilege which I owe to the courtesy of Prof. Weller, I am inclined to believe that his figure 16 does slightly misrepresent the relation between the lobe and the umbo, partly by restoring a little more of the lobe than is really necessary and partly because a slight breakage makes the umbo appear a little farther from the front than was probably actually the case.

The proper generic position of this form can not at present be definitely determined, but as between Myalina and Modiola the former is more probably correct, the species appearing to belong to the group of Myalina swallowi, which has always been regarded as belonging to De Koninck's genus.

Horizon and locality.-Batesville sandstone, Batesville quadrangle, Ramsey Ferry (station 1234A4), Spring Creek (station 1248D), Batesville (station 7699).

\section{Myalina mlinoiseñsis var.}

Plate VI, figure 3.

A few specimens associated with $M$. illinoisensis are distinguished by having the anterior extremity narrow and drawn out, with a corre$49778^{\circ}-$ Bull. $593-15-7$ 
sponding diminution in the size of the lobe. The specimens showing this peculiarity are few in number and rather imperfect in preservation and I am somewhat uncertain whether or not they constitute a valid variety. They even show considerable variation among themselves.

Horizon and locality.-Batesville sandstone, Batesville quadrangle, Ramsey Ferry (station 1234A4), Batesville (station 7699).

\section{Myalina monroensis Worthen.}

Plate VI, figures 6, 6a.

1884. Myalina monroensis. Worthen, Illinois State Mus. Nat. Hist. Bull. 2, p. 15.

Oolitic beds of St. Louis group: Monroe County, Ill.

1890. Myalina monroensis. Worthen, Illinois Geol. Survey, vol. 8, p. 127, pl. 20, figs. 10, 10a.

Oolite beds of St. Louis group: Monroe County, IIl.

The shells included in this species are rather small and their shape varies from that of an imperfect triangle to that of an imperfect parallelogram. The variation depends on the extension of the posterior wing, which may be broad, and have an outline which contracts below with the anterior outline, or narrow, and have an outline which is more or less parallel to the anterior outline in the upper part and rounds into it below. The angle formed by the hinge and anterior outline is acute, rather more than $45^{\circ}$. The beaks are small and nearly terminal and they project but slightly beyond the hinge line. The convexity is low, the umbonal ridge indistinct, and the descent on the anterior side gradual and spreading. The surface appears to be smooth.

These shells differ among themselves and, though some are closely similar to, others show departures from Worthen's description and figures. A few have the triangular shape of typical monroensis, but in most the wing appears to be less extended, with a longer portion of the outline parallel to that of the anterior side. In a few specimens the posterior cardinal angle is obscured, so that the shape suggests $M$. meliniformis, though it differs in having a more oblique axis. This appearance, however, is observed especially in shells which have the two valves in conjunction and it is probably due to breakage, that part of the mold being particularly thin.

In some respects this form resembles $M$. elongata, from which it may be distinguished by the lower convexity, the indistinct umbonal ridge, and the absence of an anterior lobe. There is a resemblance also to one of Weller's figures, that of Pteronites levis, but these specimens are more elongate and have on the whole a distinctly dịfferent expression. 
This form is especially characterized by its low convexity, small terminal beaks, and obscure umbonal ridge. The largest specimen referred here has an oblique length of 32 millimeters.

Horizon and locality.-Batesville sandstone, Batesville quadrangle, Ramsey Ferry (station 1234A4), Spring Creek (station 1248D?); Marshall quadrangle, Marshall (stations 7090?, 7587?).

\section{Myalina elongata $n$. $s p$.}

Plate VI, figures 7,8 .

Shell rather small, oblique, elongated. Posterior and anterior outlines oblique, subparallel, rounding together at the base but more gradually on the posterior side than on the anterior. Hinge line straight and making with the anterior outline an angle slightly greater than $45^{\circ}$. The anterior outline, though nearly straight, swells outward a little below the beak so as to form a small though distinct anterior lobe. The convexity is rather high, chiefly developed, as usual, close to the anterior border.

The surface is marked by a few flat-lying lamellose lines, which are rather regularly arranged.

In some specimens, especially those from Batesville, the descent of the shell on the anterior side of the umbonal ridge is very steep or nearly vertical, and this causes the swelling of the lobe to be less conspicuous than if the anterior side were more projecting.

From $M$. arkansana and $M$. welleriana this species is distinguished by being more erect and much less expanded on the posterior wing. It resembles $M$. sanctiludovici, but aside from lacking the extended posterior cardinal angle, which possibly is not a constant feature of $M$. sanctiludovici, it has a distinct anterior lobe.

Horizon and locality.-Batesville sandstone, Batesville quadrangle, Ramsey Ferry (station 1234A4), Spring Creek (station 1248D), Batesville (station 7699); Marshall quadrangle, Granny Mountain (station 7093a).

\section{TRIGONIID A.}

\section{SCHIZODUS King.}

\section{Schizodus batesvillensis Weller.}

Plate IX, figures 1, 2.

1897. Schizodus batesvillensis. Weller, New York Acad. Sci. Trans., vol. 16, p. 266, pl. 20 , figs. 8,9 . (Date of volume, 1898.)

Batesville sandstone: Batesville, Ark.

1911. Schizodus batesvillensis. Girty, U. S. Geol. Survey Bull. 439, p. 88, pl. 12, fig. 5.

Moorefield shale: Batesville and Marshall quadrangles, Ark.

Shell rather large, transversely subovate. Anterior extremity broadly and regularly rounded. Ventral border gently convex, more 
strongly curving upward at the ends. Hinge line straight, somewhat contracting with the ventral border posteriorly, and joining without any very distinct break the upper portion of the posterior outline, which is gently convex and strongly oblique and connects with the lower portion of the posterior outline in a more or less distinct angle situated a little below the middle. The convexity is moderate. The beaks are rather small and lie about one-third the width back from the anterior extremity. The umbonal ridge is ill-defined.

The surface apparently smooth, except near the anterior border, which is marked by fine but regular concentric striæ.

As represented in my collections this species is more abundant at Marshall than at Batesville and it attains a larger size than the type specimens, the largest example being 45 millimeters in transverse diameter. These Marshall specimens agree rather with Weller's figure 9 than his figure 8 in having the posterior extremity less distinctly truncated and the umbo smaller and less prominent. A single imperfect specimen from Batesville, on the other hand, is more like his figure 8.

I can not but regard this species as very closely allied to $S$. arkansanus, from which it is distinguished by being more spreading and less transverse. The striæ on the anterior border are also perhaps slightly finer. There is even some difficulty in assigning certain specimens to one species rather than to the other. A few unusually transverse shells from Marshall have been placed with $S$. arkansanus and, as above noted, a single unusually high specimen from Batesville has been assigned to $S$. batesvitlensis.

This form is more nearly related to $S$. chesterensis than is $S$. arkansanus. It differs in having the beaks smaller and less prominent, in having the posterior extremity broader (in some specimens), and in having the surface distinctly striated near the anterior border.

Horizon and locality.-Batesville sandstone, Batesville quadrangle, Spring Creek (station 1248D?); Marshall quadrangle, Marshall (station 7587).

\section{SCHIZODUS DEPRESSUS Worthen?}

Plate IX, figure 7. (See also figure 13.)

1884. Schizodus depressus. Worthen, Illinois State Mus. Nat. Hist. Bull. 2, p. 11.

Oolite beds of St. Louis group: Monroe County, Ill.

1890. Schizodus depressus. Worthen, Illinois Geol. Survey, vol. 8, p. 109, pl. 18, figs. 8, 8a.

Oolite beds of St. Louis group: Monroe County, Ill.

1897. Schizodus depressus(?). Weller, New York Acad. Sci. Trans., vol. 16, p. 267 , pl. 21, figs. 7,8 . (Date of volume, 1898.)

Batesville sandstone: Batesville, Ark.

Two specimens are provisionally included here. I have discriminated them from the variety abruptus because of the less distinct 
umbonal ridge and more spreading posterior side. One of them may owe this character to compression; the other, which I have figured, is perhaps only an extreme example of the variety abruptus, which tends in some instances to lose its elevated and angular umbonal ridge and to have the narrow posterior side less oblique as well as less abrupt.

Horizon and locality.-Batesville sandstone, Batesville quadrangle, Ramsey Ferry (station 1234A4); Marshall quadrangle, Granny Mountain (station 7093a).

\section{SchIzodus DePressus var. ABRUPTUs n. var.}

Plate IX, figures 8-12a.

Shell rather small (the largest specimen referred here having a width of 23 millimeters), triangular. The width is in excess of the height in varying ratio. The anterior and inferior outlines together make a parabolic curve of considerably less than a right angle, somewhat straightened toward the posterior extremity and broadly curved around the anterior inferior angle. Posterior outline gently arcuate, with a very short hinge line above. Posterior inferior angle acute, distinct. Convexity moderate, most pronounced along the umbonal ridge, which is subangular and set close to the posterior border. From the umbonal ridge the shell descends steeply to the posterior border, which is differently shaped according as the abbreviated posterior portion of the shell is more or less oblique in its descent. Umbones pointed, prominent, and incurved. Surface apparently smooth.

This is clearly the form which Weller identified with Schizodus depressus, but after comparing the Arkansas fossils with Worthen's types, kindly loaned me by the Illinois Natural History Museum, I am disposed to believe that they form a distinct variety. They differ from typical $S$. depressus in being rather more convex and in having a more angular umbonal ridge, from which the shell descends more steeply on the posterior side, giving the outline a more triangular shape. The type specimen of Schizodus? circulus, which I examined at the same time, is quite imperfect, but I believe that it is a Schizodus closely related to $S$. depressus. In fact, it may be regarded as a depressus which has but a slight development of the posterior side, and it probably does not deserve recognition as more than a variety.

The best specimens of $S$. depressus var. abruptus were obtained from the calcareous upper beds of the Batesville sandstone at Round Mountain, but other specimens of larger size and poorer preservation, apparently belonging to the same species, were collected in the sandstones at a number of places. These specimens differ somewhat 
in width, the extremely transverse ones approaching $S$. chesterensis in their proportions, though not in size.

Horizon and locality.-Batesville sandstone, Batesville quadrangle, Spring Creek (station 1248D), Ramsey Ferry (station 1234A4), Round Mountain (station 7089), Marshall quadrangle, Marshall (stations 7090, 7587).

\section{Schizodus dePressus var. circulus Worthen.}

Plate IX, figure 6.

1884. Schizodus circulus. Worthen, Illinois State Mus. Nat. Hist. Bull. 2, p. 11. Oolite beds of St. Louis group: Monroe County, Ill.

1890. Schizodus circulus. Worthen, Illinois Geol. Survey, vol. 8, p. 109, pl. 19, fig. 1.

Oolite beds of St. Louis group: Monroe County, Ill.

One large and one small imperfect and doubtful example are included in this variety. The large example is subcircular in shape, slightly transverse, with the anterior side more largely developed than the posterior, which here has but little of the extended truncated shape characteristic of most species of the genus. The convexity is low, the beak rather small, and the umbonal ridge indistinct, though the shell falls away more strongly on the posterior side than on the anterior. The surface is smooth.

These seem to be the characteristic features of the smaller and quite imperfect shell on which Worthen's Schizodus circulus was based. On the rather incomplete and unsatisfactory evidence available I am inclined to regard that species as only a variety of $S$. depressus.

Horizon and locality.-Batesville sandstone, Batesville quadrangle, Spring Creek (station 1248D) ; Marshall quadrangle, Granny Mountain (station 7093a?).

\section{Schizodus branneriands n. sp.}

Plate IX, figures 5, 5a.

Shell rather small, transversely subovate. Greatest width about one and one-half times the greatest height. Ventral outline moderately convex, less strongly arcuate behind. Anterior extremity projecting, strongly and regularly curved. Hinge line somewhat more than half the greatest width, contracting posteriorly with the ventral outline. Posterior outline straight, somewhat obliquely truncating the shell, making a rather obtuse angle with the dorsal and ventral borders, both of which it joins in a distinct though rounded angle. Convexity high. Beaks rather large, strongly in- 
curved. Umbonal ridge distinct to the posterior inferior angle. Above it the shell is strongly compressed. Surface markings unknown.

I am a little in doubt as to the advisability of introducing a new name for this form, as it looks very much like one of the type specimens of $S$. batesvitlensis. That it is different from the form which I am calling $S$. batesvillensis, and which resembles the other type specimen, there can hardly be a doubt. In my collection that species is largely restricted to the Batesville sandstone at Marshall. A single specimen from Batesville provisionally placed with it may, in fact, be $S$. arkansanus, many examples of which are less transverse than the ones figured here. I am satisfied that S. brannerianus is distinct from either species as identified in this paper, and if Prof. Weller's figure of $S$. batesvillensis (fig. 8) is the same species as $S$. brannerianus, I would say that he had included two distinct forms under S. batesvillensis, provided, of 'course, my identification of that species is correct. In that event, I would propose to restrict $S$. batesvillensis to his figure 9 , which is apparently the same as S. batesvillensis of this report. His figure 8 consequently would go into the synonymy of the present species.

The differences between $S$. brannerianus and the types here referred to $S$. arkansanus and $S$. batesvillensis are rather obvious. $S$. brannerianus is less transverse than the one and more transverse than the other species, with greater convexity, less obliquely truncated posterior extremity, and more convex ventral border. S. brannerianus is not known to possess the sculptured anterior extremity of either species.

The Pennsylvanian form S. ovatus is, to judge by the figures, extremely similar to S. brannerianus, so that, if associated in the same beds, it might be difficult to tell them apart.

Horizon and locality.-Batesville sandstone, Marshall quadrangle, Marshall (station 7091), Granny Mountain (station 7093).

\section{Schizodus arkansanus Weller.}

Plate IX, figures 3, 4.

1897. Allorisma arkansana. Weller, New York Acad. Sci. Trans., vol. 16, p. 265, pl. 21, figs. 4, 5. (Date of volume, 1898.)

Batesville sandstone: Batesville, Ark.

Shell of medium size, very transverse, subovate. Dorsal and ventral borders more or less straight, slightly contracting posteriorly, rounding together almost symmetrically and meeting about midway in an obscure angle. The outline above is subtruncate, with a fairly distinct posterior-superior angle. Anterior extremity regularly and 
strongly rounded. Beak rather prominent, strongly incurved, strongly anterior. Convexity rather high; the valves somewhat compressed posteriorly. Umbonal ridge fairly distinct, traceable to the posterior inferior angle.

Surface smooth, except toward the front, where it is finely and regularly striate.

The shells included here unquestionably belong to Weller's Allerisma arkansanum, but I have removed them to a different genus, Schizodus. It is true that in the absence of knowledge of the hinge structures the evidence for this change is not mandatory, but certain peculiarities of configuration, such as the prominent umbones, the fairly distinct umbonal ridge, the subtruncated posterior extremity and the projecting anterior extremity, as well as the absence of the characteristic large, loose concentric wrinkles over most of the surface, convinces me that the species is not an Allerisma but is probably a not very characteristic Schizodus. Species similar in shape are found in $S$. wheeleri, S. meekanus, S. perelegans, and S. chesterensis. With the exception of $S$. meekanus, all these forms are more transverse. $S$. perelegans has similar sculpture on the anterior extremity. $S$. chesterensis is probably of about the same geologic age, the others mentioned being Pennsylvanian, but, though related, it is clearly a distinct species.

Though it seems fairly certain that this species is not properly a member of the genus Allerisma, to which it was originally referred, and that it is more satisfactorily associated with the American Schizodontes, it is doubtful whether that group as at present constituted does not represent two genera rather than one. The genus Sedgwickia has a configuration comparable to the more transverse types of Schizodus, and moreover has a sculpture consisting of regular concentric striæ, which are peculiar in being restricted to the anterior half of the shell. This configuration and this sculpture are found rather conspicuously in the present species and in S. perelegans, and to a certain extent in $S$. batesvillensis and $S$. brannerianus. The sculpture of $S$. brannerianus is not clearly shown, but the shape, unusually broad behind, is not quite characteristic of Schizodus, and is suggestive of some of the English Sedgwickias.

Horizon and locality.-Batesville sandstone, Batesville quadrangle, Spring Creek (station 1248D), Ramsey Ferry (station 1234A4); Marshall quadrangle, Marshall (stations 7587, 1247A, 7090?). 


\section{PECTINIDAE.}

\section{DELTOPECTEN Etheridge.}

\section{Deltopecten batesvillensis Weller.}

Plate VI, figures 12-15.

1897. Aviculopecten batesvillensis. Weller, New York Acad. Sci. Trans., vol. 16, p. 263 , pl. 20 , figs. 3,4 . (Date of volume, 1898.)

Batesville sandstone: Batesville, Ark.

1911. Deltopecten batesvillensis. Girty, U. S. Geol. Survey Bull. 439, p. 89, pl.11, figs. $1-4$.

Moorefield shale: Batesville quadrangle, Ark.

Shell rather small; length and breadth about equal, the length being in excess in some specimens, the breadth in others. Hinge line long, not much shorter than the greatest width. Axis nearly perpendicular to the hinge line.

The outline of the lower portion of the left valve is circular, contracting regularly above to about one-fourth the shell length below the hinge, then expanding. The upper fourth of the posterior outline is gently and regularly concave. On the anterior side the turn is more abrupt and the outline is sigmoidal, the upper part being somewhat convex. The convexity of this valve is rather high, chiefly developed in the posterior portion of the shell. The anterior wing is abruptly depressed. The somewhat larger posterior wing is also depressed but not abruptly.

Right valves are for some reason much rarer than left valves, and Prof. Weller did not find any at all. The shape is like that of the other, save for the usual deep byssal notch below the anterior ear. The convexity is conspicuously lower and the beak less projecting.

The surface of the left valve is marked by fine radiating costæ, of which some are larger and more prominent than others. The arrangement of the larger ribs among the smaller ones is not strictly regular, although it does not strike the eye as irregular. Frequently the sizes alternate. Sometimes the larger ones stand at wider intervals. Often several series of graduated sizes can be distinguished. Toward the front many of the larger ribs bear a median sulcus, and this is probably what Weller means by saying that they occur in pairs, though he may also have reference to the alternating arrangement. The costæ extend on to the anterior wing, where they appear to be nearly equal, slender, and separated by relatively wide interspaces. On internal molds the costæ of the posterior wing often appear to be obsolete, but they merely become very fine, so that their impression is probably not preserved where the matrix is rather coarse, as it is in the material from Batesville. Fine, closely arranged, concentric lamellæ were present, though traces of them are 
now seldom shown except on the anterior wing, where they were stronger and more conspicuous than on the rest of the shell. They tend to be finer and fainter on the posterior wing.

In the right valve the surface is crossed by fine subequal costæ, which become finer on the posterior wing, but on the small depressed anterior ear only a few fine ones at wide intervals occur. The concentric lamellæ are strongly developed on the wings, as in the left valve.

The internal structures are imperfectly known. A few specimens show a broad, oblique hinge plate as in Deltopecten, to which genus the configuration and sculpture also conform.

In occurrence these Pectens are confined almost exclusively to the sandstone beds of the Batesville sandstone, only two specimens having been collected from the calcareous beds of that formation. Though this is a rather common species, good specimens are rare, the sculpture being in all specimens somewhat obscured, and in most of them largely so. It is therefore difficult and hardly safe to make fine discriminations of species, though the specimens included here suggest possible varietal distinctions. The shells from Marshall are larger and appear to have the costæ finer and more nearly equal than those from Batesville. The evidence suggests, however, that the latter peculiarity may be due to the larger ribs becoming more completely divided than they are in the Batesville form. In the left valve of specimens from Marshall the posterior wing is defined by an angulation of the shell, a feature which is found also in the form at Batesville and which appears to be absent in the specimens from the Moorefield shale referred to this species. These specimens possess some other peculiarities, especially in having coarser ribs on the wings, although this is shown rather when comparison is made with specimens from Marshall, those from Batesville being somewhat obscure over this part of the shell.

Even among themselves the Batesville specimens show considerable variation in the disposition of the ribs. In a few small specimens the larger ribs alone seem to be present. In others a small rib occurs between each pair of larger ones. In still others two or more small ribs may intervene, and the large ones may or may not be divided by a sulcus.

Horizon and locality.-Batesville sandstone, Batesville quad. rangle, Spring Creek (station 1248D), Ramsey Ferry (station 1234A4), Round Mountain (station 7089), Batesville (station 7699), Sharps Crossroads (station 7700); Marshall quadrangle, Marshall (stations 7090, 7587). 


\section{Deltopecten BATESVILLensis var.}

A single rather small specimen from Marshall is distinguished by having the ribs nearly uniform in size, fine, and more or less flexuous. I am not sure that this is really distinct from the other Marshall specimens, which seem to show an appreciable difference from the typical variety at Batesville in the same direction.

Horizon and locality.-Batesville sandstone, Marshall quadrangle, Marshall (station 7587).

\section{Deltopecten sp. $a$.}

Plate VI, figure 16.

The specimens on which this type is particularly distinguished were found at Marshall and are right valves. In a general way they are like the right valves of $D$. batesvillensis from the same locality, but instead of having numerous fine costa they have much fewer and much coarser ribs, which are poorly defined by narrow shallow striæ. The costæ on the posterior wing are much less crowded and the posterior wing itself is defined by an angle or ridge from which the wing is rather abruptly depressed. The latter peculiarity is found also in the associated form referred to $D$. batesvillensis. A single small or fragmentary left valve has a corresponding structure, with an angle where the posterior wing abruptly falls away from the body of the shell, which is narrow, highly vaulted, and strongly incurved. The sculpture is poorly preserved, and does not show conspicuous differences from $D$. batesvillensis. A very fragmentary external mold having a similar angulation shows strongly and regularly alternating ribs, the large ones standing high above the others, of which one or two were intermediate.

These probably constitute a species distinct from $D$. batesvillensis, but I hesitate to give it a new name, as most of the evidence would have to be taken from the right valve alone.

Horizon and locality.-Batesville sandstone, Marshall quadrangle, Marshall (station 7587).

\section{Deltopecten sp. $b$.}

A fragmentary specimen distinguished by the coarseness of its costæ. When complete it may have had a length of as much as 40 millimeters. The ribs are strongly alternating, the largest having a maximum width of 2 millimeters.

Horizon and locality.-Batesville sandstone, Batesville quadrangle, Ramsey Ferry (station 1234A4). 


\section{Deltopecten sp. $c$.}

A single small specimen, which may be only an aberrant form of D. batesvillensis. The length of the imperfect shell is 15 millimeters, and the shape is about the same as that of Weller's species. The distinguishing peculiarity lies in the costæ, which are strong, narrow, abruptly elevated, and separated by intervals of about twice their own width which are flat and do not contain intermediate radii. The costæ are alternating, but toward the posterior side the smaller ones are not developed, so that they stand at intervals of three or four times their own width.

Horizon and locality.-Batesville sandstone, Batesville quadrangle, Ramsey Ferry (station 1234A4).

\section{MODIOLOPSIDAE.}

\section{IMYOCONCHA Sowerby.}

\section{Mroconcha? DUBIA n. sp.}

Shell small, strongly transverse, subovate. Hinge line straight, about two-fifths the greatest width. Inferior outline gently convex, oblique, contracting strongly with the hinge toward the front. Anterior extremity narrow, strongly rounded. Posterior outline subtruncate, gently convex, more strongly curved below, and making a fairly distinct angle with the hinge. Convexity strong. Valves somewhat compressed along the hinge. Umbonal ridge prominent but undefined. Beaks rather large, strongly curved downward and forward, nearly terminal. Surface apparently smooth.

If not an adventitious character, there is on the interior of the right valve a curved ridge or plate just below the beak, which partly defines a large anterior scar. Along the hinge on the inside of the shell is a beveled area or hinge plate.

The generic position of this shell is uncertain. In a general way it resembles associated species referred to Myalina and Leptodesma, but apparently the generic characters forbid a reference to either of these genera. Specifically it resembles Myatina illinoisensis but lacks the lobelike projection in front. A similar difference distinguishes it from Leptodesma carboniferum, and it also appears to be without the alate configuration of the postumbonal region. It possesses some features suggestive of Cardiomorpha, and others which make it comparable to some of the English shells included by Hind under Mytilomorpha, which name he proposes to substitute for the better-known Goniophora.

Horizon and locality.-Batesville sandstone, Batesville quadrangle, Round Mountain (station 7089). 


\section{MYTILID $A$ E.}

\section{LITHOPHAGUS Blainville.}

\section{Lithophagus ? BatesviLLensis Weller.}

Plate VI, figures 9, 10.

1897. Lithophaga? batesvillensis. Weller, New York Acad. Sci. Trans., vol. 16, p. 263 , pl. 20, figs. 14,15 . (Date of volume, 1898.)

Batesville sandstone: Batesville, Ark.

Shell rather small, very transverse. Width about two and onehalf times the greatest height, which occurs a little posterior to the middle. Ventral border nearly straight medially, gradually rounding upward at the ends, more strongly toward the front, which is strongly and regularly rounded. Hinge line straight, making up about half the entire width, contracting rather gradually toward the front with the ventral border. Posterior outline obliquely truncated. The truncation merges with the straight hinge line so completely that no distinct angle is formed. It also merges without break with the ventral border around the strongly arcuate posteriorinferior angle. Beaks small, strongly incurved, nearly terminal, and but slightly projecting. The anterior part of the shell is the most convex, and it is strongly and regularly arched from top to bottom. Posteriorly the convexity dies down and broadens out, and at the same time it becomes unsymmetrical, the posterior-superior portion being broader and more gradually descending. Valves more or less compressed toward the hinge.

The surface is nearly smooth. Sandstone specimens show only a few obscure striæ of growth. Some testiferous examples in calcareous shale show that the test was very thin and marked by extremely fine, closely arranged, regular incremental lines, which are fasciculate and prominent toward the front and more obscure toward the hinge.

The specimens here under consideration belong without question to Weller's Lithophagus batesvillensis, but it is somewhat doubtful whether that species is really distinct from $L$. pertenuis. The difference pointed out by Weller holds true of my specimens, provided Meek and Worthen's figures are accurate and that they represent the normal type.

It is highly improbable that Carboniferous species such as these do really belong to Lithophagus, but being unable to better the generic reference $I$ leave it as it is.

Horizon and locality.-Batesville sandstone, Batesville quadrangle, Ramsey Ferry (station 1234A4) ; Marshall quadrangle, Marshall (stations 7091, 7587?). 


\section{PHOLADELLID $\boldsymbol{A}$.}

ALLERISIMA King.

\section{Allerisma maxvillense Whitfield.}

Plate $\mathrm{X}$, figures 4,5 .

1882. Allorisma Maxvillensis. Whitfield, New York Acad. Sci. Annals, vol. 2, p. 222.

Maxville limestone: Newtonville, Ohio.

1891. Allorisma Maxvillensis. Whitfield, idem, vol. 5, p. 588, pl, 14, figs. 7, 8 .

Maxville limestone: Newtonville, Ohio.

1895. Allorisma Maxvillensis. Whitfield, Ohio Geol. Survey Rept., vol. 7, p. 475, pl. 10 , figs. 7,8 .

Maxville limestone: Newtonville, Ohio.

From the Marshall quadrangle (station 7093) three specimens of Allerisma have been obtained which differ from $A$. walkeri in being smaller (much smaller than the specimen concerned in the following identification), and especially in having the umbones more anterior. The shape of these shells is almost symmetrical, the upper and lower margins being more or less parallel and the ends regularly rounded. The umbones are nearly terminal. The surface is marked by moderately fine concentric plications.

Though one of the specimens is perhaps not quite as transverse as typical maxvillense, the agreement is so close in the main that an identification seems to be justified, at least until contradictory evidence comes to light.

Horizon and locality.-Batesville sandstone, Marshall quadrangle, Granny Mountain (station 7093).

\section{Allerisma walkeri Weller.}

Plate X, figures 1, 2.

1897. Allorisma walkeri. Weller, New York Acad. Sci. Trans., vol. 16, p. 265, pl. 20, figs. 6, 7. (Date of volume, 1898.)

Batesville sandstone: Batesville, Ark.

To this species I am referring only a single specimen, which is in an imperfect state of preservation. It is considerably larger than the type and, perhaps through breakage, somewhat more slender or transverse. When complete it must have been close to 60 millimeters in width and the height was 25 millimeters or more. The umbo is set well back from the anterior extremity (about 17 millimeters). There is a distinct constriction and the concentric plications are strong and coarse.

The specimens figured in this report are the type specimens, which I have examined through the courtesy of Prof. Weller and the 
Walker Museum of Chicago University. The larger of the types has a fairly distinct umbonal ridge, with a second fairly distinct ridge dividing the postumbonal slope. It is this configuration which Prof. Weller describes in the following terms: "Umbonal ridge illdefined or obsolete, often flattened, giving the appearance of two indistinct ridges extending from the beak to the postero-ventral margin." This is an unusual character for Allerisma, to which genus the species with little doubt belongs, and the specimens showing it I believe to be abnormal to that extent.

Horizon and locality.-Batesville sandstone, Batesville quadrangle, Ramsey Ferry (station 1234A4).

\section{Allerisma walkeri var.}

Plate $\mathrm{X}$, figure 3.

A few specimens associated with $A$. neglecta are distinguished chiefly by having the umbo set conspicuously farther from the margin. They are also somewhat more coarsely plicated.

So far as the limited and imperfect material admits of a determination this same form occurs in the fauna of the basal Fayetteville shale, which I have under investigation. Whether this is a distinct species or variety or only an immature form of $A$. walkeri I am unable to decide. It appears at least more probable that this form is a young stage of walkeri than that $A$. neglectum is so.

Horizon and locality.-Batesville sandstone, Batesville quadrangle, Spring Creek (station 1248D), Ramsey Ferry (station 1234A4).

\section{Allerisma neglectum n. $\mathrm{sp}$.}

Plate $\mathrm{X}$, figures $6-8$.

Shell small, transversely subelliptical. Greatest width about twice the greatest height. Width 20 millimeters. Hinge line straight, more than half the width. Ventral margin nearly parallel to the dorsal, or slightly contracting posteriorly, gently convex toward the middle, strongly curved at the ends. Posterior extremity broadly rounded, more or less truncated above. Anterior extremity rather regularly rounded. Beak about one-fourth the width back from the front margin, rather large, and strongly incurved. Convexity moderately high. Umbonal ridge distinct, subangular, defined by the slightly concave character of the postumbonal slope. A broad obscure cincture occurs a little anterior to the middle.

The surface is marked by rather large, strong, somewhat irregular concentric plications, which are obscured posteriorly, especially above the umbonal ridge.

This is a rather abundant species and its uniform size, together with the much finer plications, indicates that it is not merely a youthful con-. 
dition of some other species, such as $A$. walkeri. The shape and position of the umbones suggest $A$. clavatum. The Waverly species A. consanguinatum appears from the description and figures to be almost a counterpart of this, and I am deterred only by the very different faunas with which they are associated from referring them to the same species. It is quite possible, however, that a comparison of specimens would show differences not suggested by Herrick's description and figures. Another similar species is A. maxvillense. It differs, however, both in the figures and in the identification adopted in the present report, in the coarser concentric plications.

Horizon and locality.-Batesville sandstone, Batesville quadrangle, Spring Creek (station 1248D).

\section{PLEUROPHORID $A$ E.}

\section{CYPRICARDELLA Hall.}

Cypricardelua oblonga Hall.

Plate $\mathrm{X}$, figures 9, 10.

1856. Cypricardella oblonga. Hall, Albany Inst. Trans., vol. 4, p. 18.

Warsaw limestone: Spergen Hill and Bloomington, Ind.

1882. Microdon (Cypricardella) oblonga. Whitfield, Am. Mus. Nat. Hist. Bull., vol. 1 , p. 65 , pl. 7 , figs. $30-34$.

Warsaw limestone: Spergen Hill and Bloomington, Ind.

1883. Cypricardella oblonga. Hall, Indiana Dept. Geology and Nat. Hist.

Twelfth Ann. Rept., for 1882, p. 340, pl. 30, figs. 30-34.

[Warsaw limestone] : Spergen Hill, Lanesville, and Bloomington, Ind.

1906. Microdon oblonga. Beede, Indiana Dept. Geology and Nat. Res. Thirtieth Ann. Rept., for 1905, p. 1330 , pl. 23 , figs. 30-36.

Salem limestone: Spergen Hill, Harrodsburg, Bloomington, Ellettsville, Stinesville, and Paynters Hill, Ind.

1905. Cypricardella oblonga. Cockrell, Am. Geologist, vol. 36, p. 330.

Shell small, not very transverse. Greatest width about one and one-half times the greatest height. Hinge line straight, about onehalf the width. Ventral margin gently convex, parallel to the dorsal, rounding upward about equally at the ends. Posterior outline also nearly straight, truncating the shell somewhat obliquely so as to make an obtuse angle above and an acute angle below, both angles rather rounded. Anterior outline projecting, convex below, straight or gently concave for a nearly equal distance above. Beaks small. Convexity moderate; umbonal ridge fairly distinct. Surface marked by more or less strong, coarse, regular concentric striæ.

I have been somewhat in doubt whether to refer this fossil to Cypricardella or to Sphenotus, as the critical generic characters are not shown. It has, indeed, more the proportions of a Cypricardella, for most of the Sphenoti are more transverse. There are a few species, however-species which at least at present rest in the genus Sphe- 
notus-which are as little transverse as the form under consideration, such as Sphernotus (Pleurophorus) monroensis, Sphenotus (Sanguinolites) retusus, and Sphenotus (Sanguinolites) simplex, and of these $S$. monroensis is extremely similar to the form under consideration. It would not surprise me, indeed, to see that species referred to Cypricardella, especially if the smooth surface attributed to it proves to be adventitious. Furthermore, most of the Sphenoti have a more distinct umbonal ridge and a secondary ridge above on the postumbonal slope.

Among the Cypricardellas several species have a shape more or less closely similar to these shells, especially the much larger $C$. connata, and the smaller $C$. oblonga. Not all the specimens of $C . o b$ longa figured by Whitfield are conspicuously smaller, however, and the shape and proportion are so similar that, granted that the Batesville shell is a Cypricardella at all, it seems probable that it belongs to the same species.

Horizon and locality.-Batesville sandstone, Marshall quadrangle, Granny Mountain (station 7093a).

\section{SCAPHOPODA.}

\section{DENTALIID $\boldsymbol{A E .}$}

\section{IAPVIDENTALIUIM Cosmatt.}

\section{Lavidentalium venustum Meek and Worthen.}

1861. Dentalium venustum. Meek and Worthen, Acad. Nat. Sci. Philadelphia Proc., p. 145,

St. Louis limestone: Waterloo, Monroe County, Ill.

1866. Dentalium venustum. Meek and Worthen, Illinois Geol. Survey, vol. 2,

p. 284, pl. 19, fig. 8 .

St. Louis group: Waterloo, Monroe County, Ill.

1903. Plagioglypta venusta. Girty, U. S. Geol. Survey Prof. Paper 16, p. 453.

1909. Lavidentalium venustum. Girty, U. S. Geol. Survey Bull. 377, p. 41, pl. 5, figs. 5, 5a.

Caney shale: Antlers quadrangle, Tishomingo quadrangle, Okla.

A few specimens only represent this species. They are preserved either so as to show the outside, in which case it is hardly possible to make sure that they are Dentalia rather than Orthocerata, or else so as to show the inside, in which case it is impossible to determine to which group of the Dentaliidæ they properly belong. Specimens of the former class show a smooth exterior on which even growth lines are hardly to be distinguished; specimens of the latter class show a straight, elongate, rather rapidly tapering shell, circular in cross section and having the inner cavity uninterrupted by partitions or septa.

The largest fragment is over 35 millimeters long with a diameter at the larger end of 6 millimeters and at the smaller end of nearly 4 $49778^{\circ}-$ Bull. $593-15-8$ 
millimeters. A shell of this size can hardly be the living chamber of an Orthoceras, and it seems fairly safe to combine the two groups of specimens and conclude that the shell is a smooth Dentalium. It then agrees in every distinguishable character with $L$. venustum as found at Spergen Hill and Waterloo.

Horizon and locality.-Batesville sandstone, Batesville quadrangle, Ramsey Ferry (station 1234A4), Round Mountain (station 7089); Marshall quadrangle, Marshall (stations 7092a, 7091?), Granny Mountain (station 7093a).

\section{GASTROPODA.}

\section{PATELLID $\boldsymbol{A}$.}

\section{LEPETOPSIS Whitfield.}

\section{LePeTOPSIS LEVETTEI White?}

1882. Patella levettei. White, Indiana Dept. Geology and Nat. Hist. Eleventh Ann. Rept., for 1881 , p. 359, pl. 39, figs. 4, 5.

Warsaw division of the St. Louis group: Spergen Hill, Ind.

1882. Lepetopsis Levettei. Whitfield, Am. Mus. Nat. Hist. Bull., vol. 1, p. 68, pl. 8, figs. 9-12.

Warsaw limestone: Spergen Hill, Ind.

1883. Lepetopsis Levettei. Hall, Indiana Dept. Geology and Nat. Hist. Twelfth Ann. Rept., for 1882, pl. 31, figs. 8-12.

St. Louis group: Spergen Hill, Ind.

1901. Lepetopsis Levettei. Greene, Contr. Indiana paleontology, pt. 8, p. 70, pl. 23, figs. 34-35.

Keokuk group: Edwardsville, Ind.

1906. Lepetopsis levettei. Cumings, Indiana Dept. Geology and Nat. Res., Thirtieth Ann. Rept., for 1905, p. 1337, pl. 25, figs. 8-12.

Salem limestone: Spergen Hill, Ind.

This type is represented by a single very small specimen preserved as an internal mold. Including a certain amount of restoration at the broken apex, the shell makes a half volution. The section is nearly circular, perhaps somewhat compressed laterally, and the rate of expansion is very rapid, apparently considerably accelerated toward the aperture. At present the shape is not symmetrical, one side being longer than the other, but this may be due to breakage. In view of the fact that the apex is broken and that the specimen is an internal mold, the initial end may have been a closed spiral making a complete turn, and if expanded to the same size the proportions of the lower part would not have been very different from $L$. levettei. At present the shape suggests a Platyceras, but the expansion is considerably more rapid than that of $P$. circularis, which it otherwise resembles. As restored, the diameter of the aperture is about 7 millimeters and the height about 4 millimeters.

Horizon and locality.-Batesville sandstone, Batesville quadrangle, Batesville (station 7699). 


\section{PLEUROTOMARIID A.}

\section{PLEUROTOMARIA Defrance.}

\section{Pleurotomaria arkansana n. sp.}

Plate XI, figures $8,8 a$.

Shell very small, consisting of about six gradually enlarging volutions, elongate-conical. Height somewhat more than twice the greatest breadth. Volutions regularly rounded but slightly embracing. Sutures deep. Umbilicus closed.

On the peripheral portion of the rounded whorls, or just below, two not very prominent revolving liræ seem to represent the locus of the slit band. About halfway between the upper edge of the band and the suture another moderately strong carina is situated, with another finer one still farther toward the suture. The shell below the band is marked by fine, obscure revolving liræ.

Among the figured species from our Carboniferous rocks I am unable to find any which is liable to be mistaken for the present form. There seems to be reason to suspect that the other specimens from this locality are more or less waterworn and it may be that similar causes have modified the characters of the shell described above.

Horizon and locality.-Batesville sandstone, Marshall quadrangle, Granny Mountain (station 7093a).

\section{Pleurotomaria aff. Perhumerosa Meek. ${ }^{1}$}

Plate XI, figures 7, 7a.

This species is represented by a single specimen preserved as a mold of the interior. The size is small; the volutions are about four in number, and they enlarge rather gradually. They are distinguished by having the upper surface broad, flat, and horizontal, joining the sides by an abrupt angle which is very nearly a right angle, though the shell rounds outward slightly just below. The umbilicus is closed. The sculpture, if any, is unknown.

It is impossible to determine whether this form is a Pleurotomaria or some other genus (Macrocheilina?). The determining character of the presence of a slit band can not be ascertained, though some very obscure markings just below the angulation suggest such a structure. If a Pleurotomaria, this shell resembles $P$. inornata and $P$. perhumerosa, especially the latter. It is readily distinguished, however, by its lower spire and by the occurrence of the band below instead of above the angle, if the position of that structure has been correctly determined.

${ }^{1}$ Meek, F. B., Paleontology of eastern Nebraska : U. S. Geol. Survey Nebraska, pt. 2, p. 232 , pl. 4 , figs. $13 \mathrm{a}, 13 \mathrm{~b}, 1872$. 
Horizon and locality.-Batesville sandstone, Batesville quadrangle, Round Mountain (station 7089).

\title{
Pleurotomaria sp.
}

Three imperfect specimens are included under this title, the largest and best preserved of which has a diameter of 6 millimeters. The shape is subglobose, with a low spire and large final whorl.

The volutions are regularly rounded and the suture depressed. Two angular ridges on the periphery seem to show the location of the broad concave slit band. Just below the suture is a row of rather strong nodes and just below these another row of finer ones. The nodes are connected, one above with one below, by low ridges, which are in the nature of fasciculated growth lines that die down and only faintly mark the surface between the band and the lower row of nodes. The surface below the band is marked by these fine growth lines, which become more strongly elevated toward the umbilicus, and by delicate, distantly spaced, somewhat nodose revolving liræ. In the final volution a zone below the suture is considerably elevated and the nodes which help to form it are conspicuously elongated.

This handsome species is almost certainly new, but the quality of my material hardly warrants my describing it as such. The proportions suggest $P$. subglobosa of the Spergen fauna, but the sculpture is different.

Horizon and locality.-Batesville sandstone, Batesville quadrangle, Round Mountain (station 7089).

\section{EUCONOSPIRA Ulrich.}

\section{Euconospira disjuncta Girty.}

\author{
Plate XI, figure 10.
}

1910. Euconospira disjuncta. Girty, New York Acad. Sci. Annals, vol. 20, No. 3, pt. 2, p. 230.

Basal Fayetteville shale: Fayetteville quadrangle, Ark.

The original of this species is distinguished by having a moderately high spire, composed of volutions that do not meet evenly to form a regular cone but overlap, the basal portion projecting slightly beyond the suture. The volutions are strongly angular, the upper external face being nearly flat and the lower surface gently convex. The narrow slit band is peripheral, defined by a strongly projecting carina above and a less prominent carina below. Beneath the lower carina there is a narrow sulcus. The sculpture consists of regular strong fine transverse striæ and probably of revolving liræ, of which only obscure traces remain. 
A single imperfect specimen from the Batesville sandstone agrees with this species in all the characters that can be ascertained, and the identification, all things considered, possesses a high degree of probability.

Horizon and locality.-Batesville sandstone, Batesville quadrangle, Ramsey Ferry (station 1234A4).

\section{Euconosptra sp.}

Two imperfect specimens preserved as molds in sandstone represent this type. In a general way they resemble $E$. disjuncta but have a lower spire and a more regularly conical shape; that is, the upper volution does not project beyond the suture of the lower. The inferior side of the whorls is more planate and more nearly perpendicular to the axis than in E. disjuncta, and the slit band is narrow and does not show the projecting carina and sulcus. The sculpture is not known.

To just what extent these differences may be ascribed to compression and the accidents of preservation I can not say. Apparently this form belongs to a different species from the other and at the same time it presents more the characters of typical Euconospira, to which genus $E$. disjuncta somewhat doubtfully belongs.

Horizon and locality.-Batesville sandstone, Batesville quadrangle, Ramsey Ferry (station 1234A4).

\section{BEMBEXIA Oehlert.}

\section{Bembexia? sp.}

Plate XI, figures 9, 9a.

This type is represented by a number of specimens, all preserved as molds and most of them imperfect, small, or more or less compressed. The most mature of these shells is comparable to E. disjuncta, for which it might hastily be mistaken. The whorls are, however, more rounded, especially on the under side, and the slit band appears to occupy the truncated apex of a narrow peripheral carina, which is defined above and below by grooves. The surface shows traces of fine regular transverse striæ.

Some specimens, which, because of compression, have more or less of the angular appearance of Euconospira disjuncta, have been referred here because of the configuration of the slit band. I have adopted the same course in regard to certain small specimens and on the same evidence. If rightly identified, these small specimens also indicate that the present form, at least in its younger stages, had a lower spire and broader spiral angle than E. disjuncta. One of these small specimens also has the sulci which bound the slit band 
more or less undeveloped and the band itself scarcely elevated above the regular curvature.

This form appears to be a true Bembexia, or at all events is in more close agreement than the two other species, representing one extreme of a series of which the other extreme is found in Euconospira sp. and the intermediate condition in Euconospira? disjuncta. This is true especially of the shape, the detailed characters of the slit band showing distinctive differences. This fact may indicate that after all E.? disjuncta is not intermediate between the genera Euconospira and Bembexia. Indeed, the trend of the evidence in either direction is not clear, owing to the unsatisfactory condition of the specimens.

Horizon and locality.-Batesville sandstone, Batesville quadrangle, Ramsey Ferry (station 1234A4), Batesville (station 7699).

\section{BELLEROPHON'TIDE.}

\section{BELLEROPHON Montfort.}

\section{BellerophoN sublevis Hall?}

1856. Bellerophon sublavis. Hall, Albany Inst. Trans., vol. 4, p. 32.

Warsaw limestone: Spergen Hill and Bloomington, Ind.; Alton, Ill.

1858. Bellerophon sublavis. Hall, Iowa Geol. Survey Ann. Rept., vol. 1, pt. 2, p. 666 , pl. 23 , figs. $15 \mathrm{a}-\mathrm{c}$.

Warsaw limestone: Above Alton, Ill.; Spergen Hill and Bloomington, Ind.

1882. Bellerophon sublavis. White, Indiana Dept. Geology and Nat. Hist. Eleventh Ann. Rept., for 1881, p. 359, pl. 40, figs. 5-7.

Warsaw division of the St. Louis group: Ellettsville, Monroe County, Ind. 1882. Bellerophon sublavis. Whitfield, Am. Mus. Nat. Hist. Bull., vol. 1, p. 89, pl. 8, figs. 6-7.

Warsaw limestone: Spergen Hill, Bloomington, Paynters Hill, and Ellettsville, Ind; Alton, Ill.

1883. Bellerophon sublevis. Hall, Indiana Dept. Geology and Nat. Hist. Twelfth Ann. Rept., for 1882, p. 371, pl. 31, figs. 6-7.

St. Louis group: Alton, Ill.; Spergen Hill, Lanesville, and Bloomington, Ind.

1891. Bellerophon sublcevis? Whitfield, New York Acad. Sci. Annals, vol. 5, p. 592, pl. 14, figs. $20,21$.

Maxville limestone: Newtonville and Maxville, Ohio.

1895. Bellerophon sublavis. Keyes, Missouri Geol. Survey, vol. 5, p. 148. (Date of imprint, 1894.)

St. Louis limestone: St. Louis, Mo.

1895. Bellerophon sublavis? Whitfield, Ohio Geol. Survey Rept., vol. 7, p. 479, pl. 10, figs. 20, 21.

Maxville limestone: Newtonville and Maxville, Ohio.

1897. Bellerophon sublavis. Weller, New York Acad. Sci. Trans., vol. 16, p. 269, pl. 21, fig. 10. (Date of volume, 1898.)

Batesville sandstone: Batesville, Ark.

1897. Bellerophon sublavis. Ulrich, Minnesota Geol. and Nat. Hist. Survey Final Rept., vol. 3, pt. 2, p. 853. 
1902. Bellerophon sublavis. Sardeson, Am. Geologist, vol. 30, p. 304.

Carboniferous: Humboldt, Iowa.

1906. Bellerophon sublevis. Cumings, Indiana Dept. Geology and Nat. Res.

Thirtieth Ann. Rept., for 1905, p. 1360, pl. 25, figs. 6, 7.

Salem limestone: Spergen Hill, Bloomington, Paynters Hill, Ellettsville, Harrodsburg, and Stinesville, Ind.; Alton, Ill.

This species was cited by Prof. Weller in his paper on the fauna of the Batesville sandstone and the specimen which he figured came from the collections of the United States Geological Survey, but it can not now be found.

Bellerophons are abundant at Round Mountain, west of Batesville (station 7089), but they all occur in the form of internal molds. Two of these specimens that have part of the shell adhering without doubt belong to the genus Euphemus, and several others that have somewhat similar configuration have also been provisionally placed in that genus. Others, mostly of much larger size and somewhat different configuration, many of them in fact showing traces of a slit band, have been referred with a proviso equally ample to Bellerophon sublevis. With specimens preserved like these, as internal molds, and more or less deeply broken about the aperture, even a generic identification must necessarily be based on very unsubstantial criteria, and I can not but feel that the disposition of the material here adopted is somewhat arbitrary and might be considerably modified by some one else working over the same collection.

Claypole ${ }^{1}$ cites this species from the Pennsylvanian at WilkesBarre, Pa., almost certainly a wrong identification, for it is not known to occur outside the Mississippian. Very probably it is a young $B$. crassus, or possibly a young Pharkidonotus percarinatus. Heilprin, it will be remembered, cites Bellerophon crassus var. from the same locality and probably the same horizon, and figures as Bellerophon nodocarinatus a shell which almost certainly belongs to Pharkidonotus percarinatus or its variety tricarinatus.

Horizon and locality.-Batesville sandstone, Batesville quadrangle, Round Mountain (station 7089), Batesville (station 7699?); Marshall quadrangle, Marshall (station 7091), Granny Mountain (stations 7093, 7093a).

\section{Bellerophon sp.}

Plate XI, figures $\mathbf{5}-\mathbf{5 b}$.

In my collection this species is found only in the material from Round Mountain, west of Batesville, where it is not uncommon. All the specimens are very small, the largest not exceeding 7 millimeters in diameter. The shape is peculiar for one of the Bellerophons,

${ }^{1}$ Claypole, E. W., Wyoming Hist. and Geol. Soc. Proc. and Coll., vol. 2, pt. 2, p. 246, 1886. 
being unusually compressed, with relatively high flat-sided volutions. In their general aspect these shells are much more suggestive of the Cephalopoda, but the absence of septa and the presence of a rather deep notch on the anterior border indicate their real affinities. The umbilicus is closed.

All the specimens with possibly one exception are internal molds and show traces of neither sculpture nor slit band. The single specimen which seems to retain fragments of the shell appears to be smooth, but this is somewhat doubtful.

In the apparent absence of a slit band (which would be much more apt to show on the internal mold than the sculpture) this form suggests Euphemus and Tropidodiscus, but the shape is more like that of Tropidodiscus. On the other hand, Tropidodiscus usually has a thin shell, while this form has a thick one. I am inclined to think that more complete data will show this form to be a Euphemus, possibly related to Bellerophon nautiloides or $B$. galericulatus.

Horizon and locality.-Batesville sandstone, Batesville quadrangle, Round Mountain (station 7089).

PATELLOSTIUIM Waagen.

\section{Patellostium branneri Weller.}

Plate XI, figure 6.

1897. Bellerophon branneri. Weller, New York Acad. Sci. Trans., vol. 16, p. 269, pl. 21, fig. 9. (Date of volume, 1898.)

Batesville sandstone: Batesville, Ark.

Of this species my collection has one very imperfect specimen, which shows only part of the large apertural expansion. It is entirely without radiating sculpture, being marked only by fine incremental lines and a few obscure undulations. Several internal molds from another locality have also provisionally been placed under this title because of the presence of obscure transverse plications, all the sculpture being lost and the shape of the aperture indeterminable because of breakage.

The figure which I give is an impression made from the very imperfect type specimen, which through the courtesy of the Walker Museum of Chicago University I have had an opportunity to study. The type specimen is an external mold showing the apertural portion of a Bellerophon. Despite the lack of definite knowledge as to the rest of the shell, the flaring shape indicates with reasonable certainty that the genus is Patellostium. The transverse plications, which are a conspicuous feature of this specimen, are also characteristic of Patellostium, but those shells without exception, 
so far as I am aware, are marked also by fine radiating liræ, whereas this specimen apparently is smooth. I am satisfied, however, that it does retain very faint traces of fine revolving liræ, and that the species is probably not abnormal.

Horizon and locality.-Batesville sandstone, Batesville quadrangle, Round Mountain (station 7089?); Marshall quadrangle, Marshall (station 7091).

\section{BUCANOPSIS Ulrich.}

\section{Bucanopsis cancellata Hall?}

1856. Bellerophon cancellatus (non B. cancellatus Hall, 1847). Hall, Albany Inst. Trans., vol. 4, p. 31. (Date of imprint, 1858-1864.)

Warsaw limestone: Bloomington and spergen Hill, Ind.

1877. Bellerophon textilis. Hall, Miller's American Paleozoic fossils, p. 243.

1882. Bellerophon textilis. Whitfield, Am. Mus. Nat. Hist. Bull., vol. 1, p. 90, pl. 8, figs. 4, 5 .

Warsaw limestone: Spergen Hill and Bloomington, Ind.

1883. Bellerophon textilis. Hall, Indiana Dept. Geology and Nat. Hist. Twelfth Ann. Rept., for 1882, p. 371, pl. 31, figs. 4, 5.

St. Louis group: Spergen Hill, Lanesville, and Bloomington, Ind.

1884. Bellerophon textilis? Walcott, U. S. Geol. Survey Mon. 8, p. 257, pl. 18, fig. 18 .

Lower Carboniferous: Eureka district, Nev.

1897. Bucanopsis textilis. Ulrich, Minnesota Geol. and Nat. Hist. Survey Final Rept., vol. 3, pt. 2, p. 854.

1906. Bucanopsis textilis. Cumings, Indiana Dept. Geology and Nat. Res. Thirtieth Ann. Rept., for 1905, p. 1362, pl. 25, figs. 4, 5.

Salem limestone: Spergen Hill, Bloomington, Paynters Hill, Harrodsburg, and Stinesville, Ind.

1911. Bucanopsis cancellata? Girty, U. S. Geol. Survey Bull, 439, p. 93.

Moorefield shale: Batesville quadrangle, Ark.

Two molds in sandstone are provisionally included under this title. They are of rather small size (10 millimeters in diameter) and rather rapidly enlarging shape, and they retain traces of fine revolving striæ and obscure transverse wrinkles. One of them shows the impression of a rather broad slit band. B. cancellatus is the most likely identification for such a form at this horizon, but the identification can not be depended upon.

As is well known, the name of this species, Bellerophon cancellatus, was preoccupied by Hall's own $B$. cancellatus, 1847 , so that it was changed to Bellerophon textitis. Since $B$. cancellatus, 1847, is now the genotype of Protowarthia, and since the present species is a Bucanopsis, it is possible to return to the original designation, which is adopted here.

Horizon and locality.-Batesville sandstone, Batesville quadrangle, Spring Creek (station 1248D), Ramsey Ferry. (station 1234A4). 


\section{EUPHEMIUS IMcCoy.}

\section{Euphemus sp.}

The genus Euphemus is not, I believe, as such recorded from our Mississippian section, but one or two species I know do not occur below the Pennsylvanian. The form under consideration clearly belongs to the genus Euphemus, but its representation in these collections is too unsatisfactory for the erection of a new species. The best specimen is very small, having a diameter of only about 4 millimeters. It is a slender form, the volutions enlarging gradually and leaving a small umbilicus. The aperture flares but slightly and shows a relatively broad, deep slit. The surface is marked by slender revolving liræ, about 24 in number, separated by wide interspaces. There is no slit band.

With the small specimen which shows the characters mentioned I. am provisionally associating a number of internal molds which seem to agree with it in so far as their characters can be ascertained. Some of these specimens are much larger, one even having a diameter of 12 millimeters, but it is impossible to place these molds with any degree of accuracy:

Horizon and locality.-Batesville sandstone, Batesville quadrangle, Round Mountain (station 7089).

\section{EUOMPHALID E.}

\section{EUOMPHALUS Sowerby.}

\section{Eqomphalus simitis Meek and Worthen.}

Plate XI, figure 4.

1861. Straparollus similis. Meek and Worthen, Acad. Nat. Sci. Philadelphia Proc., p. 145. (Date of imprint, 1862.)

St. Louis limestone: Waterloo, Monroe County, Ill.

1866. Straparollus similis. Meek and Worthen, Illinois Geol. Survey, vol. 2, p. 285 , pl. 19 , figs, $4 \mathrm{a}, 4 \mathrm{~b}$.

St. Louis group: Waterloo, Monroe County, Ill.

1891. Straparollus similis. Whitfield, New York Acad. Sci. Annals, vol. 5, p. 589, pl. 14, figs. 9-11.

Maxville limestone: Newtonville and near Maxville, Ohio.

1895. Straparollus similis. Whitfield, Ohio Geol. Survey Rept., vol. 7, p. 476, pl. 10, figs. 9-11.

Maxville limestone: Maxville and Newtonville, Ohio.

1897. Straparollus similis (?). Weller, New York Acad. Sci. Trans., vol. 16, p. 270. (Date of volume, 1898.)

Batesville sandstone: Batesville, Ark.

The collections studied contain a few specimens of Euomphalus that differ considerably in size but belong, nevertheless, to the same 
species, so far as their imperfect condition of preservation permits one to determine. They are characterized by their low spire and the flattening of the upper surface of the whorls in a horizontal plane. These are the characters of Euomphalus similis, a species which Weller also cites from the Batesville sandstone. The small specimen shown by my figure consists of four volutions and has almost exactly the size of the type specimen, with which it also agrees in other characters, so far as they can be ascertained. The largest example referred here has a diameter of 10 millimeters and is nearly twice as large, being about the size mentioned by Weller.

Horizon and locality.-Batesville sandstone, Batesville quadrangle, Ramsey Ferry (station 1234A4), Batesville (station 7699?); Marshall quadrangle, Marshall (station 7091), Granny Mountain (station 7093a).

\section{NERITOPSID $\boldsymbol{E}$.}

\section{NATICOPSIS IMcCoy.}

\section{Naticopsis genevievensis Meek and Worthen.}

1866. Naticopsis Littonana var. genevievensis. Meek and Worthen, Acad. Nat. Sci. Philadelphia Proc., p. 268.

Chester division: Ste. Genevieve County, Mo., and Randolph County, Ill. 1898. Spharodoma littonana var. genevievensis. Weller, U. S. Geol. Survey Bull. 153, p. 575.

This type is represented by a single specimen in a very imperfect state of preservation. "The diameter is about 13 millimeters, the height indeterminate. The most characteristic feature consists of numerous fine costæ or plications, beginning near the suture and extending part way down the side of the shell, where they deteriorate into growth lines. This peculiarity is found in the Pennsylvanian species Naticopsis altonensis and its allies, where it is conjoined with a deep sinuosity of the shell not found in the present specimen. A similar costation near the suture is found in Naticopsis carleyana and in the species which Meek and Worthen described as Naticopsis littonana var. genevievensis.

A thoughtful consideration of Meek and Worthen's description of Naticopsis littonana var. genevievensis leads inevitably to the conclusion that the form is not a Sphrrodoma, as has generally been considered, but a Naticopsis, as indeed the authors definitely state. The erroneous reference to Sphærodoma evidently gained currency from the fact that Natica littonana of Hall is a Sphærodoma and that the variety genevievensis was described as a variety of that species. It seems certain, however, that it should have been described as a variety of Naticopsis carleyana. The mistake was either a clerical error, both species having been described by Hall under the genus 
Natica, or a wrong identification, by which shells actually belonging to Natica carleyana were identified as Natica littonana. Such a mistake might the more readily have occurred as only the descriptions of the species had at that time (1866) been published. At all events, there can scarcely be a doubt that the Spergen shells, with which the large form from Ste. Genevieve County was compared by Meek, belonged to Naticopsis carleyana and not to Sphoerodoma littonana, first, because Meek definitely states that the species is a Naticopsis (though I believe that he had in mind Hall's original reference to Natica rather than any more remote possibility), and, second, because he mentions the discontinuous costæ below the suture, which is a feature of $N$. carleyana but not of S. littonana. His references to the inner lip and to the columella are also corroborative. It seems to be reasonably certain, then, that Naticopsis genevievensis is not a Sphærodoma and that the species with which it was originally compared was Naticopsis carleyana and not Sphcerodoma littonana, so that the name should have originally been written Naticopsis carleyana var. genevievensis.

Keyes puts Naticopsis littonana var. genevievensis Meek and Worthen in the synonymy of Spharodoma littonana, and Weller, recognizing the variety, puts Sphorodoma littonana of Keyes in the synonymy of Sphcerodoma littonana var. genevievensis, but ample reason has already been given for placing the variety genevievensis even in another genus from Sphorodoma littonana, and it is practically certain that Keyes's Sphorodoma littonana was the authentic species.

The reasons set forth by Meek (which really were directed toward Naticopsis carleyana) seem adequate for distinguishing the variety genevievensis, which is here given full specific value. The identification of the very fragmentary specimen from the Batesville sandstone is, however, quite doubtful. It seems to show a more elongated and high-spired shell than would result from an enlargement of typical $N$. carleyana, such as $N$. genevievensis would appear to be.

The species here described as $N$. splendens has a suggestion of the subsutural plications, but it is hardly to be regarded as a young stage of the larger shell because a considerable number of individuals have been found of uniform size belonging to it. N. splendens furthermore apparently has a more transverse shape.

Horizon and locality.-Batesville sandstone, Batesville quadrangle, Round Mountain (station 7089). 


\section{CAPULDAE.}

\section{PLATYCERAS Conrad.}

\section{Platyceras acutirostre Hall?}

1856. Capulus acutirostris. Hall, Albany Inst. Trans., vol. 4, p. 31.

Warsaw limestone: Spergen Hill and Bloomington, Ind.

1858. Capulus acutirostris. Hall, Iowa Geol. Survey Ann. Rept., vol. 1, pt. 2, p. 665 , pl. 23 , figs. 14a, 14b.

Warsaw limestone: Warsaw, Ill., Spergen Hill and Bloomington, Ind.

1866. Platyceras uncum. Meek and Worthen, Acad. Nat. Sci. Philadelphia Proc., p. 264.

Keokuk limestone: Nauvoo, Ill.

1873. Platyceras uncum. Meek and Worthen, Illinois Geol. Survey, vol. 5, p. 516 , pl. 17 , fig. 1 .

Keokuk limestone: Nauvoo, Ill.

1882. Platyceras acutirostris. Whitfield, Am. Mus. Nat. Hist. Bull., vol. 1, p. 67, pl. 8, figs. 13-15.

Warsaw limestone: Spergen Hill, Paynters Hill, Ellettsville, Bloomington, and Crawfordsville, Ind.; Warsaw, Ill.; Tuscumbia, Ala.

1883. Platyceras acutirostris. Hall, Indiana Dept. Geology and Nat. Hist.

Twelfth Ann. Rept., for 1882, p. 370, pl. 31, figs. 13-15.

St. Louis group: Spergen Hill, Lanesville, and Bloomington, Ind.

1890. Capulus acutirostris. Keyes, Am. Geologist, vol. 6, p. 9.

1890. Capulus acutirostris. Keyes, Acad. Nat. Sci. Philadelphia Proc., p. 170.

(Date of imprint, 1891.)

Keokuk limestone and shale: Warsaw and Nauvoo, Ill.

St. Louis limestone: Spergen Hill and Bloomington, Ind.; Tuscumbia, Ala. 1892. Orthonychia acutirostre. Keyes, Am. Geologist, vol. 10, p. 276.

1895. Orthonychia acutirostre. Keyes, Missouri Geol. Survey, vol. 5, p. 190, pl. 54, figs. 2a-c. (Date of imprint, 1894.)

Keokuk limestone and shale: Warsaw and Nauvoo, Ill.

St. Louis limestone: Spergen Hill and Bloomington, Ind.; Tuscumbia, Ala. 1897. Capulus acutirostris. Weller, New York Acad. Sci. Trans., vol. 16, p. 268. (Date of volume, 1898.)

Batesville sandstone: Batesville, Ark.

1906. (Orthonychis acutirostre.) Cumings, Indiana Dept. Geol. and Nat. Res. Thirtieth Ann. Rept., for 1905, p. 1335, pl. 25, figs. 13-15.

Salem limestone: Spergen Hill, Paynters Hill, Ellettsville (Harrodsburg), Bloomington (Stinesville, Romona), and Crawfordsville, Ind.; Warsaw and elsewhere in Illinois; Tuscumbia, Ala.

The sandy limestone at the top of the Batesville sandstone has furnished a single very small specimen of this species. It is somewhat exfoliated but not reduced to an internal mold. The shell is laterally compressed with a subovate section, the narrow end being posterior. The axis is bent so that about half a revolution is made, and it is also somewhat bent laterally so that the apex is turned to the right. This would make the shell to that extent sinistral. The broad anterior side is marked by a few shallow folds, made specially conspicuous by the corresponding contortion of the rather strong growth 
lines. The rate of expansion is moderate, rather more rapid than in the type specimen of $P$. acutirostre, and more like the second specimen figured by Whitfield. The size is much smaller than that of either.

Claypole ${ }^{1}$ has cited "Capulus acutirostris" from the Pennsylvanian of Wilkes-Barre, but his identification is almost certainly in error, for the species is not known above the Mississippian. His citation has therefore been removed to its most probable place, Platyceras parvum.

Horizon and locality.-Batesville sandstone, Batesville quadrangle, Round Mountain (station 7089).

\section{Platyceras sp.}

This type is represented by two specimens from the same locality as Lepetopsis levettei, and of the same character in some respects. One specimen is, however, much compressed, especially on the left side, and has an angulation down the anterior edge. The other has a similar shape but is less flattened on the left side, though the sharply rounded angulation is emphasized there by an ill-defined sulcus. Both specimens are very small and expand very rapidly.

Horizon and locality.-Batesville sandstone, Batesville quadrangle, Batesville (station 7699).

\section{STROPHOSTYLUS Hall.}

\section{Strophostylus aff. carLeyands Hall. ${ }^{2}$}

Plate XI, figures 13, 13a.

Only three specimens have been referred to this species from the Batesville collection, the most perfect of these being shown by the illustration. They are distinguished from the associated form Naticopsis splendens by their lower spire, more rapid and irregular expansion, and by the uniformity of the growth lines, which are not strengthened near the suture.

This appears to be the same species as that from the Moorefield shale, which I distinguished as Strophostylus aff. carleyanus, hence I have employed the same designation in this place, but I no longer regard the form as closely related to carleyanus. The apparent absence of a callus on the inner lip disposes of such a relationship. This is then apparently a new species, but I refrain from introducing a distinctive name in this place in the hope of securing better specimens. It resembles the species which I described as Naticopsis deformis.

${ }^{1}$ Claypole, E. W.., Proc. and Coll. Wyoming Hist. and Geol. Soc., vol. 2, pt, 2, p. 246, 1886.

${ }^{2}$ Hall, James, Albany Inst. Trans., vol. 4, p. 31, 1856 ; Whitfield, R. P., Am. Mus. Nat. Hist. Bull., vol, 1, p. 71, pl. 8, figs. 26, 27, 1882. 
Horizon and locality.-Batesville sandstone, Batesville quadrangle, Round Mountain (station 7089); Marshall quadrangle, Marshall (station 7091).

STROPHOSTYLUS SPLENDENS $\mathrm{n}$. sp.

Plate XI, figures 11-12a.

Shell small, consisting of about three rapidly enlarging volutions. Spire projecting but little above the final whorl. Aperture large, oval, strongly oblique. Umbilicus closed. Surface marked by fine incremental striæ, which are somewhat stronger toward the suture and toward the umbilicus. No callus is developed and the peritreme is incomplete.

This type resembles several small species from the Carboniferous of Nova Scotia (Naticopsis dispassa and $N$. howei), but the descriptions and figures are so inadequate that satisfactory comparisons can not be made and the associated faunas are so different that specific identity is improbable. Naticopsis. (or Strophostylus) nanus of the Pennsylvanian is a similar species, but it has a more gibbous body whorl. One of Whitfield's figures of $N$. carleyana also very much resembles the present species, but the other figure is quite different and moreover shows a well-developed callus, which $S$. splendens lacks. S. splendens also lacks the costæ, which are developed near the suture in S. carleyanus and are shown in all well-preserved specimens.

This species is especially abundant at station 7091, and there as well as at most other localities it is characterized by having a lustrous though not a phosphatic surface. More or less variation in the height of the spire is found in different specimens, the three from station 7089 being perceptibly more high-spired than the type specimens. They are, however, provisionally retained in the same species. Horizon and locality.-Batesville sandstone, Batesville quadrangle, Ramsey Ferry (station 1234A4), Spring Creek (station 1248D?); Round Mountain (station 7089); Marshall quadrangle, Marshall (stations 7091, 7092a); Granny Mountain (stations 7093, 7093a).

\section{PYRAMTDELLID $A$.}

LOXONEMA Phillips.

LoxonEMa? sp.

Several gastropods from Round Mountain, west of Batesville, show an elongate, many-whorled type of shell, such as is commonly referred to Loxonema or Murchisonia. The whorls are rounded and not deeply embracing. The preservation is that of internal molds, but one of the smaller examples retains part of the 
shell, which appears to be smooth. The largest specimen has a diameter of 10 millimeters and the height must have been 25 or 30 millimeters. This specimen has the upper half of the volution very slightly flattened in a direction somewhat oblique to the axis.

The relationship of these shells can not be determined, and it is even somewhat doubtful whether they belong to the same species or not.

Horizon and locality.-Batesville sandstone, Batesville quadrangle, Round Mountain (station 7089); Marshall quadrangle, Marshall (station 7091).

\section{CEPHALOPODA.}

\section{ORTHOCERATID $A$.}

\section{ORTHOCERAS Breyn.}

\section{Orthoceras indiandm Girty.}

Plate V, figures 7, 7a.

1909. Orthoceras indianum. Girty, U. S. Geol. Survey Bull. 377, p. 47, pl. 6, figs. 13, 13a.

Caney shale: McAlester quadrangle, Okla.

Shell small, gradually enlarging. Diameter about 5 millimeters. Section circular. Siphuncle central. Two chambers to a diameter. Surface marked by fine transverse annular striæ, somewhat wider than the ridges which divide them. Five ridges and five striæ occur in 2 millimeters.

The two imperfect specimens which represent this species agree with surprising closeness with the form from the Caney shale named above. The only difference perceptible consists in the fact that the fine annular ridges marking the surface appear to be rather rounded than flat-topped.

Horizon and 7ocality.-Batesville sandstone, Batesville quadrangle, Round Mountain (station 7089).

\section{Orthoceras caneyandm Girty?}

\section{Plate V, figures 9, 9a.}

1909. Orthoceras caneyanum. Girty, U. S. Geol. Survey Bull. 377, p. 45, pl. 6, figs. $7,8$.

Caney shale: McAlester, Antlers, and Stonewall quadrangles, Okla.

A single specimen is included here, a small shell 22 millimeters long, 3 millimeters wide at the large end, and 2.5 millimeters at the small end. The section is circular and the siphuncle central. The chambers differ remarkably in height, being normally about 1 milli- 
meter but occasionally only about 0.5 millimeter. About three chambers occur in a diameter.

The surface is apparently smooth.

This specimen came from the same locality at which the representatives of $O$. indianum were obtained, and the two are much alike in many particulars. The present specimen, however, has the chambers shorter and more irregular and the surface apparently smooth, although this character is more or less doubtful. The other specimens (representing 0 . indianum) show traces of the annulating striæ even when exfoliated, whereas the present one is without such traces when exfoliated and is equally without evidence of sculpture where embedded in rock. If this shell really possessed a striated surface it should be compared with Orthoceras choctawense. As it is, I am provisionally referring it to $O$. caneyanum because of a resemblance to the specimen from the Caney shale represented by figure 8, which, like this one, shows a peculiar inequality in the height of the chambers. The average distance between the septa, however, is appreciably less in the present form.

Horizon and locality.-Batesville sandstone, Batesville quadrangle, Round Mountain (station 7089).

\section{Orthoceras oKawense Worthen.}

1883. Orthoceras Okavensis. Worthen, Illinois Geol. Survey, vol. 7, p. 324. Chester limestone: Okaw bluff, near Red Bud, Randolph County, Ill.

1890. Orthoceras okawense. Worthen, Illinois Geol. Survey, vol. 8, p. 149, pl. 26, fig. 3.

Chester limestone: Near Red Bud, Randolph County, IIl.

This species is represented by an imperfectly preserved specimen occurring as a mold in sandstone and by another fragment. The diameter of the sandstone specimen is about 9.5 millimeters at the larger end and 7 millimeters at the smaller end, and the length is 27 millimeters. The cross section at present is conspicuously elliptical, probably from compression, and the siphuncle is central. The chambers are short, about 2 millimeters high, or four to a diameter.

In all the characters determined there is such close agreement with Worthen's species cited above that no other course is open but an identification, more or less provisional, since the characters of neither form are completely known.

Horizon and locality.-Batesville sandstone, Batesville quadrangle, Ramsey Ferry (station 1234A4); Round Mountain (station 7089).

$49778^{\circ}-$ Bull. $593-15-9$ 


\title{
Orthoceras aff. EUReKense Walcott. ${ }^{1}$
}

\author{
Plate V, figure 8 .
}

1897. Orthoceras eurekensis. Weller, New York Acad. Sci. Trans., vol. 16, pl. 21, figs. 3, 3a. (Date of volume, 1898.)

Batesville sandstone: Batesville, Ark.

The single specimen included here is the one which was previously figured by Prof. Weller, and I am provisionally using the identification suggested by him, though believing that if all its characters were known it would be found to belong to a distinct species.

The size is rather large and the shape rather strongly tapering. The cross section is conspicuously elliptical, a peculiarity which can probably be ascribed to compression. The chambers are rather short, somewhat more than three occurring in a diameter. The siphuncle is approximately central.

Horizon and locality.-Batesville sandstone, Batesville quadrangle, Spring Creek (station 1248D).

\section{Orthoceras sp.}

This species is represented by two imperfect specimens distinguished by the rather large size, the long chambers, and the character of the sculpture. The larger specimen has a diameter of about 18 millimeters, gradually tapering to 14 millimeters in a length of 45 millimeters. The section is clliptical, probably owing to compression. The siphuncle appears to be central. The chambers are about 8 millimeters high, so that two of them occur in a transverse diameter.

The surface was marked by regular fine sharp transverse liræ, 18 or 19 in 5 millimeters.

This is probably a new species, but at present it is not my purpose to introduce a name for it.

Horizon and locality.-Batesville sandstone, Batesville quadrangle, Ramsey Ferry (station 1234A4).

\section{CYCLOCERATID $A$.}

\section{PROTOCYCLOCERAS Hyatt.}

Protocycloceras sp.

The sole representative of this type is a mere fragment, deserving mention as being the only representative of the genus from the Batesville sandstone. The diameter must have been about 15 millimeters and the subangular annulations are 4.5 millimeters apart. No other characters are shown.

Horizon and locality.-Batesville sandstone, Batesville quadrangle, Round Mountain (station 7089). 


\title{
SOLENOCHEILID $A$ E.
}

SOLENOCHEILUS Meek and Worthen.

Solenocheinus? sp.

Plate V, figure 10.

This type, like so many others of the cephalopods, is represented by a single specimen, very imperfect and preserved as an internal mold. The whorls expand rapidly and have apparently a narrow, shallow impressed zone, being, in fact, hardly more than in contact. The cross section must have been distinctly transverse, broadly rounded at the sides, and somewhat flattened across the venter. A faint angle occurs at the sides where the shell turns to descend into the broad umbilicus. There is an obscure structure, a low, narrow ridge running down the middle of the ventral surface, which suggests a marginal siphuncle, and this is the basis for the reference to Solenocheilus. The septa are 2.5 millimeters apart and have a nearly straight course. There appear, however, to be an obscure ventral lobe and two equally obscure lateral lobes, one on each side. These lobes are separated by a pair of saddles, and a second very obscure pair of saddles is situated on the umbilical shoulders. The diameter of the specimen, including part of the chamber of. habitation, is about 23 millimeters.

Horizon and locality.-Batesville sandstone, Batesville quadrangle, Round Mountain (station 7089).

\section{GLYPHIOCERATID $A$.}

\section{GONIATITES De Haan.}

\section{Goniatites choctawensis Shumard.}

\author{
Plate V, figures 4 , 5.
}

1863. Goniatites choctawensis. Shumard, Acad. Sci. St. Louis 'Trans., vol. 2, p. 109.

Coal Measures: Choctaw Nation (Okla.).

1898. Glyphioceras sphoricus (?) Weller, New York Acad. Sci. Trans., vol. 16, p. 271, pl. 21, figs. 1, 2.

Batesville sandstone: Batesville, Ark.

1903. Goniatites choctawensis. Smith, U. S. Geol. Survey Mon. 42, p. 67.

Bend formation: Choctaw Nation (?), Ind. Ter. (Okla.).

1903. Goniatites striatus. Smith (non Sowerby ?), idem, p. 80, pl. 10, figs. $1-11$; pl. 26, figs. 6-13.

Fayetteville shale: Batesville, Ark.

Bend formation: near Lampasas, Tex.

1909. Goniatites choctawensis. Girty, U. S. Geol. Survey Bull. 377, p. 59, pl. 13, figs. 1-11.

Caney shale: Tuskahoma, Antlers, McAlester, Tishomingo, and Stonewall quadrangles, Okla. 
1911. Goniatites choctawensis. Girty, U. S. Geol. Survey Bull. 439, p. 97, pl. 15, figs. 1-7a.

Moorefield shale: Batesville quadrangle, Ark.

Goniatites of the crenistria group are by no means rare in the Batesville sandstone, but their condition is most unsatisfactory. They are preserved as molds and are mostly compressed and worn or broken, so that the shape of the shell and the character of the suture are altered or obscured. The sculpture seems to be retained only on the external mold and to be accompanied by incomplete impressions of the internal suture.

The shape, as well as it can be determined, is compressed spherical. The volutions are deeply embracing and the umbilicus minute. The surface is marked by numerous fine revolving liræ.

In all these characters there is agreement with $G$. choctawensis, which I have identified also in the underlying Moorefield shale. Not only the configuration and sculpture, but the sutural flexures as well, seem to be those of the Moorefield form.

Prof. Weller described a similar shell from the Batesville sandstone and identified it with $G$. sphericus Martin, following Barrois in uniting $G$. crenistria and $G$. sphericus, but differing from him in using the latter name instead of the former. I can hardly doubt that Weller's 'shell and mine are the same, and yet in several points his description does not agree with my material. The specimens which I have examined hardly have the bifid ventral saddle so much extended as in Weller's figure or the first lateral lobes quite so narrow. These differences are not, however, very considerable. In his statement that only nine striæ occur in a quarter of an inch a more material difference may be found, for in the impressions seen by me more than double that number occur in that distance.

In his monograph on American Carboniferous ammonoids Prof. Smith includes G. sphericus among the American species on the strength of Weller's identification mentioned above; but as Weller is using $G$. sphericus in a sense which includes also $G$. crenistria, a species which Smith identifies also at Batesville (in the Moorefield shale) and describes at length, this course seems hardly necessary. The intrinsic probability is high, and such observations as I have been able to make all corroborate it--that the fossils from the Moorefield shale and the imperfectly preserved ones from the overlying Batesville sandstone are the same species. My reasons for employing the specific name proposed by Shumard instead of G. crenistria are given in the report on the fauna of the Moorefield shale.

Horizon and locality.-Batesville sandstone, Batesville quadrangle, Ramsey Ferry (station 1234A4), Spring Creek (station 1248D); Marshall quadrangle, Marshall (stations 7090, 7587). 


\section{GASTRIOCERAS Hyatt.}

\section{Gastrioceras caneyandm Girty.}

Plate V, figures 6, 6a.

1909. Gastrioceras caneyanum. Girty, U. S. Geol. Survey Bull. 377, p. 57, pl. 12, figs. 4-10.

Caney shale: Tuskahoma, Antlers, McAlester, Stonewall, and Tishomingo quadrangles, Okla.

1911. Gastrioceras caneyanum. Girty, U. S. Geol. Survey Bull. 439, p. 102, pl. 14, fig. 6.

Moorefield shale: Batesville quadrangle, Ark.

This species is fairly abundant in one of the Batesville collections, and a single specimen has also come to hand from the vicinity of Marshall. The shape is discoidal. The high flat-sided volutions are strongly embracing but at the same time leave exposed a moderately wide umbilicus. The surface is marked by 36 or more fine revolving liræ and by constrictions which come about four to a volution. The character of the suture is not shown by my specimens.

The identification of this species with $G$. caneyanum seems to me highly probable, although the evidence available is not conclusive. It is clearly the same general type of shell and the striation appears to be about the same. If not compressed, the Batesville form may be slightly more slender and the umbilicus slightly wider. The umbilicus appears somewhat wider in the figured specimen than in some of the others. Either there is appreciable variation in this regard or else in removing the rock from the figured specimen the umbilicus was somewhat enlarged.

The striation seems to be distinctly finer than on the specimen which I figured from the Moorefield shale but not more so than in other Moorefield specimens, and the umbilicus of the figured Batesville specimen, though not that of other specimens from Batesville, is a trifle larger than that of the figured Moorefield specimen.

Horizon and locality.-Batesville sandstone, Batesville quadrangle, Ramsey Ferry (station 1234A4); Marshall quadrangle, Marshall (station 7091).

\section{ADELPHOCERAS Girty.}

\section{Adelphoceras mesleriandu Girty?}

1909. Adelphoceras meslerianum. Girty, U. S. Geol. Survey Bull. 377, p. 66, pl. 12, figs. 1-3c.

Caney shale: McAlester, Antlers, and Tishomingo quadrangles, Okla.

1911. Adelphoceras meslerianum? Girty, U. S. Geol. Survey Bull. 439, p. 104, pl. 14, figs. 5-5b.

Moorefield shale: Batesville quadrangle, Ark.

A single specimen, imperfect, small, and probably immature, is all that my collection contains of this interesting species. The whorls 
are highly evolute, trapezoidal in cross section, widest over the broad ventral surface, and rather strongly contracting from the sharp ventrilateral shoulder toward the axis. The ventral and lateral surfaces are gently convex. The ventral surface of the mold is marked by a narrow, strong median furrow. The ventrilateral shoulders are crossed by plications or costæ, which extend onto the surfaces of the venter and sides, where they are much less distinct. On the venter their direction is rather strongly retral, but on the sides it is nearly transverse, tending to be somewhat curved, with the convexity outward.

In a general way this form strongly suggests the early stages of A. meslerianum ${ }^{1}$ which I figured from the Caney shale of Oklahoma. In that form, however, the ventral surface of the mold has no median sulcus and the ventrilateral shoulders are marked by nodes which do not extend onto the sides and venter as costæ, nor are they oblique. It is to be remembered, however, that these observations rest in both cases on single specimens.

Horizon and locality.-Batesville sandstone, Batesville quadrangle, Round Mountain (station 7089).

\section{APTYCHUS Meyer.}

Aptychus solidum n. sp.

Plate VIII, figures 1, 1a.

The shape of this problematic organism is oval or operculiform. For purposes of description the pointed end may be called lower and the rounded end upper. Only one side of the organism is known.

The curve of the upper and right-hand margins is symmetrical, but on the left, just above the middle, the outline suddenly rounds inward for a short distance and then proceeds in almost a right line to the apex of the lower end. The only side observed is gently but irregularly convex. The configuration of this surface is difficult to describe. The greatest elevation is central; the most depressed portion lies in the upper half, which is slightly concave. Of the lower half, the left-hand quadrant is also rather depressed and the right-hand somewhat elevated. The two quadrants are rather sharply defined from one another and a low ridge divides the upper quadrant of the left-hand side from the lower. The surface is marked by fine obscure irregular concentric wrinkles, which do not occur to any extent on the left-hand side of the specimen, being replaced by fine irregular striæ resembling growth lines. The right-

1 Girty, G. H., The fauna of the Caney shale of Oklahoma : U. S. Geol. Survey Bull. 377, pl. 12, figs. $3,3 a, 3 b, 1909$. 
hand side of the specimen appears to be quite thin, but the thickness gradually (?) increases to the other side, which at the most projecting point has a thickness of over 1 millimeter. The substance of which the organism is composed seems to be calcite.

There can scarcely be a doubt that this singular object is not itself an organism but part of some other organism. Its shape suggests that it is of the nature of an operculum. On this criterion it might be one valve of the aptychus of a cephalopod, but it might also with equal probability be the operculum of a gastropod. The massive conformation and calcareous composition, however, are abnormal for the opercula of gastropods, and large gastropods are almost unknown at this horizon. Goniatites are, however, rather abundant and on this account the object is provisionally referred to the cephalopods.

Horizon and locality.-Batesville sandstone, Batesville quadrangle, Round Mountain (station 7089).

\section{TRILOBITA.}

\section{PROETID $A$.}

\section{GRIFFITHIDES Portlock.}

\section{Griffithides mucronatus Girty.}

1910. Griffithides mucronatus. Girty, New York Acad. Sci. Annals, vol. 20, No. 3 , pt. 2, p. 238.

Basal Fayetteville shale: Fayetteville quadrangle, Ark.

This species is represented in my collections chiefly by pygidia, but there is also a fragmentary cranidium. Both parts agree in almost every respect with those of $G$. mucronatus.

The pygidium is triangular, broader than long, and strongly convex, the pleural portion rising sharply and strongly above the wide, nearly horizontal border, and the axis rising still more sharply and strongly above the pleural portion.

The axis is divided into 15 annulations, which are sharply defined on the crest and more depressed and ill defined on the sides, where they are deflected and assume a more backward direction. A slight groove at the point of deflection helps to define the upper from the lateral surfaces of the axis.

The pleural portions are somewhat flat above and more abruptly rounded at the sides. They are marked by nine segments, which are increasingly oblique as they approach the posterior end. At the anterior end they are continuous with those of the axis, but they grow more discrepant posteriorly, so that the five last segments of the axis have no pleural segments corresponding to them.

The broad, flat border is well defined from the pleural portion both by the upward spring of the latter and by the abrupt termination of the pleural segments. 
In one specimen the pleural segments are covered by fine papillæ. The same markings appear on the crest of the axis but not on the sides. Each of the segments on the crest of the axis is marked by a row of small tubercles interspersed among the papillæ or alternating with them. In a pygidium from station 7089 the pleural segments have the appearance of being marked by small pits instead of by papillæ, the pits probably representing the broken papillæ.

The cranidium is too imperfect for description.

Horizon and locality.-Batesville sandstone, Batesville quadrangle, Ramsey Ferry (station 1234A4), Batesville (station 7699), Round Mountain (station 7089); Marshall quadrangle, Marshall (station 7092a, 7587).

\section{OSTRACODA.}

\section{LEPERDITIID $A$ E.}

PARAPARCHITES Ulrich and Bassler.

Paraparchites nicklesi Ulrich.

Plate XI, figure 2.

1891. Leperditia nicklesi. Ulrich, Cincinnati Soc. Nat. Hist. Jour., vol. 13, p. $200, \mathrm{pl} .18$, figs. 1a-e.

St. Louis group: Columbia, Monroe County, Ill.

1911. Paraparchites nicklesi. Girty, U. S. Geol. Survey Bull. 439, p. 105, pl. 9, figs. 2-5.

Moorefield shale: Batesville quadrangle, Ark.

Shell rather large, subovate; greatest width about one and one-half times the height; hinge line about one-half the width; anterior and posterior ends projecting, the posterior higher than the anterior, an arrangement which gives the shell a distinct backward swing. The valves are slightly compressed posteriorly. The left valve projects above the right and the right valve projects below the left, the edge being folded inward so that the margin of the shell is interior to its outline. The right valve also overlaps the smaller left valve from cardinal angle to cardinal angle. The left valve has a small spine near the superior anterior angle, but the right valve has no structure to correspond. The surface is finely punctate.

Width 1.5 millimeters, height 1 millimeter.

This shell has slightly different proportions from the type specimen of $P$. nicklesi, being distinctly larger and very slightly wider, but the resemblance is so close in other particulars that the identification seems fairly reliable. On the other hand, it is very doubtful whether $P$. nicklesi is really distinct from $P$. carbonaria. It has proportions very like those of $P$. carbonaria but is said to differ in having the spine. Now a suite of specimens from Stinesville, Ind., some of which undoubtedly belong to $P$. carbonaria, shows this feature in varying degree. In some it is a strong stout spine, in others merely 
an elevated point, and in still others no trace of this structure could be discovered. Practically all gradations seem to exist between the typical carbonaria without a spine, and typical nicklesi with one. It would then seem that nicklesi could be no more than a variety of carbonaria.

Horizon and locality.-Batesville sandstone, Batesville quadrangle, Round Mountain (station 7089) ; Sharps Crossroads (station 7700 ?) ; Marshall quadrangle, Marshall (station 7091).

\section{BEYRICHIID $A$.}

\section{PRIMITIA Jones and Hall.}

\section{Primitia fayettevillensis Girty.}

1910. Primitia fayettevillensis. Girty, New York Acad. Sci. Annals, vol. 20, No. 3, pt. 2, p. 232.

Basal Fayetteville shale: Fayetteville quadrangle, Ark.

Shell small, width, 0.67 millimeter; height, 0.4 millimeter. Shape transversely elliptical, projecting in front; more strongly projecting behind, where also the height is somewhat greater. Left valve lapping over the right along the anterior, ventral, and posterior borders. Convexity high. Sulcus represented by a deep indentation strongly posterior to the center. It is more in the nature of a pit and does not extend to the hinge line.

A comparison of the two specimens from the Batesville sandstone with the type of $P$. fayettevillensis leaves little doubt that they belong to the same species. It should be noted, however, that Primitia is described as having an equivalve shell, while one of the specimens shows that in this species the left valve overlaps the right very distinctly.

Horizon and locality.-Batesville sandstone, Batesville quadrangle, Round Mountain (station 7089) ; Marshall quadrangle, Marshall (station 7091).

\section{Primitia seminalis Girty.}

1910. Primitia seminalis. Girty, New York Acad. Sci. Annals, vol. 20, No. 3, pt. 2, p. 233.

Basal Fayetteville shale: Fayetteville quadrangle, Ark.

There is in my collection but a single ill-preserved representative of this form. The characters, so far as they can be made out, are as follows: The shape is ovate and strongly transverse, with a width of about 0.73 millimeter and a height of about 0.3 millimeter. The upper margin is straightened to form a hinge line of indefinite length, which converges with the inferior margin toward the front. In spite of its broken condition, the shell seems to be flattened at the ends to form a distinct border. Posterior to the middle there is a moderately large and deep pitlike depression, which does not extend as a groove to the cardinal margin. 
This specimen agrees rather closely with typical $P$. seminalis in all characters save one, the median pit, which is distinctly larger and deeper, but as it is shown in this specimen on the internal mold, the shell itself having been broken away, this difference may be explained.

Horizon and locality.-Batesville sandstone, Batesville quadrangle, Round Mountain (station 7089).

\section{GLYPTOPLEURA Girty.}

\section{Glyptopledra rhomboidalis n. $\mathrm{sp}$.}

Plate XI, figure 3.

Shell small, rhomboidal. Width, 0.76 millimeter; height, 0.42 millimeter. Upper and lower margins nearly straight and parallel. Anterior and posterior margins also nearly straight and parallel, making an angle of about $60^{\circ}$ with the upper and lower margins, respectively. The four angles are rounded, the posterior inferior angle much more broadly than the anterior superior angle. The convexity is moderate and regular. A groove passing around three sides of the shell defines a fairly broad oblique border. Within this groove the surface is marked by a number of subangular ridges, which either bend or bifurcate so that they become confluent here and there and thus divide the surface into many facets or compartments. One of these, somewhat distinguished from the rest by its rounded shape and central position, may be an umbilical pit.

This species is most closely related to Kirkbya (Glyptopleura?) venosa but is distinguished by the more oblique and truncated ends, by the more strongly reticulating ridges, and apparently by the more distinct and differently shaped border.

Horizon and locality.-Batesville sandstone, Batesville quadrangle, Round Mountain (station 7089).

\section{CYTHERELLID $A$.}

\section{CYTHERELLA Jores.}

\section{Cytherella glandella Whitfield?}

1882. Oytherellina glandella. Whitfield, Am. Mus. Nat. Hist. Bull., vol. 1, p. 94, pl. 9, figs. 28, 29.

Warsaw limestone: Spergen Hill, Ind.

1883. Cytherellina glandella. Hall, Indiana Dept. Geol. and Nat. Hist. Twelfth Ann. Rept., for 1882, pl. 32, figs. 28, 29.

[St. Louis group: Spergen Hill, Ind.]

1906. Oytherellina glandella. Indiana Dept. Geol. and Nat. Res. Thirtieth Ann. Rept., for 1905, pl. 26, figs. 28, 29.

[Salem limestone: Spergen Hill, Ind.]

A single specimen is included here, a very transverse, regularly elliptical shell having a width of 0.8 millimeter and a height of 
0.4 millimeter. The upper and lower margins are nearly straight and parallel and the ends broadly and regularly rounded. A slightly marked border or flange seems to be present. Otherwise the convexity is regular and moderately strong.

This specimen very much resembles Cytherellina glandella of the Spergen limestone. It does not, however, show the faint sulcus and mdistinct tubercle described by Whitfield, and it does show a slight tendency to flare at the margin, a feature not mentioned by him. Whitfield fails to give the dimensions of $C$. glandella, so that a comparison in this particular is not possible.

Horizon and locality.-Batesville sandstone, Batesville quadrangle, Round Mountain (station 7089). 


\section{REGISTER OF LOCALITIES.}

1234A4. Batesville quadrangle. Bluffs of White River at Ramsey Ferry, about $1 \frac{1}{4}$ miles southeast of Batesville, Ark. Here are combined collections made at different times by Stuart Weller, E. O. Ulrich and G. I. Adams, and G. H. Girty. Not all the material was found in place.

1247A. Marshall quadrangle. Sandstone quarry one-half mile east of Marshall, Ark.

J. C. Branner, July, 1889.

1248B. Batesville quadrangle. Batesville sandstone beyond Spring Creek.

H. S. Williams.

1248D. Batesville quadrangle. One and one-half miles west of Batesville, Ark., on road to Ruddell's mill on Spring Creek. From lower 20 feet of the Batesville sandstone.

E. O. Ulrich and G. I. Adams, September 8, 1902 . Collections of loose material from about the same locality made by Stuart Weller in 1891 and G. H. Girty in 1907 are also included.

7039a. Marshall quadrangle. Batesville sandstone in bank of stream, one-half mile northeast of Marshall, Ark.

G. H. Girty, September 17, 1907.

7089. Batesville quadrangle. Round Mountain, 10 miles west of Batesville, Ark. Calcareous layers in the upper part of the Batesville sandstone.

G. H. Girty, September 4, 1907.

7090. Marshall quadrangle. Along road one-fourth mile west of Marshall, Ark.

G. H. Girty; September 18, 1907.

7091. Marshall quadrangle. Calcareous material associated with Batesville sandstone; loose in a field $1 \frac{1}{2}$ miles southeast of Marshall, Ark.

G. H. Girty, September 19, 1907.

7092. Marshall quadrangle. Roadside, one-half mile northeast of Marshall, Ark. From limestone just above or in the upper part of the Batesville sandstone.

G. H. Girty, September 17, 1907.

7092a. Marshall quadrangle. Roadside, 1 mile east of Marshall, Ark., from nodular limestone in soft beds near the top of the Batesville sandstone.

G. H. Girty, October 11, 1908.

7093. Marshall quadrangle. Near road on the MacDaniel farm, at the southeast end of Granny Mountain. At the base of the Batesville sandstone.

G. H. Girty, October 10, 1908.

7093a. Marshall quadrangle. Along road, perhaps one-eighth mile south of locality 7093. Batesville sandstone.

G. H. Girty, October 10, 1908.

7093b. Marshall quadrangle. Along road, about $1 \frac{1}{2}$ miles northeast of locality 7093. Batesville sandstone.

G. H. Girty, October 10, 1908.

7587. Marshall quadrangle. Sandstone in the town of Marshall, Ariz.

E. O. Ulrich and G. I. Adams.

7699. Batesville quadrangle. Batesville, Ark. Loose pieces of Batesville sandstone on hillside by main road on the northeast edge of town.

G. H. Girty, July 5, 1911.

7700. Batesville quadrangle. Loose blocks of Batesville sandstone, 1 mile north of Sharps Crossroads.

G. H. Girty, July 5, 1911. 


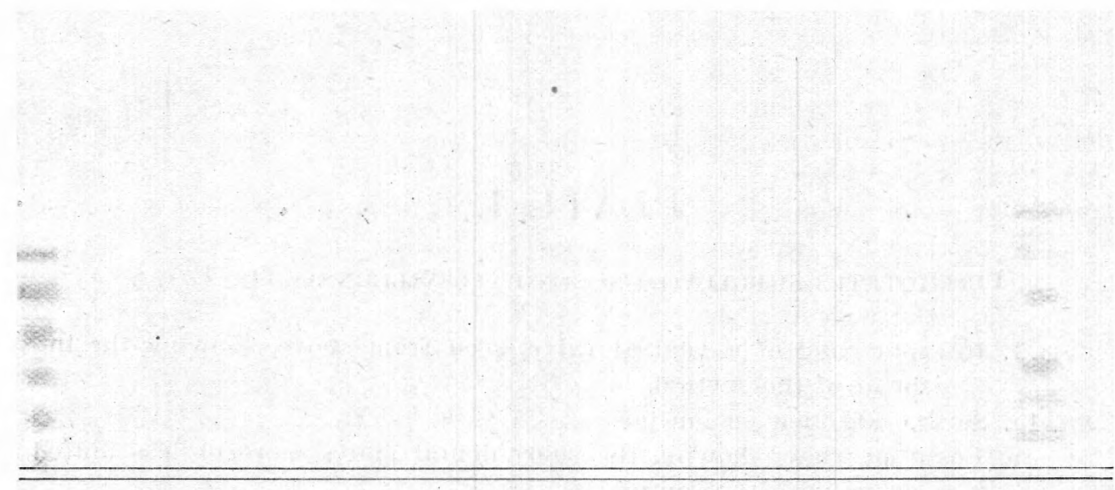

PLATE I. 


\section{PLATE I.}

Orthotetes SubgLobosus var. Batesvillensis (p. 42 ).

Figure 1. Internal mold of a ventral valve, seen from above, showing the imprint of the septum.

1a. Same, side view in outline.

1b. Posterior view, showing the short dental plates more or less united above with the septum.

Marshall, Ark. (station 7587).

2. Internal mold of a ventral valve, posterior view, showing the dental plates apparently discrete from the septum.

Batesville, Ark. (station 7699).

3. Internal mold of a dorsal valve, seen from above, showing the impression of the hinge plate. The shell is young and nearly flat. In shells that are large and convex the posterior portion is nearly vertical, and the impression of the hinge plate can not then be seen in a similar view.

Spring Creek, Ark. (station 1248D).

4. Posterior view of a convex dorsal valve, showing the cardinal process. Marshall, Ark. (station 7587).

5. Internal mold of a large dorsal valve, seen from above.

Marshall, Ark. (station 7039a).

OrTHOTETES SUBGLOBOSUS var. PROTENSUS (p. 44).

Figure 6. Internal mold of a ventral valve provisionally referred to this variety. The specimen, which is broken, shows the high and very oblique area and a remnant of the septum.

Marshall, Ark. (station 7090). 


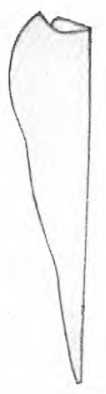

1a

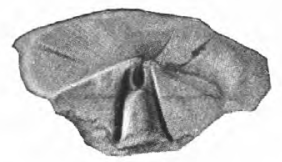

2

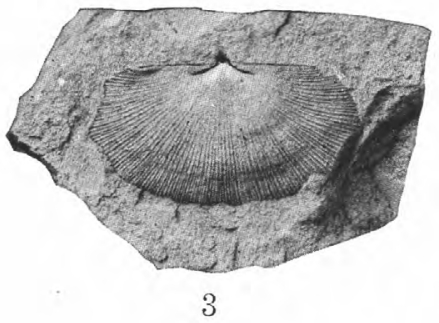

3

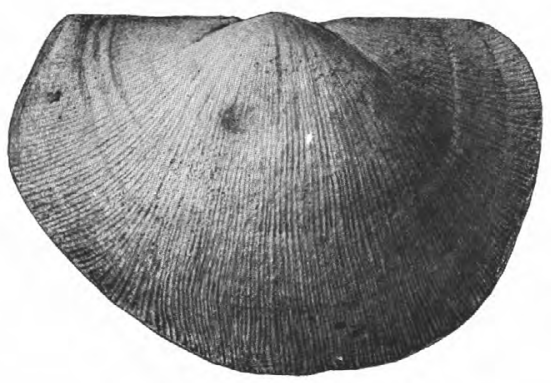

5
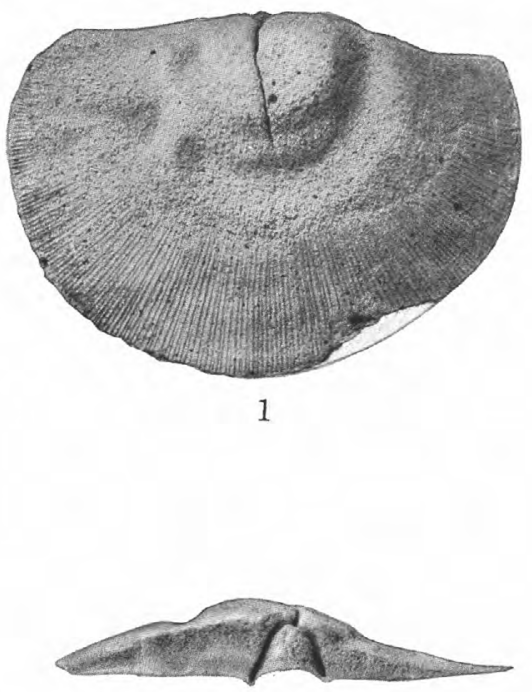

$1 \mathrm{~b}$
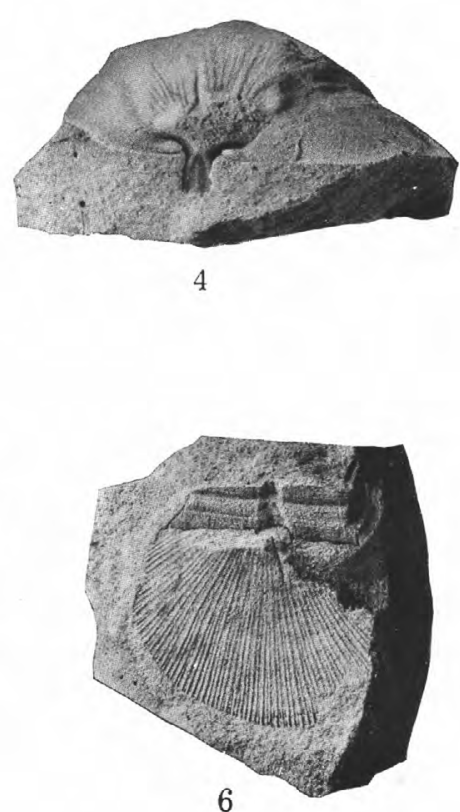

BRACHIOPODA. 



\section{PLATE II.}




\section{PLATE II.}

LiNgulidiscina batesvillensis (p. 39).

Figure 1. The type specimen, an internal mold.

1a. Same, side view in outline.

Batesville, Ark.

\section{SchUChertella williamsi (p. 40).}

Figure 2. The typical specimen, which, like that of the foregoing species, was loaned by the University of Chicago. The specimen is an internal mold and the figure shows the upper surface. The irregularity of the posterior outline is due less to breakage than to contortion.

2a. Same, side view in outline.

2b. Same, posterior view.

Batesville, Ark.

3. The only specimen found in the Survey collections. Seen from above.

3a. Same, side view in outline.

3b. View of the area. The complete absence of a septum is shown in this view and in figure 3.

Ramsey Ferry, Ark. (station 1234A4).

\section{Productella hirsutiformis (p. 45 ).}

Figure 4. The only specimen discovered, probably an internal mold of a dorsal valve.

Spring Creek, Ark. (station 1248D).

$$
\text { Productus arkansanus (p. 46). }
$$

Figure 5. External mold of a dorsal valve.

5a. Same, side view in outline.

6. Internal mold of a ventral valve. The nodose character of the ribs is not as striking in the drawing as in the original.

6a. Same, side view in outline. Marshall, Ark. (station 7587).

7. External mold of a dorsal valve. The surface of the shell was covered with small spines, which left tiny holes in the mold. These holes are too small to show in the drawing clearly.

Marshall, Ark. (station 7090). 
U. S. GEOLOGICAL SURVEY

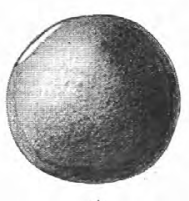

1

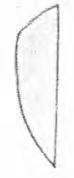

1a

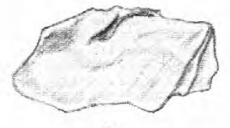

$3 a$

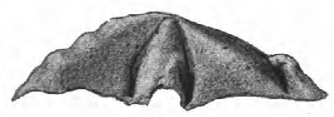

$3 \mathrm{~b}$

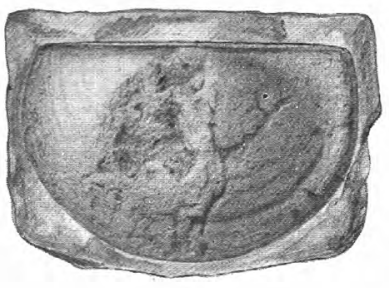

4

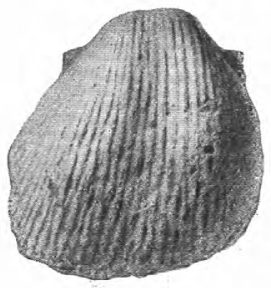

6

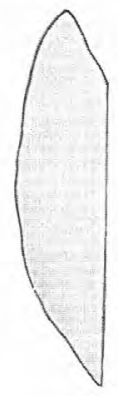

$2 a$

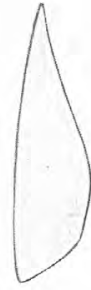

$5 a$

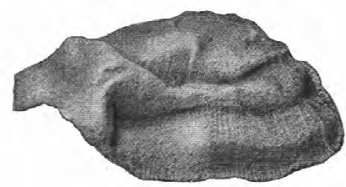

3
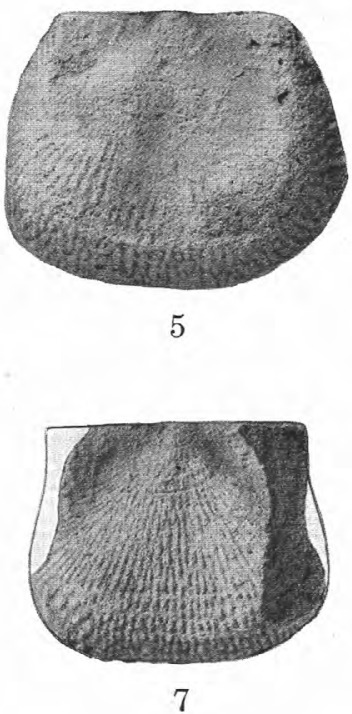

$6 a$

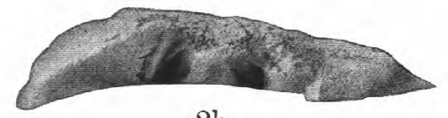

$2 \mathrm{~b}$

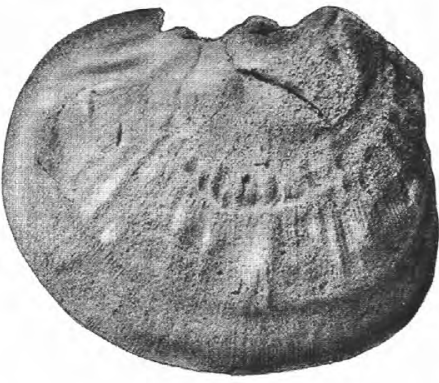

2

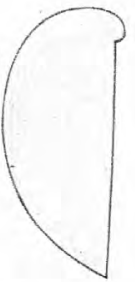

a.

BULLETIN 593 PLATE ॥

BRACHIOPODA. 



\section{PLATE III.}




\section{PLATE III.}

Diaphragmus fasciculatus (p. 56).

FIgURE 1. Mold in sandstône of the inside of a ventral valve, slightly deformed and slightly compressed.

1a. Side view in outline.

Marshall, Ark. (station 7587).

2. A testiferous specimen, rather more finely striated than the average.

2a. Side view in outline.

Granny Mountain, Ark. (station 7093a).

3. A testiferous specimen showing fasciculation of the costæ.

3a. Side view of same.

Marshall, Ark. (station 7092).

4. Mold of a dorsal valve, showing the impression of the outside of the visceral area and bordering it the broad band of the internal diaphragm.

Marshall, Ark. (station 7090).

\section{Diaphragmus elegans (p. 59).}

Figure 5. A small testiferous ventral valve, seen from above. The cincture seems to represent a thickened ring on the inside of the shell. which probably corresponds to the diaphragm of the other valve. 5a. Siale view in outline.

Round Mountain, Ark. (station 7089).

\section{Productus adairensis (p. 50).}

Figure 6. External mold of a dorsal valve.

Marshall, Ark. (station 7587).

Productus inflatus var. coloradoensis? (p. 47 ).

Figure 7. A testiferous ventral valve provisionally referred to this species (seen from above).

7a. Side view in outline.

7b. Posterior view.

Marshall, Ark. (station 7092a).

8. A dorsal valve referred to the same species (seen from above).

8a. Side view in outline.

Marshall, Ark. (station 7091). 
U. 8. GEOLOGICAL SURVEY

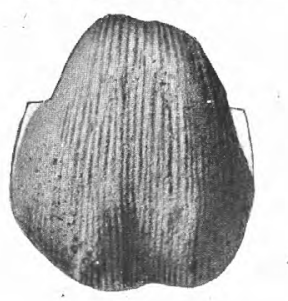

1

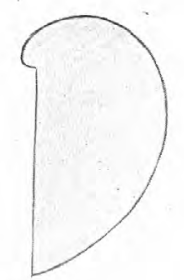

$2 \mathrm{a}$

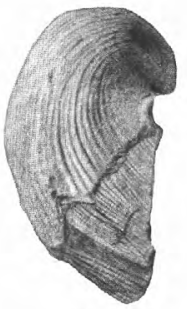

$3 a$

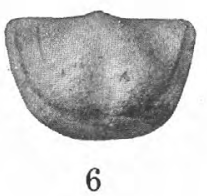

4
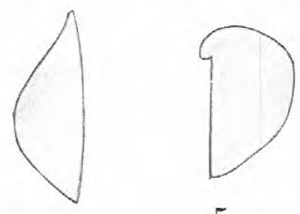

$5 \mathrm{a}$

$8 \mathrm{a}$

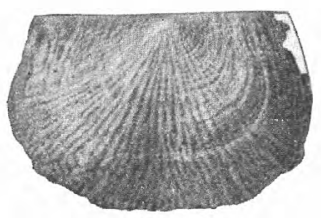

8
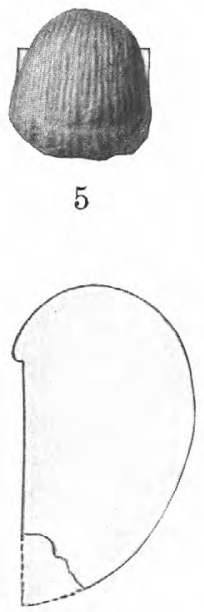

BULLETIN 593 PLATE III

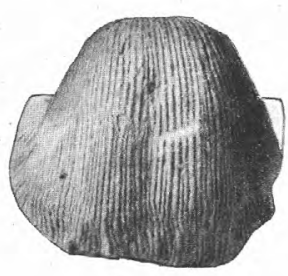

2
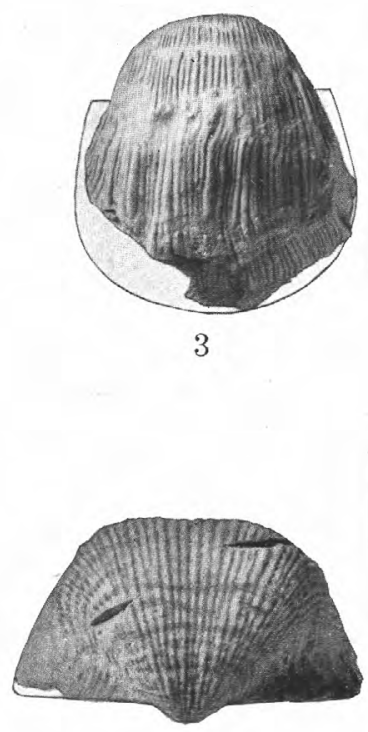

$7 \mathrm{~b}$

$7 a$

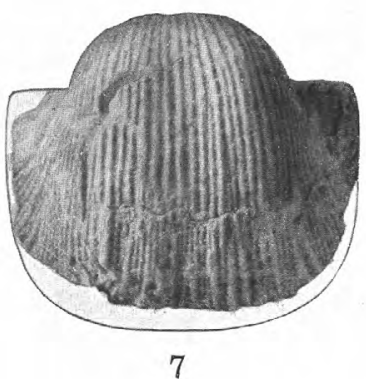

BRACHIOPODA. 

PLATE IV. 


\section{PLATE IV.}

Camarotechia purduei var. inflata (p. 60).

Figure 1. A specimen with three plications on the fold.

1a. Anterior view, $\times 2$.

1b. Side view in outline.

2. Another specimen similar to the last.

2a. Anterior view, $\times 2$.

2 b. Side view in outline.

3. A broad specimen with four plications on the fold.

3a. Anterior view, $\times 2$.

3b. Side view in outline.

3c. Ventral view.

4. A narrow specimen with four plications on the fold.

4a. Side view in outline.

Round Mountain, Ark. (station 7089).

Camarotechia purduei (p. 59).

Figure 5. Internal mold of a characteristic dorsal valve.

Spring Creek, Ark. (station 1248D).

Reticularia setigera? (p. 65).

Figure 6. Internal mold of a dorsal valve, obliquely compressed.

Ramsey Ferry, Ark. (station 1234A4).

SPIRIFER INCREBESCENS (p. 63).

Figure 7. Internal mold of a rather small ventral valve.

8. Internal mold of a rather large dorsal valve.

Spring Creek, Ark. (station 1248D).

\section{SPIRIFERINA SPINOSA? (p. 66).}

Figure 9. Internal mold of a dorsal valve.

Ramsey Ferry, Ark. (station 1234A4).

SPIRIFERINA TRANSVERSA (p. 68).

Frgure 10. Internal mold of a dorsal valve.

Ramsey Ferry, Ark. (station 1234A4).

Cliothyridina sublamellosa (p. 69).

Figure 11. Internal mold of a large dorsal valve.

Ramsey Ferry, Ark. (station 1234A4).

12. A small exfoliated ventral valve, $\times 2$.

Granny Mountain, Ark. (station 7093).

13. Internal mold of a ventral valve. This specimen suggests Athyris densa, but the shape has been modified by compression.

Ramsey Ferry, Ark. (station 1234A4). 


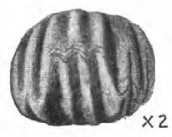

1a

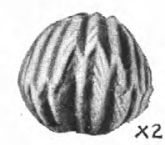

$2 a$

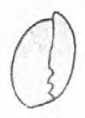

$3 \mathrm{~b}$

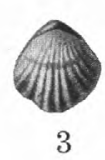

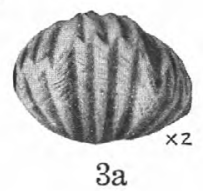

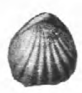

1

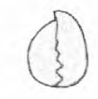

1b

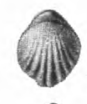

2

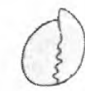

$2 \mathrm{~b}$

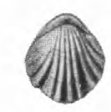

4

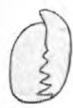

$4 a$

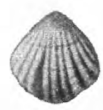

$3 \mathrm{c}$

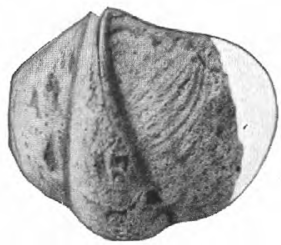

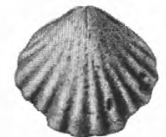

5

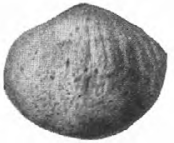

11

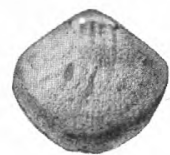

13

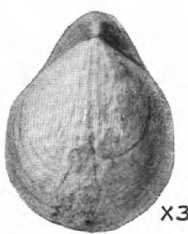

$17 \mathrm{a}$
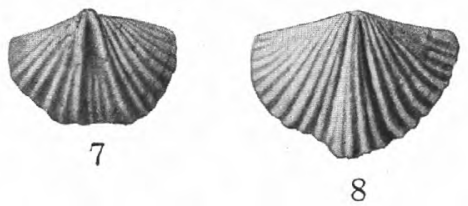

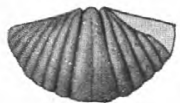

10

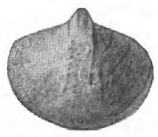

14

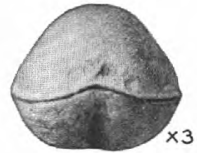

$17 d$

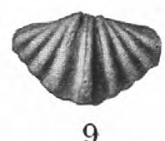

9

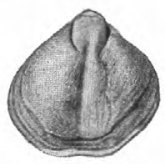

15

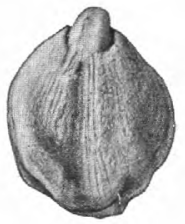

16

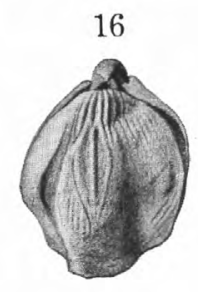

$16 a$

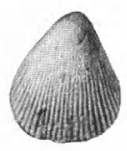

19

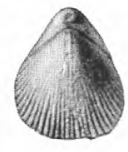

$19 a$

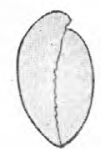

$19 \mathrm{~b}$ 

PLATE IV.

\section{Cliothyridina elegans (p. 72).}

Figure 14. Internal mold of a ventral valve.

Ramsey F'erry, Ark. (station 1234A4).

\section{Composita subquadrata (p. 72).}

Figure 15. Internal mold of a small ventral valve figured by Prof. Weller.

Ramsey Ferry, Ark. (station 1234A4).

16. Internal mold of a bivalved specimen, somewhat compressed. Ventral view.

16a. Dorsal view.

Marshall, Ark. (station 7090).

\section{Composita acinus (p. 74).}

Figure 17. Ventral view of a large specimen, $\times 3$.

17a. Dorsal view, $\times 3$.

17b. Same, natural size, in outline.

17c. Side view in outline.

17d. Anterior view, $\times 3$.

Round Mountain, Ark. (station 7089).

\section{EuMetria marcyi (p. 75).}

Figure 18. A large rotund specimen.

Granny Mountain, Ark. (station 7093).

19. Ventral view of a specimen closely similar to the type specimen.

19a. Dorsal view.

19b. Side view in outline.

Round Mountain, Ark. (station 7089). 



\section{PLATE V.}




\section{PLATE V.}

Dielasma formosem var. Whitfieldi (p. 61).

Figure 1. Dorsal view of the most characteristic specimen seen. The others from the same locality are all smaller (immature), whereas the sandstone specimens are larger but compressed and deformed.

1a. Anterior view in outline.

1b. Side view in outline.

Round Mountain, Ark. (station 7089).

Girtyella turgida var. elongata (p. 62).

Figure 2. Dorsal view of a characteristic specimen.

2a. Side view in outline.

2b. Ventral view.

2c. Anterior view.

3. A small specimen with strong plications.

3a. Anterior view.

Granny Mountain, Ark. (station 7093).

Goniatites choctawensis (p. 129).

Figure 4. Side view of the most complete specimen obtained. It is preserved as a mold in sandstone.

5. Suture taken from another specimen similarly preserved. The sutures are not clearly shown throughout and the drawing may consequently be incorrect in some of its details.

Spring Creek, Ark. (station 1248D).

\section{Gastrioceras caneyandm (p. 131).}

Figure 6. A mold in sandstone. In removing the rock from the umbilicus that structure may have been made to appear too large.

6a. Ventral view showing aperture.

Ramsey Ferry, Ark. (station 1234A4).

Orthoceras indianum (p. 126).

Figure 7. Side view of a specimen which is almost completely exfoliated, $\times 2$.

7a. Part of the surface, $\times 5$.

Round Mountain, Ark. (station 7089).

ORTHOCERAS aff. EUREKENSE (p. 128).

Figure 8. The only specimen observed, the one previously figured by Prof. Weller.

Spring Creek, Ark. (station 1248D).

Orthoceras caneyandm? (p. 126).

FIGURE 9. Side view of a specimen showing great irregularity in the length of the chambers.

9a. Same, $\times 2$.

Round Mountain, Ark. (station 7089).

Solenocheilus? sp. (p. 129).

Figure 10. A very fragmentary specimen, the only one found.

Round Mountain, Ark. (station 7089). 
U. S. GEOLOGICAL SURVEY
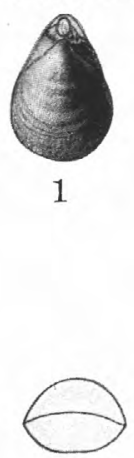

1a

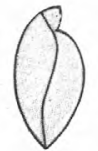

$1 \mathrm{~b}$

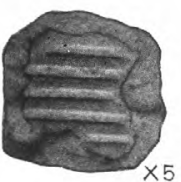

$7 \mathrm{a}$
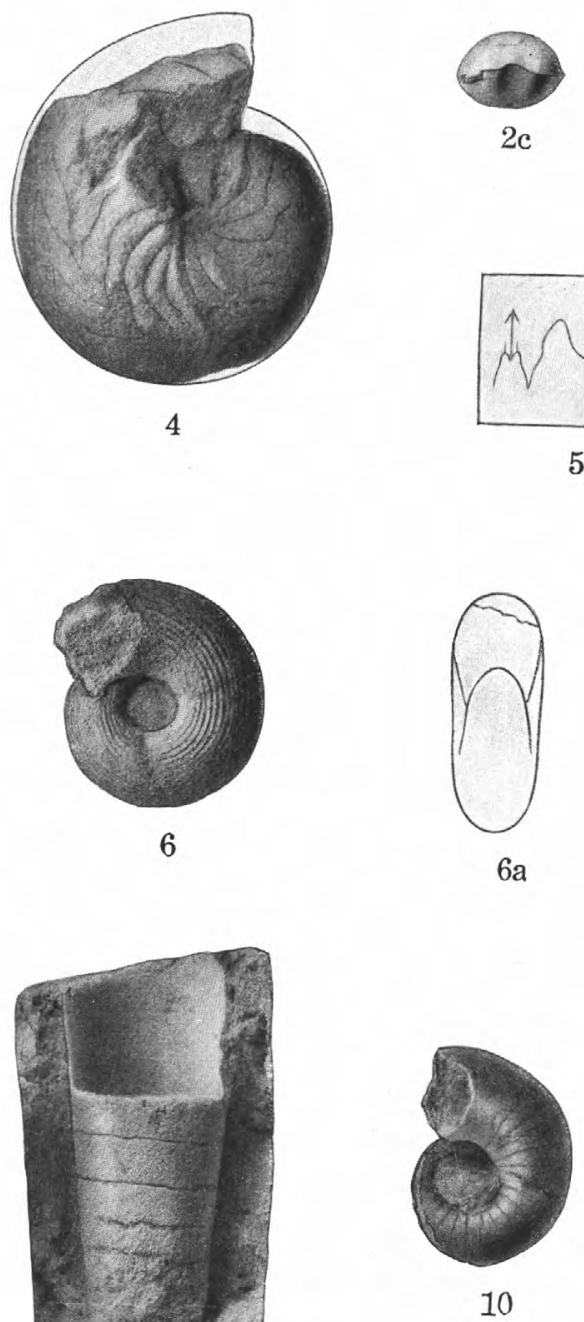

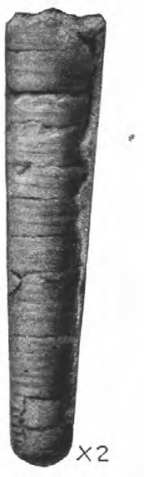

7
8

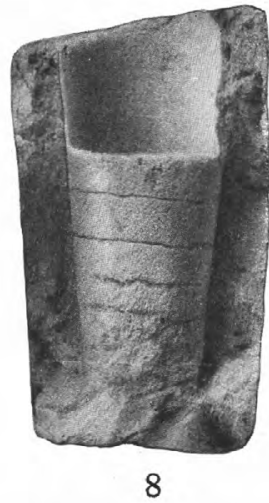

BRACHIOPODA AND CEPHALOPODA.

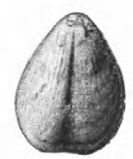

$2 b$
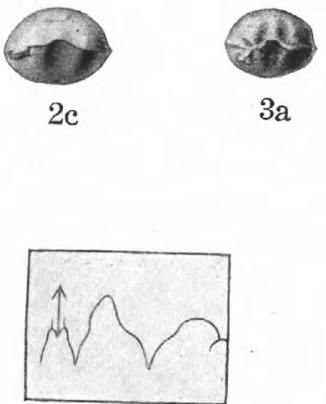

5

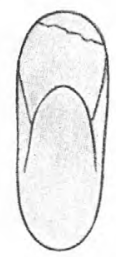

$6 a$

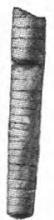

9

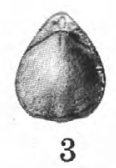

$3 a$ 

PLATE VI. 


\section{PLATE VI.}

\section{Mralina welleriana (p. 93).}

Figure 1. A large left valve.

2. A small left valve.

Marshall, Ark. (station 7587).

Myalina inlinoisensis var. (p. 95).

Figure 3. A left valve.

Ramsey Ferry, Ark. (station 1234A4).

Myalina illinoisensis (p. 94).

Figure 4. A large left valve somewhat distorted by pressure.

5. A normal left valve.

Ramsey Ferry, Ark. (station 1234A4).

Myalina monroensis (p. 96).

FIGURE 6. Right valve of a characteristic specimen of the type referred to this species.

6a. Left valve of same specimen.

Ramsey Ferry, Ark. (station 1234A4).

Myalina elongata (p. 97).

Figure 7. A typical specimen with spreading anterior side and conspicuous lobe.

Marshall, Ark. (station 7587).

8. A specimen with nearly vertical anterior side and less conspicuous lobe.

Spring Creek, Ark. (station 1248D).

Lithophagus batesvillensis (p. 107).

Figure 9. A small well-preserved right valve.

Marshall, Ark. (station 7091).

10. A large right valve preserved as a mold in sandstone.

Ramsey Ferry, Ark. (station 1234A'4).

\section{Mroconcha? DUbIa (p. 106).}

Figure 11. A right valve, the only specimen found, $\times 2$.

Round Mountain, Ark. (station 7089).

Deltopecten batesvillensis (p. 103).

Figure 12. A small right valve.

13. A left valve.

Spring Creek, Ark. (station 1248D).

14. A well-preserved left valve.

14a. Same, $\times 2$.

Sharps Crossroads, Ark. (station 7700).

15. Another left valve.

Spring Creek, Ark. (station 1248D).

Deltopecten sp. $a$ (p. 105).

Figure 16. Squeeze of a right valve.

Marshall, Ark. (station 7587). 
U. S. GEOLOGICAL SURVEY

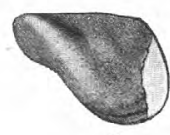

3

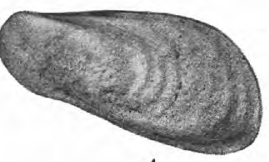

4

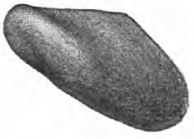

5

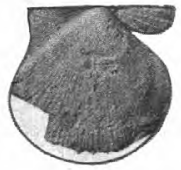

12

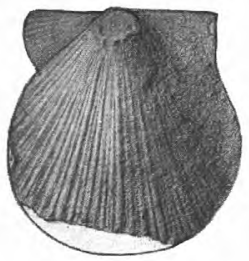

13

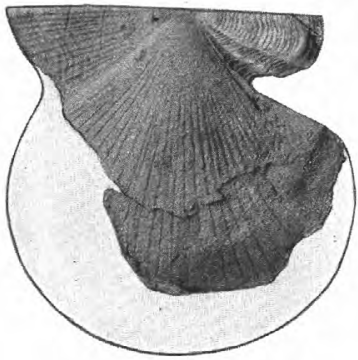

16

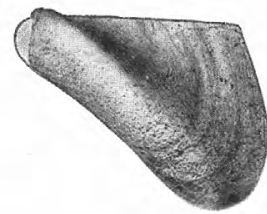

2

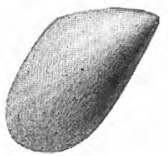

6

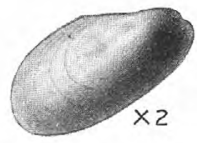

11

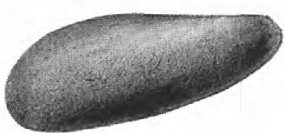

10

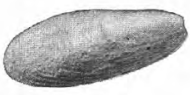

9

$6 \mathrm{a}$

BULLETIN 593 PLATE VI
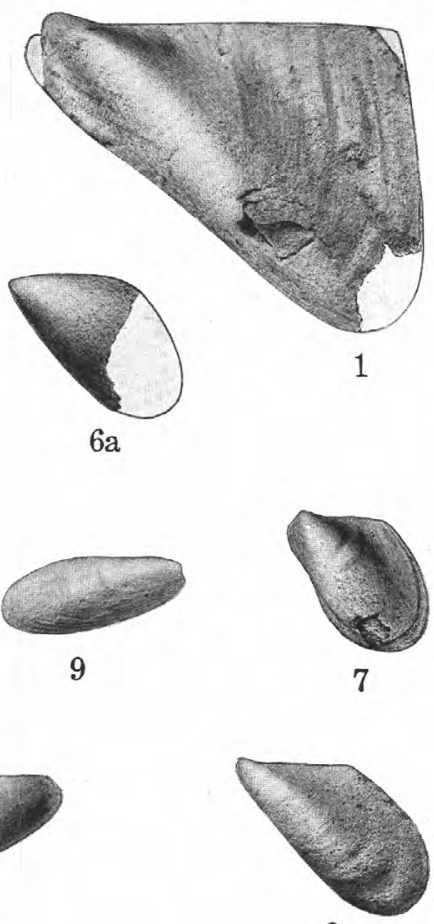

8
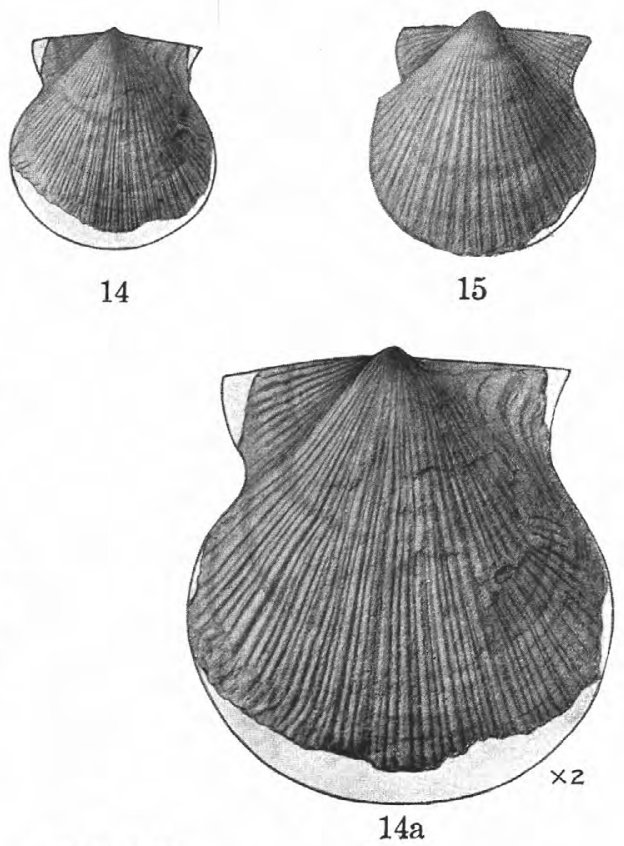

PELECYPODA. 



\section{PLATE VII.}




\section{PLATE VII.}

Sulcatipinna arkansana (p. 87).

Figure 1. Internal mold of an imperfect right valve.

Marshall, Ark. (station 7587).

Leptodesma SPERgenense var. RoBUstum (p. 89).

Figure 2. A bivalved specimen, more or less imperfect. Right valve.

2a. Left valve.

Ramsey Ferry, Ark. (station 1234A4).

3. A somewhat imperfect left valve.

Spring Creek, Ark. (station 1248D).

Leptodesma CARBoniferęu (p. 88).

Figure 4. A large left valve.

5. An imperfect right valve.

6. A left valve.

Marshall, Ark. (station 7587).

Conocardium cuneatum? (p. 90).

Figure 7. A left valve, perhaps somewhat deformed by compression.

7a. Same in outline, natural size.

Batesville, Ark. (station 7699).

\section{CaNeyelua hopkinsi (p. 91).}

Figure 8. A left valve, apparently without costæ. This is the type which Prof. Weller called Pteronites lavis.

9. A left valve, showing traces of costæ.

Marshall, Ark. (station 7587).

10. A bivalved specimen with rather strong costæ. Right valve. 10a. Left valve.

11. A left valve from Batesville with traces of costæ. As shown in the drawing this specimen has a faint sinus in the outline of the wing.

Ramsey Ferry, Ark. (station 1234A4). 


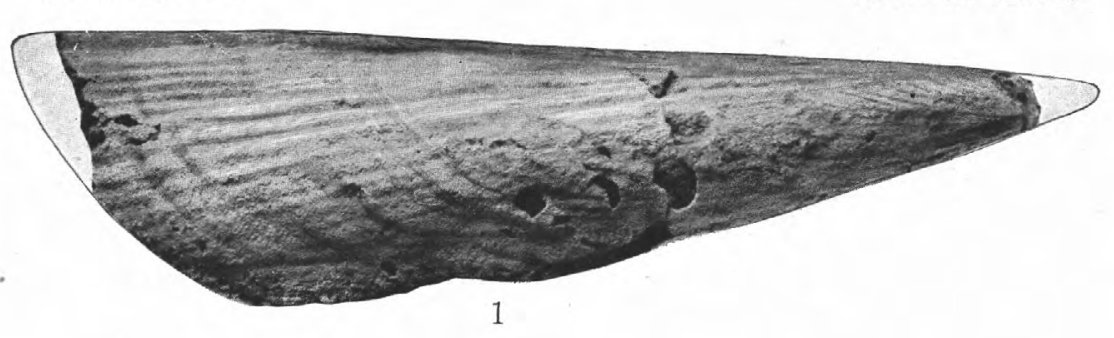

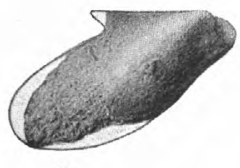

2

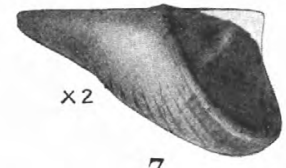

7

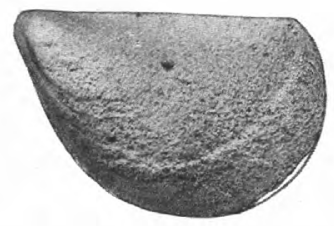

8
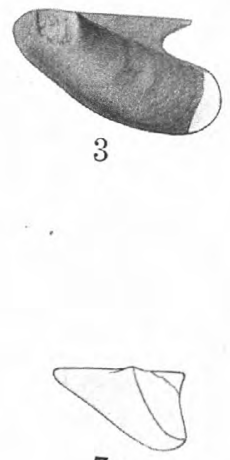

$7 \mathrm{a}$

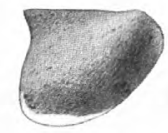

5

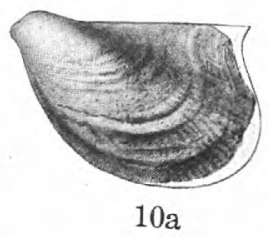

PELECYPODA.

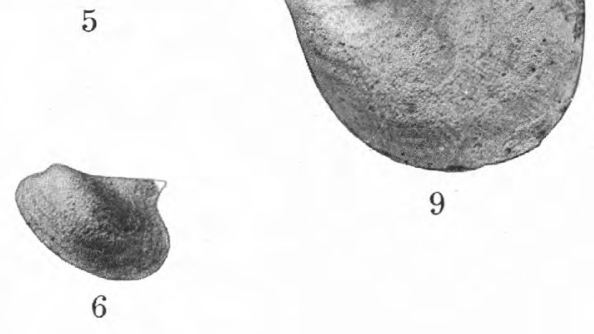

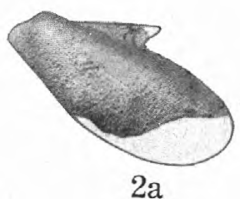

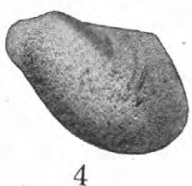

9

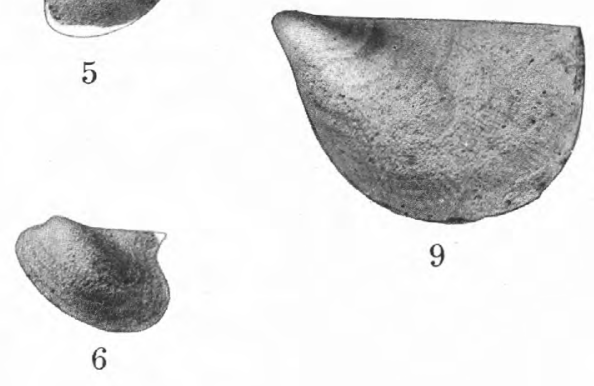

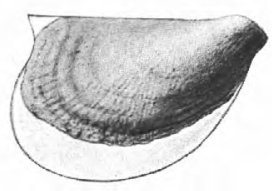

10
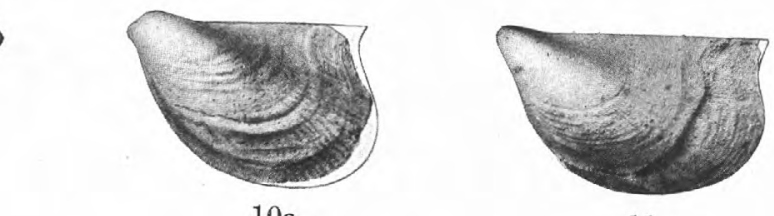

11 

PLATE VIII. 


\section{PLATE VIII. \\ Aptychus solidum (p. 132).}

Figure 1. Side view of the only specimen found.

1a. Same, $\times 2$.

Round Mountain, Ark. (station 7089).

Sphenotus constrictus (p. 80).

Figure 2. A right valve preserved as a mold in sandstone.

Marshall, Ark. (station 7587).

Sphenotus cultellus (p. 79).

Figure 3. A right valve preserved as a mold in sandstone.

Marshall, Ark. (station 7587).

Sphenotus washingtonensis (p. 77 ).

Figure 4. Internal mold of a left valve referred to this species.

Granny Mountain, Ark. (station 7093a).

\section{Sphenotus vulgaris ( $p .78$ ).}

Figure 5. A characteristic right valve.

Ramsey Ferry, Ark. (station 1234A4).

6. A small left valve. All these specimens are considerably smaller than the largest examples referred to the species.

Spring Creek, Ark. (station 1248D).

7. Another right valve, smaller than the one shown in figure 5, with higher convexity and more distinct umbonal ridge.

Ramsey Ferry, Ark. (station 1234A4).

SpHenotus aff. meslariands (p. 80).

Figure 8. An imperfect left valve, chiefly preserved as an internal mold.

Round Mountain, Ark. (station 7089).

\section{Edmondia equilateralis (p. 81).}

FIgURE 9. An imperfect right valve agreeing very closely with this species. Natural size in outline.

9a. Same, $\times 2$.

Marshall, Ark. (station 7091). 
U. S. GEOLOGICAL SURVEY

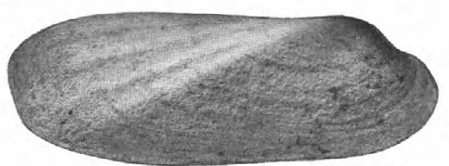

2

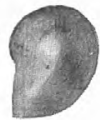

1
BULLETIN 593 PLATE VIII

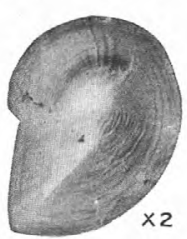

$1 \mathrm{a}$

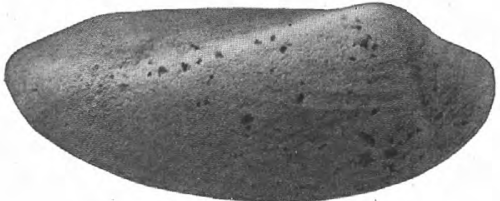

3

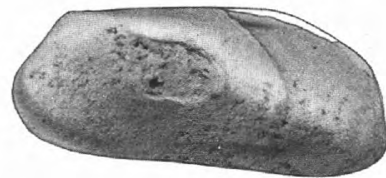

4

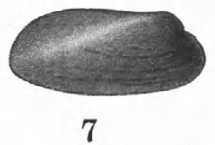

6

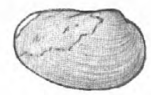

9
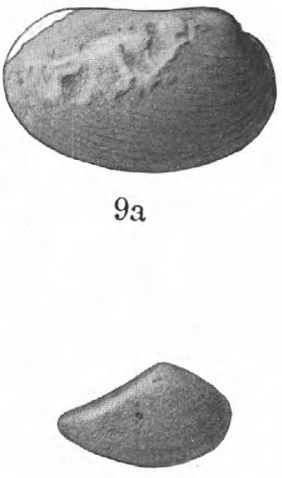

16

10

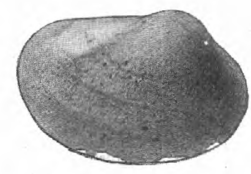

11

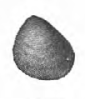

13

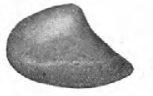

14

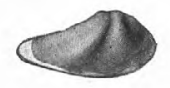

15

PELECYPODA AND CEPHALOPODA?. 

EdMONDI CRASSA var. SYMMETRICA (p. 82).

Figure 10. A right valve referred to this variety.

Ramsey Ferry, Ark. (station 1234A4).

Edmondia CRassa (p. 82).

Figure 11. An imperfect right valve referred to this species.

Spring Creek, Ark. (station 1248D).

Nucula rectangula (p. 83).

Figure 12. Left valve of a specimen preserved as an internal mold.

12a. Cardinal view in outline.

Granny Mountain, Ark. (station 7093a).

Nucula shumardiana (p. 84).

Figure 13. Internal mold of a left valve.

Spring Creek, Ark. (station 1248D).

LEDA NUCULIFORMis? (p. 86).

Figure 14. A left valve provisionally referred here.

Granny Mountain, Ark. (station 7093a).

\section{LEDA PANDORIFORMIS? (p. 84).}

Figure 15. Right valve of a small specimen provisionally referred to this species.

Round Mountain, Ark. (station 7089).

16. A right valve preserved as a mold in sandstone, of a form apparently intermediate in shape between the other specimen referred to L. pandoriformis and that referred to $L$. nuculiformis.

Ramsey Ferry, Ark. (station 1234A4). 



\section{PLATE IX.}




\section{PLATE IX.}

\section{Schizodus batesvillensis (p. 97).}

Frgure 1. A large left valve.

2. A smaller left valve of somewhat different shape.

Marshall, Ark. (station 7587).

\section{Schizodus arkansanus (p. 101).}

Figure 3. A small left valve.

Spring Creek, Ark. (station 1248D).

4. A nearly perfect right valve.

Ramsey Ferry, Ark. (station 1234D).

Schizodus branneriands (p. 100).

Figure 5. A specimen retaining both valves. The right valve.

5a. Left valve of same specimen.

Granny Mountain, Ark. (station 7093).

Schizodus depressus var. CIRCUlus (p. 100).

Figure 6. A right valve referred to this variety.

Spring Creek, Ark. (station 1248D).

\section{Schizodos dePREssus? (p. 98).}

FIgURE 7. A right valve doubtfully identified (compare with figs. 13, 13a).

Spring Creek, Ark. (station 1248D).

Schizodus dePREssus var. ABRUPTUs (p. 99).

Figure 8. A mold in sandstone of a right valve.

Marshall, Ark. (station 7587).

9. Another right valve similarly preserved.

Spring Creek, Ark. (station 1248D).

10. A transverse type which approaches $S$. chesterensis in outline.

11. A small right valve resembling the foregoing, $\times 2$.

11a. Same, in outline, natural size.

12. An imperfect right valve in limestone, $\times 2$.

12a. Same, in outline, natural size.

Round Mountain (station 7089).

\section{Schizodus Depressus (p. 98).}

Figure 13. The type specimen loaned by the Illinois State Museum of Natural

History. It has been somewhat uncovered, and the shape somewhat changed from the original illustration in consequence.

13a. Same, $\times 2$.

St. Louis limestone, Monroe County, Ill. 

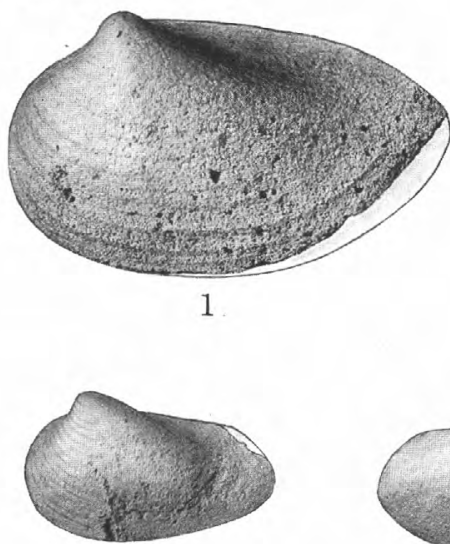

3

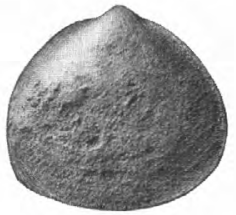

6

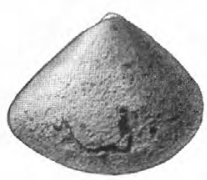

8

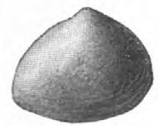

13

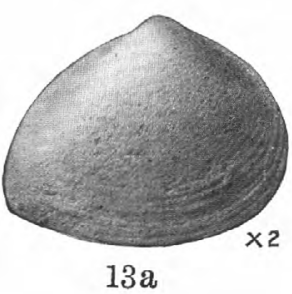

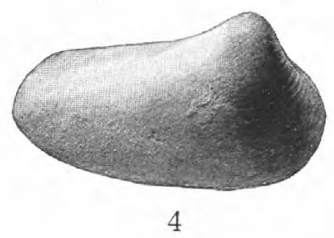

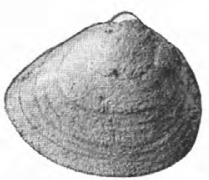

7
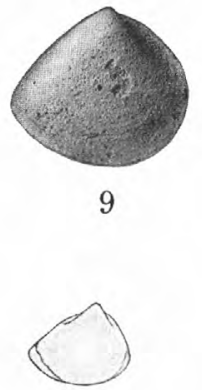

$11 a$

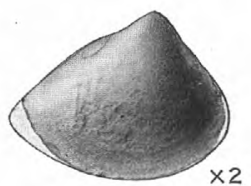

11
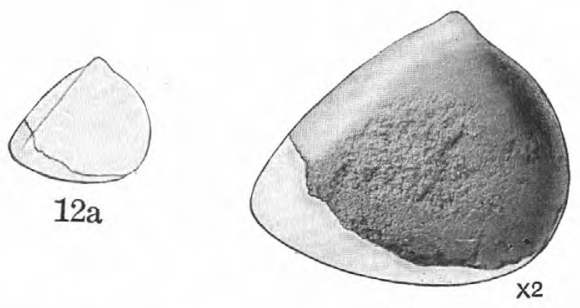

12

PELECYPODA 



\section{PLATE X.}




\section{PLATE X.}

Allerisma walkeri (p. 108).

F'IGURE 1. Onc of the type specimens.

2. Another type, which, like the preceding, was loaned by Walker Museum of Chicago University. This specimen shows an obscure fold on the postumbonal slope.

Batesville, Ark.

Allerisma walkeri var. (p. 109).

Figure 3. A right valve.

Spring Creek, Ark. (station 1248D).

Allerisma maxvillense (p. 108).

Figure 4. A right valve rather more robust and less transverse than that shown by figure 5 .

5. Right valve of an imperfect specimen resembling the type.

Granny Mountain, Ark. (station 7093).

\section{Allerisma neglectum (p. 109).}

Figure 6. A characteristic right valve.

7. A left valve.

8. A right valve of somewhat different shape.

Spring Creek, Ark. (station 1248D).

Cypricakdella oblonga (p. 110).

Figure 9. A left valve preserved as a mold.

10. A right valve similarly preserved.

Granny Mountain, Ark. (station 7093a).

Endothyra discoidea (p. 27).

FIgURE 11. Section through the axis, $\times 100$.

12. Another similar section, $\times 100$.

13. A section in the plane of revolution, $\times \mathbf{1 0 0}$.

14. Another section similarly oriented, $\times 100$.

15. Another similar section, $\times \mathbf{1 0 0}$.

16. Another similar section, $\times 100$.

Round Mountain, Ark. (station 7089).

Trochammina sp. (p. 26).

Figure 17. A section, $\times 100$.

18. Another section, $\times 100$

Round Mountain, Ark. (station 7089). 


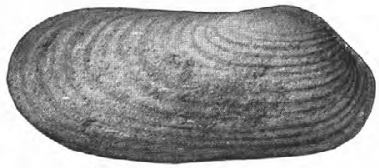

1

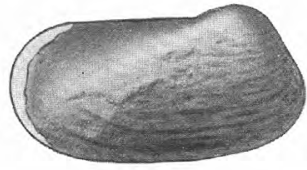

4

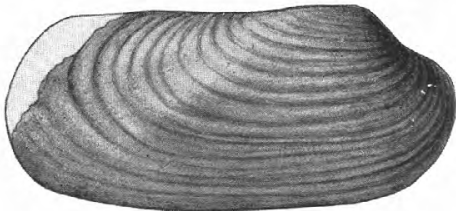

2

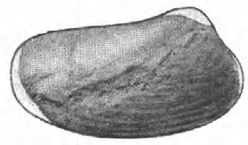

5

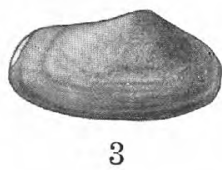

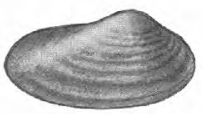

6

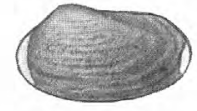

7

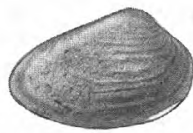

8

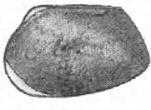

9

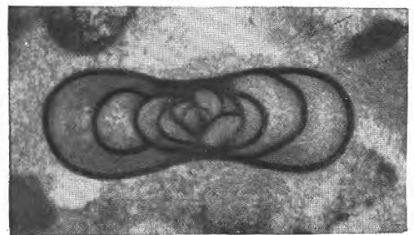

11

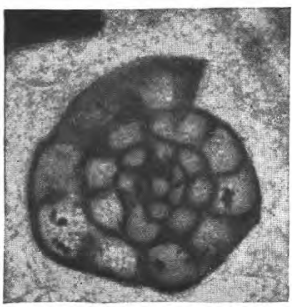

13
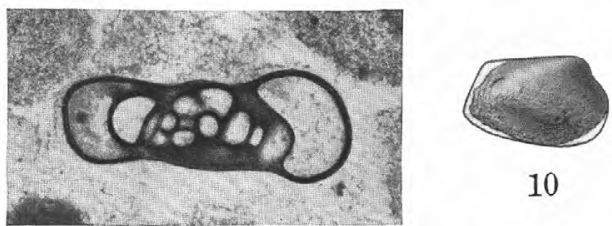

12

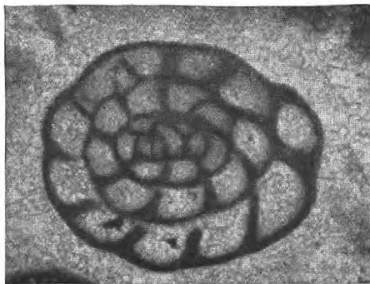

14

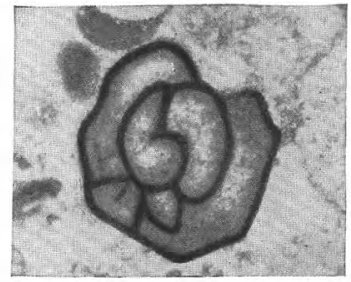

17

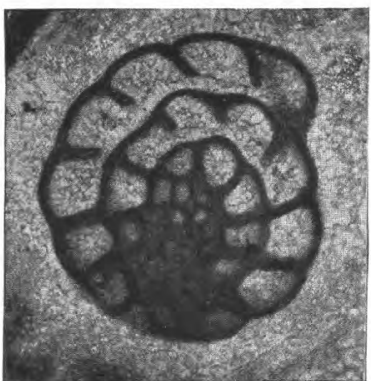

15

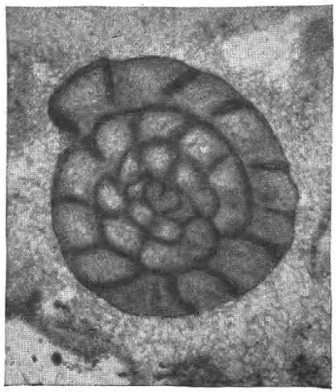

16

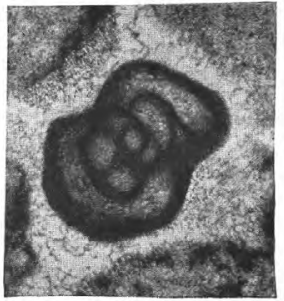

18

PELECYPODA AND FORAMINIFERA. 

PLATE XI. 


\section{PLATE XI.}

Rhopalonaria? sp. (p. 38).

Figure 1. Part of the cavity left by a shell in a mold in sandstone. The tubelike bodies which are now free represent perforations in the mass of the shell substance, $\times 5$.

Batesville, Ark. (station 7699).

$$
\text { Paraparchites nicklesi (p. 134). }
$$

Figure 2. A bivalved specimen, $\times 10$.

Marshall, Ark. (station 7091).

\section{Glyptopleura rhomboidalis (p. 136).}

Figure 3. A left valve, $\times 30$.

Round Mountain, Ark. (station 7089).

\section{Euomphalus similis (p. 120).}

Figure 4. The best-preserved specimen seen, $\times 2$.

Granny Mountain, Ark. (station 7093a).

\section{Bellerophon sp. (p. 117).}

Figure 5. Dorsal view of a rather large specimen preserved as an internal mold, $\times 3$.

5a. Side view in outline, natural size.

5 b. Same, $\times 3$.

Round Mountain, Ark. (station 7089).

\section{Patellostidm branneri (p. 118).}

Figure 6. A squeeze of the type specimen.

Batesville, Ark.

Pleurotomaria aff. perhumerosa (p. 113).

Figure 7. Side view of an internal mold, which is the only specimen seen, $X 2$.

7a. Same, seen from above, $\times 2$.

Round Mountain, Ark. (station 7089).

Pleurotomaria arkansana (p. 113).

Figure 8. Side view of the largest specimen seen, $\times 4$.

8a. Same in outline, natural size.

Granny Mountain, Ark. (station 7093). 
U. S. GEOLOGICAL SURVEY

BULLETIN 593 PLATE XI

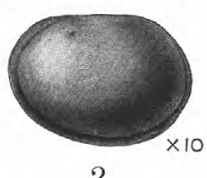

2

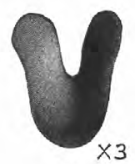

5

(Q) $5 \mathrm{a}$

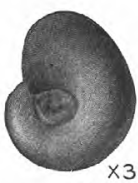

$5 \mathrm{~b}$

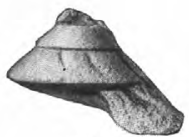

10

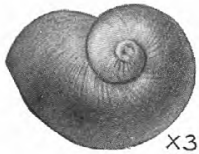

11
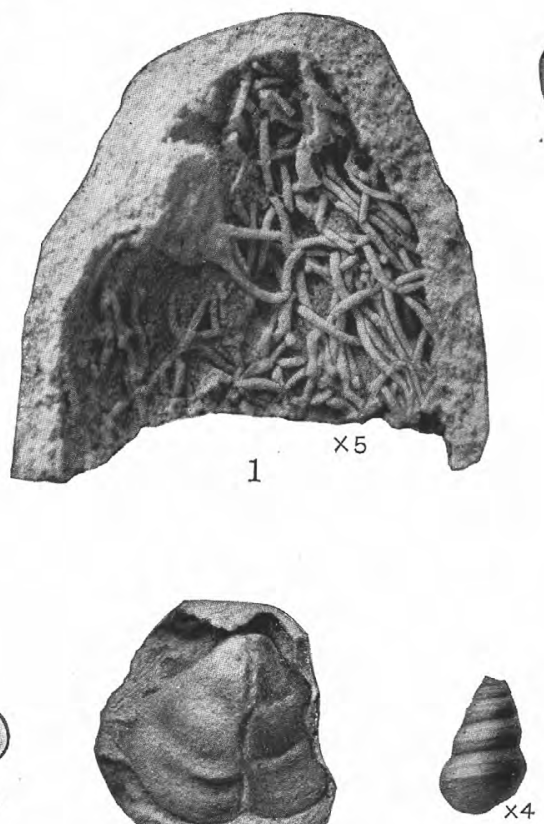

8

目

$8 a$

9

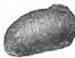

11b

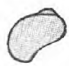

$12 \mathrm{a}$

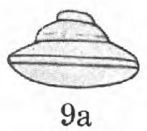

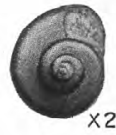

$7 \mathrm{a}$
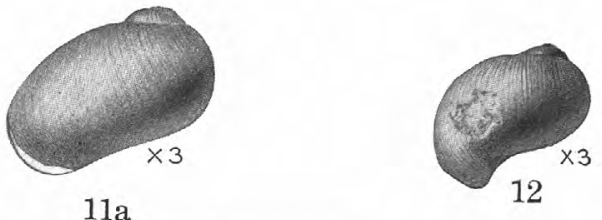

OSTRACODA, PORIFERA?, AND GASTROPODA. 



\section{Bembexia sp. (p. 115).}

Figure 9. Mold in sandstone of a small specimen, side view, $\times 2$.

9a. Same in outline, natural size.

Ramsey Ferry, Ark. (station 1234A4).

\section{Euconospira disjuncta (p. 114).}

FigURe 10. A specimen preserved as a mold in sandstone.

Ramsey Ferry, Ark. (station 1234A4).

\section{STROPHOSTYLUS SPLENDENS (p. 125).}

Figure 11. The typical specimen seen from above, $\times 3$.

11a. Side view opposite aperture, $\times 3$.

11b. Same, natural size.

12. Side view of another specimen, possibly somewhat broken at the aperture, $\times 3$.

12a. Same in outline, natural size.

Marshall, Ark. (station 7091).

Strophostylus aff. carleyands (p. 124).

Figure 13. The most perfect of the specimens included under this title (seen from above, $\times 3$.

13a. Side view, $\times 3$.

Marshall, Ark. (station 7091). 



\section{INDEX.}

A.

Adelphoceras meslerianum.

Allerisma arkansanum.

clavatum

consanguinatum...................... 110

maxvillense..................... 108, 110, 162

neglectum...................... 109-110, 162

walkeri...................... 108-109, 110, 162

walkeri var........................ 109,162

Aptychus solidum................... 132-133, 156

Archimedes proutanus.................... 37-38

Athyridæ........................... 69-77

Athyris incrassata........................ 70

lamellosa.................................. 72

mira................................ 71

obmaxima............................ 71

parvirostris............................ 70

planosulcata ..................... $69,70,71$

roissyi ............................. 71

sublamellosa....................... $69,70,71$

subquadrata......................... 72,73

Aviculopecten batesvillensis ............... 103

B.

Bartlett's quarry, collection from........... 9

Batesville fauna, relation of, to other faunas. 5-21

Batesville quadrangle, table of species from.. 12-14

Batesville sandstone, correlation of. . . . ..... 17-25 description of........................ $7-9$

Batostomella parvula.................... 28-30

Batostomellidæ........................... 28-32

Beede, J. W., cited........................ 51

Bellerophon branneri..................... 118

cancellatus.......................... 119

crassus.................................. 117

galericulatus ...................... 118

nautiloides.......................... 118

nodocarinatus ....................... 117

sublevis .......................... 116-117

textilis............................ 119

sp............................ 117-118, 164

Bellerophontidæ...................... 116-120

Bembexia sp....................... 115-116, 164

Beyrichiidæ.......................... 135-136

Brachiopoda............................ 39-77

Bryozoa............................. 28-38

Bucanopsis cancellata................... $\quad 119$

textilis................................ 119

\section{C.}

Camarotœechia purduei.

$59-60,61,146$

purduei var. inflata................6 $60-61,146$

Caneyella hopkinsi................ 91-92, 93,154

Capulidæ.............................. 123-125

Capulus acutirostris.................... 123, 124

Cephalopoda......................... 126-133
Page.

incrassata............................ 70,71

obmaxima........................... 71

orbicularis............................. 70

planisulcata.......................... 70

prouti.............................. 70

roissyi ............................. 70,71

sublamellosa...................... 69-72, 146

Cliothyris roissyi..................... 69,71 sublamellosa.......................... 69

Colenterata............................. 27

Collections, source of........................ 6

Composita acinus........................ 74,146

madisonensis.......................... 74

subquadrata..................... $72-74,146$

subtilita ........................ $70,73,74$

trinuclea........................... 73

Conocardiidæ.......................... $90-91$

Conocardium carinatum................... 90-91 cuneatum...................... 90-91, 154

meekanum......................... 91

Crania sp................................. 40

Craniidæ................................... 40

Cycloceratidæ.......................... 128

Cypress sandstone, suggested correlation of,

with Batesville sandstone.... 17-19, 20

Cypricardella connata.................... 111 oblonga....................... 110-111, 162

Cystodictya sp.......................... 32

Cystodictyonidæ........................ 32-34

Cytherella glandella................... 136-137

Cytherellidæ......................... 136-137

Cytherellina glandella................... 136, 137

D.

Deltopecten batesvillensis..... 103-104, 105, 106, 152

batesvillensis var..................... 105

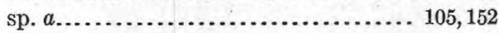

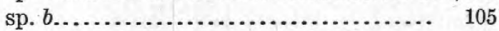

sp. c............................ 106

Dentaliidæ............................ 111-112

Dentalium venustum..................... 111

Diaphragmus.......................... $50-56$ abundant in Batesville area............ 16 elegans....................... 56, 57, 59, 144

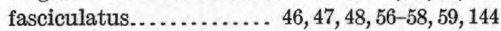

Dielasma formosum var. whitfieldi...... $61-62,150$ turgida var. elongata................... 62,63

Discinidæ.............................. $\quad 39$

E.

Edmondia crassa ....................... 82, 156 crassa var. symmetrica................. 82, 156 depressa............................. 82 equilateralis...................... 81, 156 nuptialis............................ 82 
Page.

Edmondia quadrata. strigillata. varsoviensis.

Endothyra baileyi....................... 27 discoidea........................ 27, 162

Euconospira disjuncta......... 114-115, 115, 116, 164 sp................................ 115

Eumetria marcyi..................... $75-77$ vera........................... $75,76,77$ var. costata...................... 76 verneuiliana.................... $75,76,77$ Euomphalidæ...................... 120-121 Euomphalus similis................ 120-121, 164 Euphemus sp

F.

Fenestella aff. serratula................. $35<36,37$ multispinosa .......................... 37 tenax............................ 34-35, 36

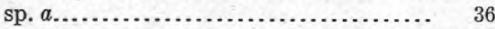

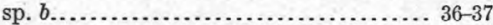

sp. c................................ 37

Fenestellidæ.......................... 34-38

Fayetteville shale, relations of, to Batesville sandstone.

G.

Gastrioceras caneyanum................ 131, 150 Gastropoda............................. 112-126 Girtyella turgida var. elongata..... 61,62-63, 150 Glyphioceras sphæricus.................. 129 Glyphioceratidæ....................... 129-133 Glyptopleura rhomboidalis ................ 136, 164

Glyptopora aff. plumosa................. 33,33-34 aff. punctipora....................... 32-33,34 aff. sagenella......................... 33 confined to Batesville area.............. $\quad 16$ elegans............................. 33 keyserlingi........................... 32,33

Goniatites choctawensis ............. 129-130,150 crenistria......................... 130 sphericus.............................. 130 striatus.............................. 129

Grammysiidæ....................... 81-82

Granny Mountain, collections near........ 11 Griffithides mucronatus................ 133-134

\section{H.}

Hall, James, and Clarke, J. M., cited........ 55 Harttina brevilobata var. marginalis......... 62, 63 Helmintha............................ 28

\section{K.}

Kirkbya (Glyptopleura) venosa

\section{L.}

Lævidentalium venustum. $111-112$

Leda bellistriata.

curta.

diversa.

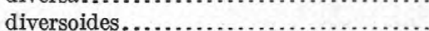

nasuta.

nuculiformis

ohioensis.
Leda pandoriformis................... 84-85, 156 vaseyana.......................... 85 (Yoldia) levistriata.................... 87

Ledidæ............................. 84-87

Leperditia nicklesi........................ 134

Leperditiidæ........................... 134-135

Lepetopsis levettei..................... 112

Leptodesma carboniferum......... 88-89, 106,154 (Liopteria) halli.................... 88-89 ortoni........................... 89 spergenense var. robustum..... 88, 89-90, 93,154 torreyi........................... 89

Lingulidiscina batesvillensis............... 39, 142 newberryi......................... 39

Lioclema sp ............................ 30

Lithophagus batesvillensis.......... 93,107, 152 pertenuis........................... 107

Lituolidæ........................................ 26

Localities, register of ....................... 138

Loxonema sp....................... 125-126

M.

McChesney, J. H., cited................... 58

Marginifera............................ 50-56

muricata......................... 51,54 splendens...................... 51,52-53,55

wabashensis......................... 51

Marshall, collections near................. 10-11

Marshall quadrangle, table of species from... 12-14

Microdon (Cypricardella) oblonga ........... 110

Modiola illinoisensis..................... 94, 95

Modiolopsidæ.......................... 106

Moorefield shale, differences between fauna of, and that of Batesville sandstone. $\quad 16$ difficulty of correlating . ................ 23-24 wedging out of.......................... 6

Myalina............................... $92-93$ arkansana.................. 90,92,94,95, 97 elongata......................... 96,97,152 illinoisensis................ 90,94-95, 106, 152 var..................... 95-96,152 meliniformis........................ 96 monroensis..................... 96-97,152 sanctiludovici........................ 97 swallowi............................ 94,95 welleriana.................... 93-94, 97, 152 wyomingensis...................... 94 Myalinidæ............................. 92-97 Myoconcha dubia....................... 106 Mytilidæ............................. 107 N.

Naticopsis altonensis . . .................. 121 carleyana........................ 121, 122 deformis............................ 124 dispassa.............................. 125 genevievensis.................... 121-122 howei.............................. 125 littonana var. genevievensis.......... 121,122 nanus............................. 125 splendens........................ 122, 124 Neritopsidæ........................ 121-122

Nucula rectangula......................... 83,156 shumardiana....................... 84

Nuculana nuculæformis................... 86

Nuculidæ............................. 83-84 
o.

Page.

Orbiculoidea batesvillensis

39

Orthoceras aff. eurekense. caneyanum.

128,150

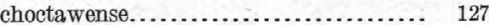
indianum..................... 126,127,150 okawense.......................... 127

Orthoceratidæ....................... 126-128

Orthonychia acutirostre.................. 123

Orthotetes subglobosus.................. 42, 45 subglobosus var. batesvillensis. $42,42-44,45,140$ var. protensa. $44-45,140$

Ostracoda 134-137

P.

Paraparchites carbonaria . 134-135 nicklesi 134-135, 164

Patella levettei............................ 112

Patellidæ ................................. 112

Patellostium branneri.............. 118-119, 164

Pectinidæ............................. 103-106

Pelecypoda........................... 77-111

Penrose, R. A. F., jr., cited ............... 7

Pharkidonotus percarinatus .............. 117

Pholadellidæ........................... 108-110

Pinna arkansana........................ 87

Pinnidæ............................ 87-88

Plagioglypta venusta....................... 111

Plant remains, occurrence of............... 15

Platyceras acutirostre .................. 123-124 circularis ............................ 112 parvum.............................. 124 uncum........................... 123

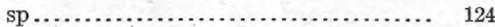

Pleurophoridæ.................... 110-111

Pleurotomaria aff. perhumerosa....... 113-114, 164 arkansana .......................... 113, 164 inornata........................... 113 subglobosa........................ 114 sp .................................... 114

Pleurotomariidæ...................... 113-116

Polypora sp........................... 37

Primitia fayettevillensis.................... 135 seminalis ............................ 135

Productella dissimilis . .................. 55-56 hirsutiformis ...................... 45, 142

Productidæ.......................... 45-59

Productus, abundant in Marshall area...... $\quad 16$ adairensis......................... 50,144 arkansanus..................... 46, 47,142 boliviensis.......................... 47 capacii............................... 55 cestriensis........................... 59 cora................................ 48 coræformis ......................... 48 dissimilis .......................... 51,55 elegans............................. 58,59 fasciculatus.................. 56, 57-58,59 flexistria............................. 58 inflatus............................ 47

var. coloradoensis............... $47-48$ lasallensis ............................. 55 longispinus.......................... 55 pileiformis......................... 48-50 splendens.
Productus tenuicostatiformis wabashensis

Proetidæ............................. 133-134

Protocycloceras sp.................... 128

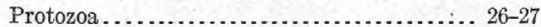

Pteriidæ................................ 91-92

Pterineidæ............................. $88-90$

Pteronites hopkinsi...................... 91

levis ............................. 91,96

spergenensis......................... 89

Pugnax mutata......................... 60

Pyramidellidæ.......................... 125-126

R.

Ramsey ferry, collection from .............. 8

Register of localities...................... 138

Reticularia pseudolineata............... 65,66 setigera......................... $65-66,146$

Retzia radialis............................ 75

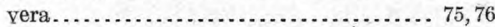

vera var. costata...................... 75

verneuilana......................... 75,76

Rhopalonaria sp...................... 38,164

Rhopalonariidæ........................ 38

Rhynchonella mutata................... 60

Rhynchonellidæ....................... 59-61

Rosiclare sandstone, suggested correlation of, with Batesville sandstone........ 18-19

Rotaliidæ........................... 27

Round Mountains, collection near.......... 10

\section{$\mathrm{S}$.}

Ste. Genevieve limestone, suggested correlation of, with Batesville sandstone 17-25

Sanguinolites multistriatus................. 87

Scaphopoda.......................... 111-112

Schizodus arkansanus............... 101,101-102

batesvillensis ............ 97-98, 101,102,160

brannerianus................ 100-101,102,160

chesterensis....................... 100,102

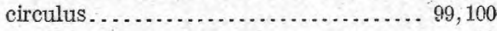

depressus............................... 99

var. abruptus . . . . . . . . . . . . . . 99-100, 160

var. circulus...................... 100,160

meekanus........................... 102

ovatus................................... 101

perelegans............................ 102

wheeleri............................. 102

Schuchertella williamsi.............. 40-42, 43, 142

Seminula subquadrata.................. 72,73

Solenocheilidx.......................... 129

Solenocheilus sp........................ 129

Solenopsidæ.......................... 77-81

Spergen limestone, fossils in............... 20-23

Sphærodoma littonana var. genevievensis.. 121,122

Sphenotus æolus....................... $\quad 78$

aff. branneri.......................... $78-79$

aff. meslerianus................... 80-81, 156

bicostatus........................... 81

constrictus........................ $79,80,156$

contractus ......................... 78

cultellus........................ $79-80,156$

cylindrica.......................... 78

dubia............................... $\quad 78$

(Pleurophorus) monroensis............ 111

naiadiformis.......................... 79 


\begin{tabular}{|c|c|}
\hline Page: & Page. \\
\hline phenotus nobilis . & Sulcatipinna arkansana... \\
\hline obliquus.... & inexpectans. \\
\hline inolites) retusus................ 111 & maxvillensis. \\
\hline 111 & \\
\hline salteri............... & abillinora \\
\hline signatus... & - $30-31$ \\
\hline$\ldots$ & \\
\hline valvulus... & miseri........... \\
\hline vulgaris........... & Terebratula marcyi.. \\
\hline washingtonensis... & insulcat \\
\hline spirifer increbescens. ......... & 70 \\
\hline uk. ............................... 64,65 & Terebratulidæ... \\
\hline 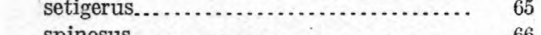 & Trigoniidæ............ \\
\hline 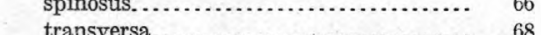 & Trilobita............................. 1334 \\
\hline ans & Trochammina annularis .................. \\
\hline (1, & dialis. \\
\hline 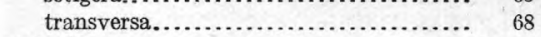 & 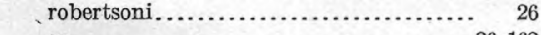 \\
\hline 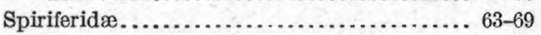 & 6,162 \\
\hline d to Batesville area ........ & U. \\
\hline cristata........................ 66,67 & Ulrich, E. O., cited........... \\
\hline (n)................ & 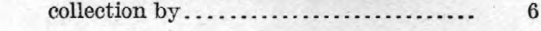 \\
\hline kentuckyensis.......................... & \\
\hline$\ldots \ldots 66-68,146$ & \\
\hline …. $67,68-69,146$ & Vertebrate fossils, occurrence of......... \\
\hline Spirigera americana.......... & W \\
\hline 70,71 & Waagen, w., cited............. \\
\hline$\cdots$ & Walker Museum, acknowledgment to......... \\
\hline 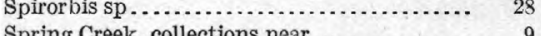 & Weller, Stuart, acknowledgments to... $6,39,40,108$ \\
\hline 120 & cited \\
\hline ............ & of Batesville fa \\
\hline hus ulrichi..................... & $\mathbf{Y}$ \\
\hline$\ldots \ldots \ldots \ldots \ldots$ & Yoldia levistriata.. \\
\hline Strophomenidæ............. & \\
\hline lus aff. carleyanus & \\
\hline & 27 \\
\hline 125,1 & 27 \\
\hline
\end{tabular}

